\title{
Toward understanding the dynamics of land change in Latin America: potential utility of a resilience approach for building archetypes of land- systems change
}

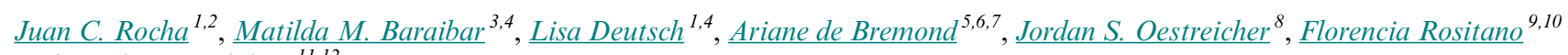 \\ and Cecilia C. Gelabert ${ }^{11,12}$
}

\begin{abstract}
Climate change, financial shocks, and fluctuations in international trade are some of the reasons why resilience is increasingly invoked in discussions about land-use policy. However, resilience assessments come with the challenge of operationalization, upscaling their conclusions while considering the context-specific nature of land-use dynamics and the common lack of long-term data. We revisit the approach of system archetypes for identifying resilience surrogates and apply it to land-use systems using seven case studies spread across Latin America. The approach relies on expert knowledge and literature-based characterizations of key processes and patterns of land-use change synthesized in a data template. These narrative accounts are then used to guide development of causal networks, from which potential surrogates for resilience are identified. This initial test of the method shows that deforestation, international trade, technological improvements, and conservation initiatives are key drivers of land-use change, and that rural migration, leasing and land pricing, conflicts in property rights, and international spillovers are common causal pathways that underlie land-use transitions. Our study demonstrates how archetypes can help to differentiate what is generic from context dependant. They help identify common causal pathways and leverage points across cases to further elucidate how policies work and where, as well as what policy lessons might transfer across heterogeneous settings.
\end{abstract}

Key Words: archetypes; land-use change; Latin America; regime shifts; resilience assessment

\section{INTRODUCTION}

Latin America has experienced faster agricultural expansion than any other world region in the past two decades, mostly at the expense of tropical forests (Gibbs et al. 2010). At the same time, the region is also identified as holding the largest potential area available for further agricultural expansion globally (Lambin et al. 2013, Graesser et al. 2015, MacDonald et al. 2015). Together these factors point to a future in which the region continues to play a pivotal role in global food production and exports. Although Latin America's rural areas are some of our planet's most biodiverse (Kuemmerle et al. 2017), they are also characterized by contested and weak property rights to land. The pace of land-use change has intensified environmental conflict across the region in recent decades, heightening concerns about environmental sustainability and social desirability of such changes (de Castro et al. 2016). Amidst such land use and livelihood transformations, Latin American countries have committed to achieving the 17 sustainable development goals (SDGs) of the UN Agenda 2030 (UN General Assembly 2015). Meeting these goals requires planning for resilient landscapes that can support inclusive economic development and the provisioning of nature's benefits to people, while coping with changes in climate alongside growing demand for land and its products (Flachsbarth et al. 2015).

Resilience is the ability of any system to maintain its function and structure in the face of change, and for this it depends on its ability to learn, adapt, and transform (Folke 2016). Resilience analysis can inform us how difficult it is to shift a system from one configuration (regime) to another; e.g., to adopt a certification program that changes the function and structure of the landscape. Regime shifts are large, abrupt, and persistent critical transitions in the function and structure of social-ecological systems (Scheffer et al. 2001, Folke et al. 2004). They are a useful conceptualization to study land-use and land-cover change because they acknowledge the role of nonlinearities, in other words, the existence of feedbacks (Müller et al. 2014, Ramankutty and Coomes 2016). Although all land-use changes are not regime shifts, land-use change processes exhibit feedback dynamics that can be hard to reverse; making regime shifts a conceptual framework tailored to capture land-use change dynamics. In this context, a regime is a structural configuration of the landscape that reflects both the function and structure of the socialecological system (e.g., a forest, a silvo-pastoral system, or a soy plantation). Thus, the resilience of a system also indicates how difficult is it to reverse a regime shift once it has occurred. For example, if a subsidy scheme is implemented that promotes the transformation from forest to an agricultural landscape, resilience is related to the probability that the forest will recover if the subsidy is removed. If the removal of the subsidy does not "flip" the system back (i.e., the shift is hard to reverse), then the system is said to exhibit hysteresis, meaning there are new social and ecological feedbacks in place maintaining the agricultural

\footnotetext{
${ }^{1}$ Stockholm Resilience Centre, Stockholm University, ${ }^{2}$ Beijer Institute of Ecological Economics, Swedish Royal Academy of Science, ${ }^{3}$ Department of Economic History and International Relations, Stockholm University, ${ }^{4}$ Institute of Latin American Studies, Stockholm University, ${ }^{5}$ Centre for Development and Environment, University of Bern, ${ }^{6}$ International Programme Office, Global Land Programme, ${ }^{7}$ University of Maryland, College Park, ${ }^{8}$ Universidade de Brasília, Centro de Desenvolvimento Sustentável, ${ }^{9}$ Universidad de Buenos Aires, Facultad de Agronomía, Departamento de Producción Vegetal, Cátedra de Cerealicultura, Buenos Aires, Argentina, ${ }^{10}$ CONICET, Universidad de Buenos Aires, IFEVA, Buenos Aires, Argentina, ${ }^{11}$ Universidad de Buenos Aires, Facultad de Agronomía, Departamento de Economía, Desarrollo y Planeamiento Agrícola, Cátedra de Sistemas Agroalimentarios, Buenos Aires, Argentina, ${ }^{12}$ Universidad Nacional de Misiones, Facultad de Ciencias Forestales, Área de Producción vegetal con énfasis en sistemas agroalimentarios sustentables, Eldorado, Misiones, Argentina
} 
landscape. To avoid regime shifts or improve capacity for transformation toward desirable systems, resilience analysis is a useful approach. Using simple models operationalized in qualitative causal loop diagrams, we aim to map and study systems to identify drivers, pathways, and leverage points: in other words, system archetypes (Bennett et al. 2005).

We operationalize resilience analysis in the context of land-use change through case study comparison and the identification of systems archetypes. Operationalizing resilience has proven a challenge in large scale contexts because existing methods tend to impose high data demands (both spatio-temporal and socioeconomic), although most resilience assessments limit themselves to participatory consultations that do not necessarily scale up (Resilience Alliance 2011, Dakos et al. 2015). Reconciling context dependent features with common regional drivers and trends remains a challenge in sustainability science (Ostrom 2007, 2009), especially in regions with heterogeneous, contentious, and highly dynamic land-use change such as Latin America. To address these challenges, we revisit the approach of resilience surrogates by mapping systems archetypes: causal network representations of the system's structure and function (Bennett et al. 2005). Archetypes are a formal way of classifying minimal feedback structures responsible for generic dynamical patterns, key drivers, feedbacks, and leverage points (Senge 1991, Wolstenholme 2003, Meadows and Wright 2008). An archetype is a network of interrelations that can lead either to (1) the mutual stabilization of a cluster of trends, therefore generating persistent dynamics (the regimes), or (2) the mutual amplification of a cluster of trends, potentially leading to rapid and drastic changes (the shifts; Eisenack 2014). Recent work has shown that some challenges of operationalization can be overcome through the creation of a database of case studies of land-use change (Ramankutty and Coomes 2016). We aim to set foundations for such a database, adapting the comparative framework developed for the regime shifts database (Biggs et al. 2018) to integrate more socially driven dynamics. The regime shifts database has allowed the creation of a consistent framework to systematically analyze impacts, key drivers, underlying feedbacks, and management options, as well as facilitating comparison between multiple regime shifts. The framework, however, does not target social dynamics such as trade, or the role of public policies on (de) stabilizing regimes. We modify this approach through the development of a new template extending the archetype mapping to social and economic drivers and feedbacks of land-use and land-cover change. In this way, we intend to facilitate future endeavors to upscale resilience analysis and provide a step forward in distinguishing what is generalizable from what is context dependent in social-ecological systems research (Magliocca et al. 2018).

\section{CONCEPTS AND METHODS}

Resilience thinking is an analytical approach focusing on stabilizing and destabilizing processes and implies attention to slow variables and feedback processes (Bennett et al. 2005, Biggs et al. 2012). To address these aspects of social-ecological systems we employ systems archetypes. If resilience is the ability to maintain function and structure (Folke 2016), and regime shifts are abrupt, persistent changes in the structure and function of systems (Scheffer et al. 2001), then an archetype is a simplification of that structure.
Archetypes have been treated in the literature as both the structure of variables that produce trends (the equations or causal hypotheses) and the trends themselves, i.e., observables whose change over time can be measured (the dynamic behavior; Wolstenholme 2004). Empirically, such trends can be observed and measured, and their clustering can be identified using multivariate statistical methods (Rocha et. al nonreviewed preprint). For example, Václavík et al. (2013) and Levers et al. (2018) explicitly labeled their data-driven work as land systems archetypes, whereas others have produced similar land classification schemes of land use based on an empirical approach (Ellis and Ramankutty 2008, van Asselen and Verburg 2012, Letourneau et al. 2012, Václavík et al. 2013, Levers et al. 2018). Oberlack et al. (2016) defined archetypes as recurrent patterns that explain how configurations of factors generate an outcome by activating processes of social-ecological interaction. If the recurrent network of interrelations or causal mechanisms cannot be observed, then it becomes necessary to develop models that capture these reappearing patterns of causal interaction. We operationalized analysis of resilience by discerning archetypes that capture both the trends (dynamics) and the structures (causal hypotheses) that produce the trends. We identify archetypes in a qualitative fashion, capturing changes in land use over time in different case studies (Table 1) through literature reviews and expert elicitation. We employed a data template inspired by the regime shifts database that focused our attention on slow variables, feedback processes, and drivers of change. Once the data template is completed, experts evaluate the causal structure of the system enabling the development of causal-loop diagrams (CLDs). Both the trends captured and the causal hypotheses developed are the archetypes operationalized to study resilience.

\section{Data template and case studies}

Building on the experience of the regime shifts database framework (Biggs et al. 2018), we developed a template (Appendix 1) for systematically collecting literature-based and expertknowledge synthetic insights from case studies on land use/cover change. The template substantially reduces complexity from the original source and is designed to facilitate data collection from people without a background in regime shifts, but with extensive expertise on the specific patterns, trends, and drivers involved in particular cases of land-use change. The template includes a text document with semiopen questions and predefined categorical variables, as well as two tables that aim to capture drivers, feedback mechanisms, and the desirability of change by different stakeholders (Appendix 1, 2).

This paper arose from the workshop "Seeking sustainable pathways for land use change" organized by the South American Institute of Resilience and Sustainability Studies (http://sarasinstitute.org) in Uruguay, March 2016, during which a regionally, and topically, diverse group of scholars came together with practitioners and regional government representatives to conceptualize recent land-use change in Latin America. As an outcome of the conference, seven case studies were identified (Table 1, Fig. 1). The criteria for including case studies was the availability of published evidence of an ongoing shift in land-use change in any country in Latin America in which a field expert with deep case knowledge could provide validation. To assure capture of the appropriate elements, and given that the template was a time-consuming iterative experiment to better capture 
Table 1. Case studies.

\begin{tabular}{|c|c|c|c|c|c|}
\hline Case & Place & Area $\left(\mathrm{Km}^{2}\right)$ & Period $\dagger$ & Thematic focus & Land use \\
\hline $\begin{array}{l}\text { Eco-certification of } \\
\text { coffee in Santander, } \\
\text { Colombia }\end{array}$ & $\begin{array}{l}\text { Suarez River, } \\
\text { Santander, Colombia }\end{array}$ & 1000 & 2003-2010 & $\begin{array}{l}\text { Land-use/cover change, } \\
\text { agricultural practices, } \\
\text { rural economic changes }\end{array}$ & Small-scale crops \\
\hline $\begin{array}{l}\text { Cattle ranching } \\
\text { expansion and } \\
\text { deforestation in } \\
\text { Paraguayan Chaco }\end{array}$ & $\begin{array}{l}\text { Boqueron Alto and } \\
\text { Presidente Hayes, } \\
\text { Paraguay }\end{array}$ & 500,000 & 2002-2016 & $\begin{array}{l}\text { Land-use/cover change, } \\
\text { ecosystem services } \\
\text { provision, biodiversity } \\
\text { change }\end{array}$ & Extensive livestock \\
\hline $\begin{array}{l}\text { Soybean agribusiness } \\
\text { expansion in the } \\
\text { Litoral region, } \\
\text { Uruguay. }\end{array}$ & $\begin{array}{l}\text { Litoral region, } \\
\text { Uruguay }\end{array}$ & 10,000 & 2000-2015 & $\begin{array}{l}\text { Land-use/cover change, } \\
\text { agricultural practices, } \\
\text { rural economic changes }\end{array}$ & $\begin{array}{l}\text { Large-scale crops, } \\
\text { extensive livestock }\end{array}$ \\
\hline $\begin{array}{l}\text { Land concentration } \\
\text { and ecosystem services } \\
\text { in Pampean } \\
\text { agroecosystems, } \\
\text { Argentina }\end{array}$ & $\begin{array}{l}\text { Pampas region, } \\
\text { Argentina }\end{array}$ & 100,000 & 2000-2010 & $\begin{array}{l}\text { Ecosystem services } \\
\text { provision, agricultural } \\
\text { practices, rural } \\
\text { economic change }\end{array}$ & Large-scale crops \\
\hline $\begin{array}{l}\text { Expansion of small- } \\
\text { scale agriculture and } \\
\text { ranching, Pará, Brazil }\end{array}$ & $\begin{array}{l}\text { Municipalities of } \\
\text { Aveiro and Rurópolis, } \\
\text { Pará, Brazil }\end{array}$ & 1000 & 1990-2008 & $\begin{array}{l}\text { Ecosystem services } \\
\text { provision, health }\end{array}$ & Small-scale crops \\
\hline $\begin{array}{l}\text { Rural out-migration } \\
\text { and farm abandonment } \\
\text { in the Pará, Brazil }\end{array}$ & $\begin{array}{l}\text { Novo Caminho } \\
\text { community, Pará, } \\
\text { Brazil }\end{array}$ & 100 & 2008-2015 & $\begin{array}{l}\text { Rural out-migration, } \\
\text { forest transition }\end{array}$ & Small-scale ranching \\
\hline $\begin{array}{l}\text { Forest resurgence in } \\
\text { postwar El Salvador }\end{array}$ & $\begin{array}{l}\text { Municipality of } \\
\text { Cinquera Cabañas, El } \\
\text { Salvador }\end{array}$ & 100 & 1992-2006 & $\begin{array}{l}\text { Land-use/cover change, } \\
\text { civil conflict, forest } \\
\text { resurgence/transition }\end{array}$ & $\begin{array}{l}\text { Small-scale crops, } \\
\text { semiwild ecosystems } \\
\text { (conservation/tourism) }\end{array}$ \\
\hline
\end{tabular}

socially driven regime shifts in land-use systems, experts also provided feedback on the template design. Our small sample size is explained by two factors: first, we endeavored to test this method as a conceptual tool for operationalizing archetypes analysis and not to perform an exhaustive analysis capturing all possible archetypes; and second, the selection of cases required the participation of an identified expert to fill and review the template and complete the causal network interpretation.

\section{Archetypes as causal networks}

Causal-loop diagrams (CLDs) are maps of the feedback structure of a system and a tool for communicating causal hypotheses to broader audiences (Sterman 2000). Variables are connected by arrows denoting causal influence. A link is positive if a change in the origin variable produces a change in the same direction on the response variable, whereas a negative link denotes a relationship characterized by the opposite direction. This notation is structural, meaning that it only denotes what one would expect to happen when all else is constant. Feedback loops appear when a chain of causal relationships form a directed cycle, tracing a pathway that starts and ends with the same variable. These structures are important because they determine the amplification or dampening of dynamic processes that underlie nonlinearities of the system (Sterman 2000). Archetypes have been thought of as basic building blocks of minimal feedback structures that can give rise to any observed dynamic (Sterman 2000, Wolstenholme 2003). Figure 1 shows an example of the CLD developed for the certified coffee case study in Colombia.

Causal diagrams are by definition an incomplete depiction of the system (Sterman 2000). Our CLDs are limited by the perceptions of the experts and bounded by the variables reported in the published literature. For example, Figure 1 does not report climate change to be a relevant variable on the case study, because neither the expert nor the literature reviewed report climate as an underlying variable of change. It does not mean climate is not an important factor for the case study, it means that it has not been reported on. The underlying assumption is that the CLD coder only translates what others have described as relevant processes: the expert, the literature, and both are verifiable through the template. The coder should not include his/her own hypothetical thinking if it is not backed up by the literature or expert. This methodological assumption is inherited from the regime shifts database in which only causal hypotheses that can be traced back to scientific publications are reported (Biggs et al. 2018). We have relaxed that assumption to include the knowledge of experts.

Structural equivalence is a method that allows us to identify nodes that play similar roles in a network (Newman 2009), thus identifying archetypical variables that belong to common structures. We studied the structural equivalence of the variables (called nodes) in these networks by looking at the similarity of their positions (who is connected to whom), as well as their similarity across cases. To find structural equivalence, we joined all causal networks in a unique matrix and measured the Euclidean distance of all variables in the directed graph, as well as the Jaccard distance on the bipartite graph (the network of variables in the CLD and to which case they belong to). With these distances, we approximated structural equivalence with hierarchical clustering to group similar nodes according to their number of connections, i.e., degree centrality, in the combined network of CLDs, or the cases they belong to. Our analysis was 
Fig. 1. Case studies and causal-loop diagram (CLD example). Left: causal-loop diagram for the eco-certified coffee case study. Blue arrows denote positive relationships, orange arrows negative relationships. Variables in yellow belong to feedbacks whereas variables in gray are outside feedbacks; hence by definition they are external drivers: their dynamic behavior does not depend on the state variables of the system. Right: map with case studies. Circle size is proportional (in log-scale) to the area that the case study describes. The inset shows the temporal horizon at which each case study is described. For details on summary categorical variables from the template see Table 1, and a summarizing description of each case study see Table 2. Geographic information was obtained from Google Maps API.

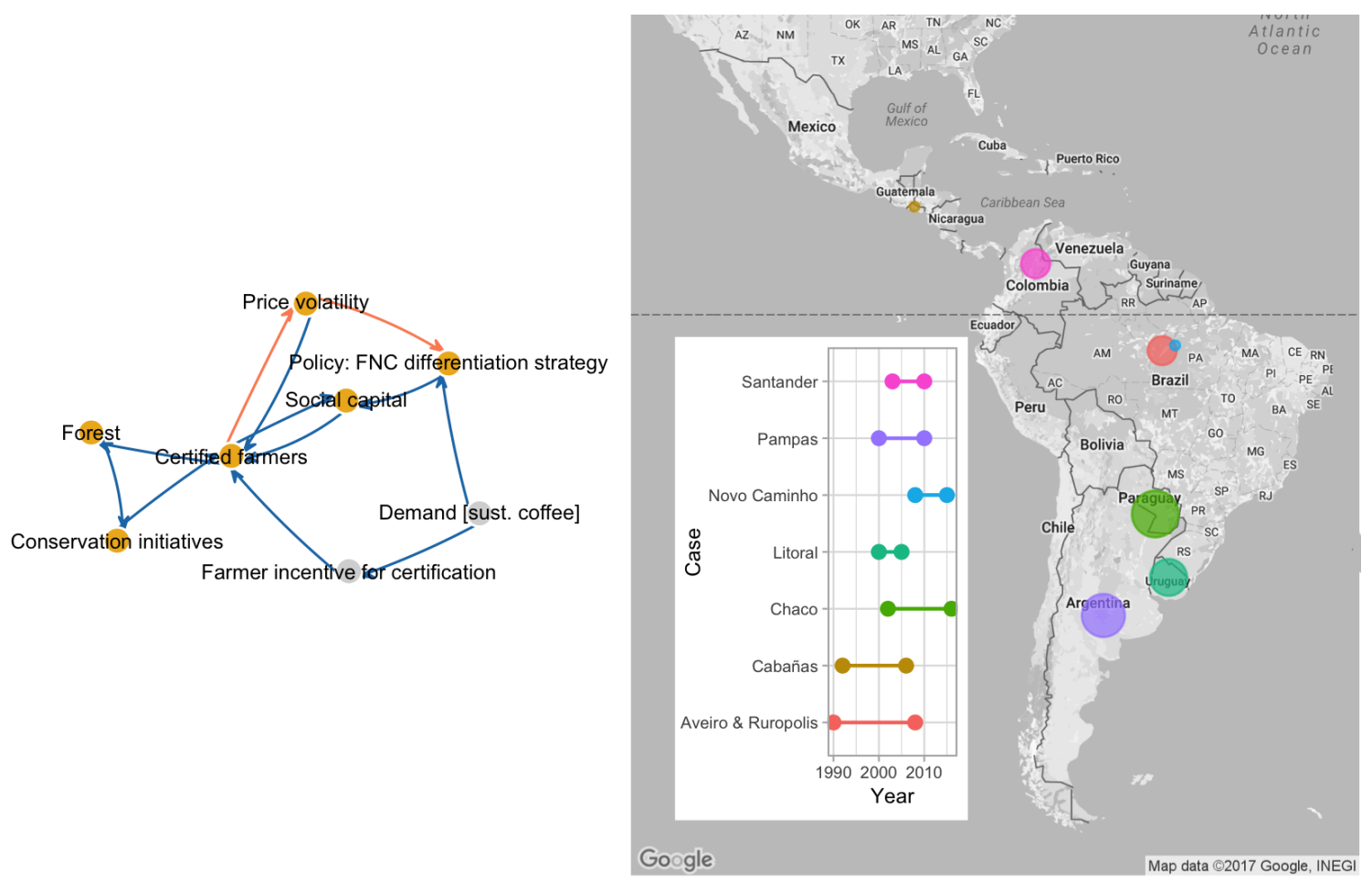

performed in the $\mathrm{R}$ statistical computing environment ( $\mathrm{R}$ Core Team 2017) using the Statnet suit of packages (Handcock et al. 2008).

\section{RESULTS}

We describe and compare archetypical causal structures, common trends, drivers, and differences across cases and observed leverage points in all cases. Further details on case studies are summarized in Table 2 and respective CLDs in Figure 2, both derived from the completed templates (available in Appendix 1).

\section{Causal structures}

Combining all seven case studies into a single composed network shows 96 variables connected through 191 links, of which $10 \%$ of links occur in more than one case (Fig. 2a). The most similar cases in terms of common links are Pampas (Argentina) and Litoral (Uruguay), both related to the expansion of soy and a shift from small-scale, relatively low intensity practices to large, high-input operations. The cases in Chaco (Paraguay) and Aveiro/Ruropolis (Brazil) share the link between deforestation and forest cover, whereas the links between grassland area and cattle ranching are common to Chaco and Litoral. The most central variables, as defined by number of connections, are soy cropland, cattle ranching, small-scale producers, and forest (Fig. 3). Similarly, the variables that appear in most cases are rural out-migration and forest (five cases), cattle ranching, deforestation, land prices, and population growth (three cases). Further structural analysis shows that these variables form clusters across cases (with maximum co-occurrence of three out of our seven cases, columns in Fig. 3), as well as clusters of well-connected variables in the causal networks given their numbers of connections (rows in Fig. 3). Drivers and leverage points (policies) tend to have low centrality by both measures and, as expected, tend to lie on the periphery of the causal networks (Liu and Barabasi 2015). Although variables could be grouped under common categories (e.g., policies, commodity demand, commodity prices), the variable names correspond to specific features of cases that are not comparable within the network (e.g., price of gold or soybeans). However, the results point out commonalities that result in differing causal effects (Meyfroidt et al. 2016) from place to place. Such common features highlight the role of international trade, demand for foods, commodity prices, technological improvements, and national policies. 
Table 2. Case studies summary descriptions. Only key references have been included in the table. The full list of references consulted to describe each case study is available on the case study template (Appendix 1).

\begin{tabular}{l}
\hline \hline Case and key references ${ }^{\dagger}$ \\
Eco-certification of coffee in Santander, \\
Colombia \\
Describes the shift from traditional coffee \\
production to eco-certified coffee.
\end{tabular}

Rueda et al. $2013 a, b, 2015$

Cattle ranching expansion and deforestation in Paraguayan Chaco

Exemplifies the shift from forest to rangelands for cattle production in Paraguay.

Jobbágy et al. 2015, Vallejos et al. 2015, le Polain de Waroux 2016

Soybean agribusiness expansion in the Litoral region, Uruguay

This case describes the shift from grasslands to soybean plantations.

Arbeletche et al. 2012, Baraibar 2014, Gelabert et al. 2017

Land concentration and ecosystem services in Pampean agroecosystems, Argentina

This case study describes a change in ecosystem services appropriation in Argentina.

Rositano and Ferraro 2014, Rositano et al. 2018

Expansion of small-scale agriculture and ranching, Pará, Brazil

This case describes the emergence of disease driven by deforestation and land-use change

Myers and Patz 2009, Rozon et al. 2015, Oestreicher et al. 2014, 2018

\section{Description}

The case is based on the assessment of whether the use of eco-certification for agricultural commodities actually reflects in observable significant changes in the rural landscapes and the well-being of rural households. The case takes place in the Upper Suárez river watershed, in the eastern Colombian Andes. Based on satellite imagery and geo-referenced farm information, the authors provide insights to understand why farmers join and stay in certification programs, going beyond the expected monetary benefits. Certification by small-holder farmers is seen as an adaptation to the global coffee market that demands more sustainably produced products. The transmission of value from environmentally minded consumers to farmers though the value-chain has effectively lead to forest cover increase and other environmental outcomes driven by certification. Certified farmers might not always get a premium price for the coffee, but the certified scheme does provide a buffer to the international price volatility of coffee. Certification schemes increase the probability of the conservation of small forest areas within farms and biodiversity conservation.

Soy expansion in neighboring countries has caused deforestation in El Chaco to increase cattle ranching. Soy expansion in Brazil, Uruguay, and Argentina has pushed cattle ranchers to relocate in less suitable areas for soy production, but where land prices, labor, and taxes are lower than their original productive grounds. As a result, many ranchers have moved to the Western Paraguayan Chaco, part of Gran Chaco plains, an area of over 647,000 $\mathrm{km}^{2}$ shared between Argentina, Paraguay, Bolivia, and a small area of Brazil. Deforestation in the Paraguayan Chaco accounts for the shift from forest to grasslands of $62 \%$ of the 0.8 million ha of new pasturelands from 2001 to 2013. In 2014 alone, 287,000 ha of Chaco forest were lost, and the cumulative loss since the year 2000 is 5.5 million ha equivalent to a loss of $\sim 20 \%$ of the forest. Deforestation in the Paraguayan Chaco has been driven by international demand for beef and its prices, as the majority of Paraguayan cattle/beef production is exported, but also by lower production costs in this area than in neighboring countries. The rapid development of cattle ranching in the area has more than doubled livestock production in less than 15 years, resulting in landscape fragmentation and degradation of important ecosystem functions (such as carbon sequestration), as well as land rights conflict with indigenous groups. The expansion of cattle ranching and growth of the beef production industry is expected to continue. Located in the litoral region of Uruguay, this case study describes land-use change from the year 2000 to the 2015 , in which the production of both crops and livestock have been intensified. In particular, soybeans have had a spectacular growth from almost nonexistent to the number one crop (the area planted is 1.2 million ha), in a context of commodity prices at record highs, driven largely by increased demand from China for meat (soybeans for animal feed), and new technologies. This has created accelerated competition for land, a drastic reduction of the areas under pasture, a general intensification with stronger pressures on natural resources, as well as increased owner concentration under the dominance of new agribusiness actors. In particular, the expansion and risk diversification strategies of Argentinean firms resulted in their dominance of $35 \%$ of the cropland area in Uruguay. Uruguayan public policies have for the past decades supported this expansion by using fiscal incentives to stimulate investments, liberalizing trade, and allowing for genetically modified varieties. Today, soybean related products account for $16 \%$ of Uruguay's total exports as opposed to $\sim 1 \%$ at the beginning of the century. However, intensification, less rotation, and expansion into more marginal lands increased soil erosion. Consequently, since 2013, a national conservation policy made it mandatory to submit a natural resources management and soil-use plan to the Ministry of Agriculture, which is expected to make producers balance soybeans with other grain or oilseed crops and pastures to mitigate erosion risk.

Argentinean Pampas region is a plain with fertile soils characterized by grasslands. The region has also experienced an expansion and technification of agriculture, with a strong focus on soybeans. While soy crops have expanded, crop rotations and crop/livestock rotations have decreased. Decisions on how to manage the land are being concentrated in fewer landowners; 4 million ha belong to 116 owners approximately. Between 1998-2002, 87,000 farms have disappeared, which represents $25 \%$ of national farms, whereas rural population has decreased by $8.3 \%$. These changes in land use and land cover are thought to be driven by high international soy prices, as well as different agricultural practices such as land leasing and participation in futures markets. This area is a supplier of ecosystem services linked to food production and economic income. Rositano and Ferraro (2014) studied the functional relationships between agricultural management and ecosystem services provision in this region and found that the soil nitrogen balance was negatively affected in 10 growing seasons (2000-2010).

In the municipalities of Aveiro and Rurópolis in Pará state, the rural population nearly doubled in the early 1990 s as migrant workers took up homesteading in place of gold mining after the decline in international gold prices and the closure of local mines. Rural land claims and agrarian development were supported by already established institutional and legal frameworks aiming to integrate the remote region into the national economy, notably through infrastructural expansion projects, land reform, and agrarian credit programs. Over the next two decades, agriculture encroached on tropical forests as newly settled families transitioned from subsistence livelihoods to cash crop production, with many farmers eventually diversifying to include ranching. Financial capital, new seed and livestock varieties, chemical inputs, and national markets became increasingly accessible to rural smallholders. By 2008 , over half of the region's primary forests had been deforested, owing to the cumulative effects of small-scale farming. Deforestation and land degradation alter key ecosystem processes related to human health, including the cycling of biogeochemicals and disease vectors/pathogens in the environment. In the Tapajós region, mercury exposure and Chagas disease transmission are two health risks associated with land-use change, primarily affecting poor rural farmers and fishers. 
Rural out-migration and farm abandonment in the Pará, Brazil

Rudel et al. 2011, Parry et al. 2010, Almeida et al. 2016

Forest resurgence in postwar El Salvador

This case describes the shift from war to peace and the forest recovery that emerged from conservation bottom-up initiatives.

de Bremond 2006, 2008, Valencia et al. 2012
In the community of Novo Caminho (municipality of Aveiro, Pará state), demographic and land-use dynamics have recently shifted toward rural out-migration and forest regrowth. Between 2008 and 2012, the population dropped by $77 \%$, with mostly women and youth migrating to growing cities or urbanizing towns along commodity export corridors. By 2015, the local school and church had closed and most crops and pastures had been abandoned, leading to a near-zero deforestation rate and a threefold increase in secondary vegetation on farms in just a few years. This situation arises from combination of factors, namely the introduction of new social policies, ecosystem degradation, and the emergence of alternative livelihood options. The implementation of the bolsa familia (a conditional cash transfer program) has been a key driver of out-migration. For many rural households it provides a more secure income source compared to subsistence farming especially because the viability of family farming has been affected by increasing pest outbreaks, depleting soil nutrients, and changing seasonal climate. However, bolsa payment requires regular school attendance, child immunizations, and financial services that are sometimes only accessible in cities, which has incentivized out-migration. At the same time, new off-farm employment options in urban areas and the growing demand for seasonal wage labor on soybean farms offer relatively lucrative alternatives to family farming. Current research is underway, examining how changing social network structures in Novo Caminho are linked to rural-urban migration and forest transitions.

The case takes place in the Alto Lempa region, municipality of Cinquera, Cabañas, in which the maintenance and protection of regenerated secondary forests has taken place since 1992 to the present. A forest transition was brought about by cessation of cultivation of these lands during the Salvadoran civil war 1980-1992. Outmigration during the war favored forest regrowth but the area has been inhabited now for 25 years since the armed conflict and has essentially maintained its extension reflecting the successful strategy of the organized local population to conserve the forests. Following the end of the war, communities of excombatants and returning refugees resettled these forested areas but renegotiated their land rights with land agencies and international donors to create and manage a private protected conservation area. In addition to the civil war, forest regeneration resulting from reduced pressure on forests across El Salvador is believed to be attributed to other socioeconomic changes including: a sharp drop in agro-export production between 1970 and 2000 , from $80 \%$ to $11 \%$ of foreign revenue and emigration (beginning with the civil war but continuing afterward) with approximately $20 \%$ of households receiving remittances in 2013 . New policies including a new forestry law with a role for comanagement (brought about partially because of lobbying from Cinquera) are facilitating more participatory forms of conservation.

Complete list of references is available on each case study template in Appendix 1.

Fig. 2. Causal-loop diagram (CLD's for case studies). (a) Combination of all case studies together reveals that all case studies share variables forming a giant component. The case studies are: (b) forest resurgence in postwar El Salvador; (c) deforestation in Chaco, Paraguay; (d) certified coffee in Santander, Colombia; (e) land abandonment in Brazilian Amazon; (f) ecosystem services in Pampa, Argentina; (g) expansion of small-scale agriculture in Tapajos River, Brazil; and (h) soybean expansion in Uruguay. Nodes in yellow belong to feedback mechanisms whereas nodes in gray are drivers (variable outside feedbacks when pointing toward feedbacks). Blue links represent positive relationships whereas orange are negative links. Larger versions with labeled variables are available in the supplementary material.

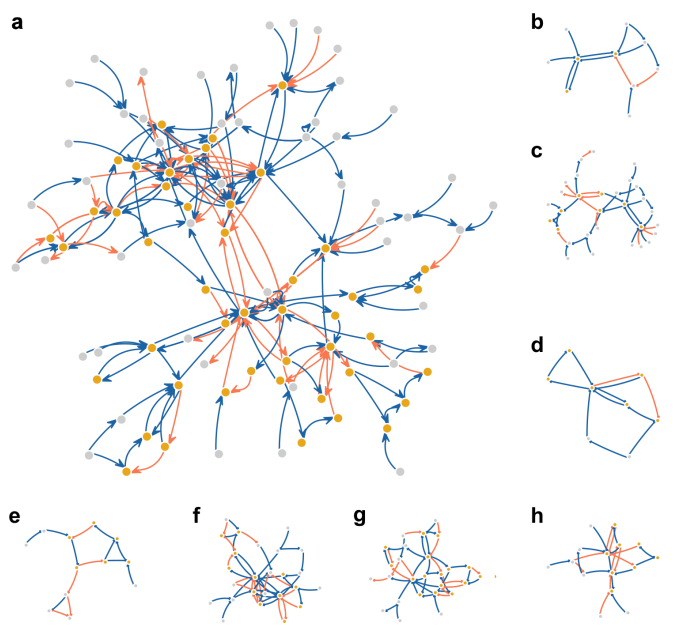

\section{Common trends, drivers, and differences}

One of the primary common trends across cases is the importance of trade and international commodity prices as drivers of landuse change. Soybean price is key for the cases in Uruguay, Argentina, and Paraguay; gold for the case in Brazil; and coffee in Colombia. Indeed, the export profiles for Uruguay, Paraguay, and Argentina, in which trade is a strong driver, indicate that soybean and soy products increased their share of exports between 2000 and 2015 (see Appendix 1, Fig. A1.8). Although our cases deal with subnational levels, their land-use patterns reflect changes in national export structure.

The cases in Santander (Colombia), Cabañas (El Salvador), Novo Caminho (Brazil), and Aveiro/Ruropolis (Brazil) involve family farmers rather than actors in the agro-businesses sector. These cases are smaller in spatial extent, with localized effects at the farm or household level; as such, their influence on national economies are less evident. In Santander, niche market trade plays a role by opening access to international certification schemes that have increased forest cover at the farm scale and reduced vulnerability to price volatility for farmers within the certification program (Rueda and Lambin 2013a, $b$, Rueda et al. 2015). In Aveiro/Ruropolis (Table 1), deforestation and small-scale agricultural encroachment were linked to Chagas disease and mercury intoxication risks, with poor, subsistence farmers being most vulnerable. Here, land-use change was driven by public policies in the form of agrarian credit programs and transportation infrastructure development that allowed farmers to access regional markets and expand and diversify their production. Forest transitions, a regime shift from cropland to secondary forest, were described in the Novo Caminho, 
Fig. 3. Structural equivalence analysis. The causal network for all case studies (Fig. 2a) is here represented in its matrix form. Rows are organized by hierarchical clustering according to the connections in the causal networks; two nodes are similar if they share similar neighboring variables. Columns are organized by hierarchical clustering according to the cases in which the variable is reported; nodes are similar if they occur in the same cases. The number of cases in which a node appears is reported on the horizontal color bar whereas the number of connections in the causal networks is reported on the vertical color bar. The maximum number of cases in which a particular link occurs is three. Following the color scheme of Figure 2, links are blue if positive or orange if negative. Variable names are depicted in gray if they are drivers, blue if they appear in a feedback cycle, or pink if they are a leverage point. Note: FNC is the (Spanish) abbreviation for the national association of coffee producers of Colombia.

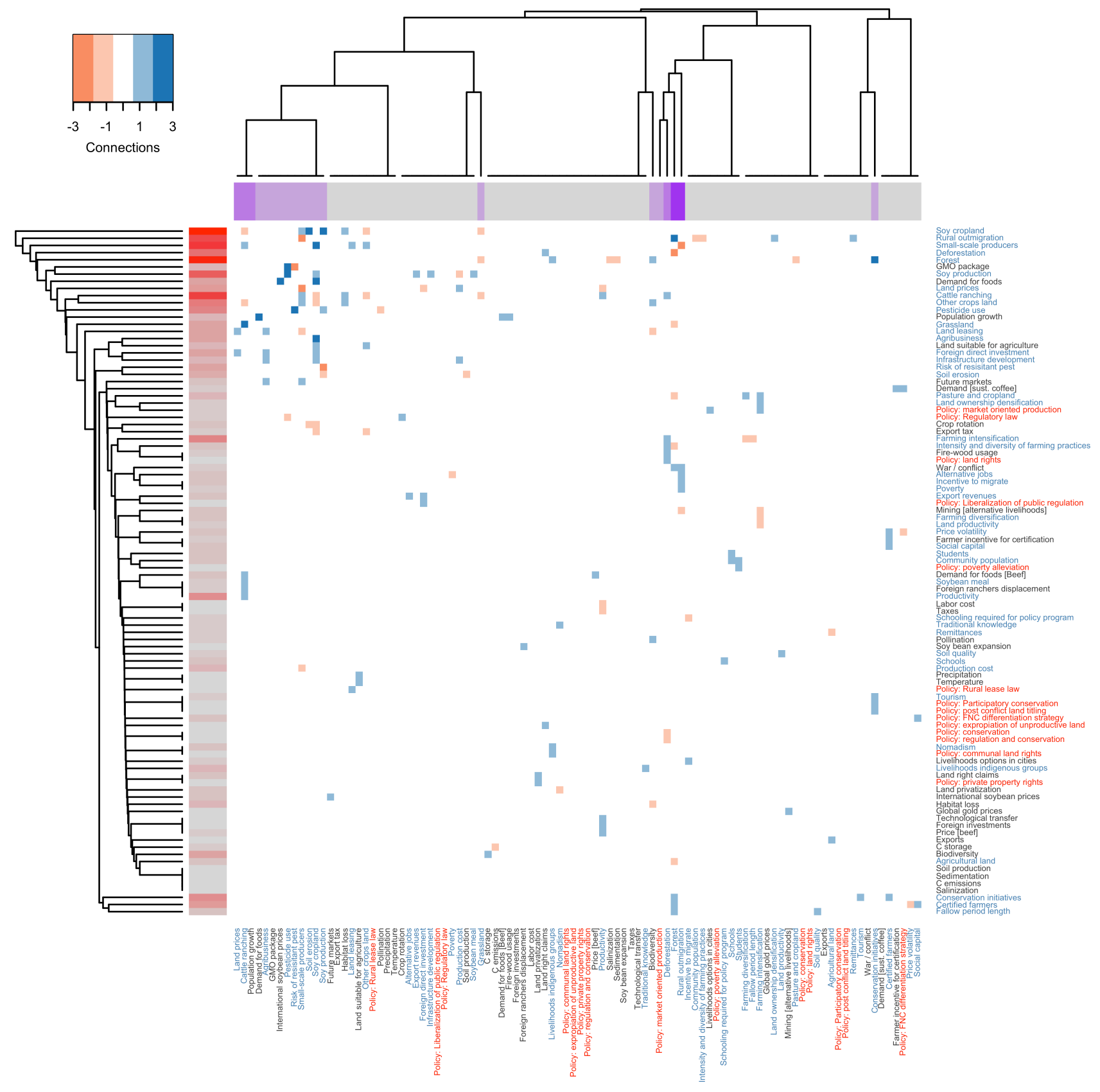


Santander, and Cabañas cases. In Colombia and El Salvador, this transition was intentional, with civil society efforts to link conservation to local, small-holder economies. In Brazil, however, new income options from social subsidies and off-farm employment encouraged land abandonment. Forest cover change in Brazil was characterized by rural out-migration, whereas in Santander and Cabañas "bottom-up" initiatives for conservation were underlying land transformation.

Another common trend across case studies is land-use change linked to the technification of agriculture, which includes the use of heavy machinery, genetically modified varieties, supplemental fertilizers and pesticides, as well as standards for certification. In South America, the development of genetically modified crops, in particular soybeans, enabled intensification of export-oriented agricultural practices, raising economic returns, and allowing expansion even into less suitable lands (Gasparri and de Waroux 2014, Garrett and Rausch 2016). The effects of the new technologies in agriculture are complex and differentiated but some evidence suggests that having less capital-intensive and labor-sparing technologies make it increasingly hard for smallholders to compete with large-scale intensive agriculture (Flachsbarth et al. 2015). In Aveiro/Ruropolis, agrarian development programs introduced modified crop and cattle varieties, while income increases allowed family farmers to purchase chemical inputs and expand production. Similarly, new financial tools, such as opportunities to sell harvests on the futures market, have facilitated access to capital for producers, furthering the effect of general increases in foreign direct investments in the region (Bárcena and Prado 2015). Ecological feedbacks were also a common denominator across cases that further reinforced landcover change. Erosion and soil degradation were particularly important aspects in Uruguay, Brazil, and Paraguay.

Land-rights issues and out-migration are also common across cases, with a tendency toward land ownership concentration. In Argentina, soybean expansion displaced subsistence farmers and their cropping systems (corn, sunflower) from the Pampas plains. In Uruguay, pastures were transformed into soybean plantations displacing cattle ranchers and mixed systems to Paraguay, further engendering land conflict with large investors, local smallholders, and cultural minorities such as indigenous groups, and making explicit that the case studies also serve to illustrate spillover or leakage effects. Such dynamics are absent from regions in which local topography makes large-scale expansion impractical, such as the coffee case in Colombia. Conflict plays a role in some cases, with war driving forest regeneration in El Salvador and property rights disputes between agribusiness, small-scale farmers, and indigenous communities resulting from ranching expansion in Chaco.

The case studies also make explicit how land systems are telecoupled (Liu et al. 2013, 2015) with spillover and leakage effects arising from different legal frameworks and conditioning how international commodity trade influence land-use decision making across Latin America. Argentinean agro-firms expanded into Uruguay beginning in the early 2000s to diversify risk and to take advantage of export and investment friendly political frameworks and regulations (e.g., no export taxes on soybeans in contrast with Argentina). Soybean expansion in Uruguay then led to a rapid rise of land prices, driving Uruguayan ranchers to sell or lease their arable land to new crop firms and move their own operations to less suitable areas in other countries, such as Paraguay. In fact, Argentinian, Uruguayan, and Brazilian ranchers expanded the agricultural frontier through deforestation in the Chaco. These trends are also visible on the trade profile of these countries (Appendix 1, Fig. A1.8).

\section{Leverage points}

Policies are often portrayed as drivers of land-use and land-cover change (Duit 2014), yet our case study comparisons indicate that policy outcomes are often nonlinear and have unforeseen consequences. Although the CLD highlights the importance of policies as drivers and as points of intervention, the strength and effectiveness of each policy is context dependent. For example, the increase of export taxes on soybeans in Argentina made it more attractive for Argentinean crop firms to expand cultivations in Uruguay. Policies in one region can have spillover effects and displace land use to other regions (Lambin and Meyfroidt 2011) as was the case in Paraguay in which the "zero deforestation" law, designed to protect the Atlantic rainforest, increased pressures on the forests of the Chaco (le Polain de Waroux et al. 2016). The Paraguayan case also evidences how conflicting policies, such as those that alternatively support communal and private land rights, can be used to exacerbate land conflicts. Current legal frameworks governing land tenure tend to support private, formalized, and individual forms of land ownership over small scale, informal, and common ownership typical of smallholders and indigenous groups, thus favoring elite capture by powerful actors while further marginalizing others. In both Paraguay and Brazil, there have been contradictions between environmentalist and developmentalist policies, although asymmetrical state capacities to implement market-oriented projects over conservation programs means that corporate expansion is often favored over community-based, participatory actions (Abers et al. 2017). This highlights how national policies, the geopolitics of development, and the influential lobbying of powerful actors raise important questions about social equity that are embedded within land-change processes.

Policy clashes are less straightforward in the Uruguayan, Salvadoran, and Colombian cases. Uruguay has favored deregulation and liberalization reforms including absence of export taxes to attract foreign direct investments, but now promotes mandatory crop rotation and regulates the use of pesticides and fertilizers. In El Salvador, resettlement policies for excombatants and refugees were originally in conflict with the goals those same combattants to maintain forest recovery. Bottom-up conservation efforts by these same groups in the postwar years resulted in eventual legal protection of the recovered forests (de Bremond 2007, 2008, 2013). In the Colombian case, without a national level policy to differentiate in the international coffee market, the certification scheme would not have been functional at the municipality level. Understanding how international telecouplings, linking consumers in high income countries with producers in middle and low income countries, is crucial for informing policies that foster transitions toward more sustainable social-ecological interactions. Some policy interventions intended to counteract the negative impacts of agricultural expansion, for example, the soy moratorium in Brazil and the Argentine zonation Law, might be partially responsible for the post-2007 slowdown in agricultural expansion, 
or merely a reaction to the global economic recession and hence, just a temporary feature (Graesser et al. 2015).

\section{DISCUSSION}

We employ archetypes as analytical abstractions intended to capture the processes that underlie recurrent patterns or trends observed in land systems. Our cases describe land-use and landcover transitions as potential regime shifts (we do not know if they will be stable in the future) either from forest to agriculture, from small-scale cropping to industrialized agriculture, or from cropland to secondary regrowth. The most important links, according to the structural equivalence analysis, were between forest cover, deforestation, and rural migration, indicating that they are key processes across case studies. Land change was also characterized by international trade, food demand, commodity prices, and technological improvements.

Although recent land-use change in Latin America is mainly driven by distal demand (increased demand on soybeans, timber, and meat; Meyfroidt et al. 2014), public policies are also found to be important. However, their effects are not straightforward. When examining policies as leverage points, the presence of policies does not guarantee achievement of intended effects. Even so, policies remain a primary leverage point across cases, making it critical to account for potential synergies and conflicts between policies or institutions in considering potential effectiveness. Our results show how national policy schemes can create spillover effects and impact land-use change in other areas of Latin America. Accordingly, policy design to achieve sustainable development goals in the region will need to take into account telecouplings between different social-ecological systems and move beyond national policy regulation into regional policy coordination, such as through current regional governance structures, e.g., Consejo Agropecuario del Sur (CAS, Agriculture Council of the South).

\section{Toward a database of land-use archetypes that integrates social and ecological dynamics}

Databases are useful for cross comparing and synthesizing knowledge; they can support theory building and identify points of intervention (Biggs et al. 2018). Online collaborative platforms that seek to understand local change at the global scale already exist. Earth Systems Science's GLOBE (http://globe.umbc.edu/) offers a number of global datasets of biophysical and socioeconomic aggregates commonly used in land-use classifications (Ellis 2012). Although process-based modeling for land change does exist (e.g., Magliocca et al. 2013, 2014, 2015), the step toward theory building demands much more attention. Data driven classifications of land use abound (Ellis and Ramankutty 2008, Letourneau et al. 2012, van Asselen and Verburg 2012, Václavík et al. 2013, Levers et al. 2018), but processbased models for theoretical development are lacking despite a relatively rich case study-based literature on land-use and landcover change (Meyfroidt 2016). We contribute to this body of work by qualitatively developing a series of causal hypotheses in the form of CLDs, and by leveraging comparison, which helps us distinguish more general aspects from context dependence between case studies. Although Václavík et al. (2013) used a datadriven approach to generate 12 global land-use archetypes, our approach complements theirs by including social dynamics, such as the role of policies, the driving force of trade, land conflicts with minorities, or patterns of land ownership, which are not possible to grasp from remote sensing data. This can improve understanding of the linkages between patterns and processes of land-system change.

Our work highlights the potential importance of combining geospatial data with variables that are not currently included in such global efforts. Such variables include relational data and flows such as national or international trade, rural migration, or remittances; as well as institutional fine-grain data such as land ownership or rules and policies. Thus, our work complements previous efforts for studying regime shifts in social-ecological systems (Biggs et al. 2018) by operationalizing existing frameworks to incorporate socially driven dynamics. Although our analysis is done on a case-by-case basis, we argue for the development of a database (building on the experience of the regime shifts database) to identify a minimal set of causal mechanisms that account for observed trends. Our work contributes to assessments of resilience by identifying key feedback processes, drivers, and leverage points in a comparative fashion (Meyfroidt et al. 2018). Our method explores a middle range assessment that goes beyond individual cases, retains some of their context, but looks for generalization, e.g., common regime shifts in land-use dynamics. Case study comparisons are useful because they help to tease out similarities across systems and can illustrate observable properties related to resilience (Carpenter et al. 2005).

Critical to this immediate research challenge is increasing public data accessibility. The causal networks presented highlight potential destabilizing or stabilizing processes in the system, which are a good place to look for resilience surrogates (Bennett et al. 2005), but they lack temporal information about unfolding dynamics. Hypotheses about the presence, strength and relevant scale of causal mechanisms should be tested with empirical data. Our exercise sheds light on some of the observables or surrogates that could be sampled (land tenure, rural migration, remittances, land conflict records, yields, national and international trade, commodity prices, disease rates) to better characterize regimes on a finer-grained scale than the current global or regional classifications. However, public data are scattered when available and making them open access is necessary to advance science. Although modeling has traditionally been an approach to explore hypothetical scenarios, further testing of mechanisms requires extensive empirical support.

\section{CONCLUSION}

Unprecedented land-use and land-cover change has occurred in Latin America over the last two decades. Whereas there has been a growing consensus concerning the necessity of planning for resilient landscapes, not least to fulfill the committed goals of the UN Agenda 2030, attempts to operationalize and upscale resilience analysis have so far been limited, or imposed high data demands. We explored a candidate methodology for filling this gap, revisiting the approach of system archetypes to identify resilience surrogates, with a focus on land-use regime shifts in social-ecological systems in Latin America. By creating a data template to synthesize insights on key processes and patterns of land-use change, and by collecting literature based and expert knowledge on seven case studies across Latin America, we constructed causal loop diagrams and studied their structural 
similarity in the form of causal networks. This allowed us to facilitate comparison and to identify similarities across systems, such as common drivers and trends, without losing sight of the context specificities. Searching for what is archetypical, we found deforestation, international trade, food demand, commodity prices, and technological change to stand out across cases. Although more cases are needed to characterize land-use change in Latin America, our preliminary results show that policy outcomes are often nonlinear with unforeseen consequences, including leakage effects between cases. Our approach complements existing data-driven approaches to generate archetypes by including social dynamics that are hard to grasp from remote sensing data. Finally, we make a call to the broader scientific community for the development of a database to identify minimal sets of causal mechanisms, i.e., archetypes, which account for observed trends, moving beyond the case-by-case basis analysis. We have shown how comparative analysis can be useful to distinguish generic patterns from context dependent attributes in social-ecological research.

Responses to this article can be read online at: http://www.ecologyandsociety.org/issues/responses. php/10349

\section{Acknowledgments:}

This work would have not been possible without the creative ideas and initial systematic thinking and coordination of Daniel Ospina. We also appreciate the feedback on early stages of this idea by Francisco Alpizar, Bryan Finnegan, Rafael Bernardi, Nestor Mazzeo, Marten Scheffer, and Matias Piaggio, as well as the general support of the South American Institute for Resilience and Sustainability Studies (SARAS).

\section{LITERATURE CITED}

Abers, R. N., M. S. de Oliveira, and A. K. Pereira. 2017. Inclusive development and the asymmetric state: big projects and local communities in the Brazilian Amazon. Journal of Development Studies 53:857-872. http://dx.doi.org/10.1080/00220388.2016.1208177

Arbeletche, P., M. Coppola, and C. Paladino. 2012. Análisis del agro-negocio como forma de gestión empresarial en América del Sur: el caso uruguayo. Agrociencia Uruguay 16:110-119.

Baraibar, M. 2014. Green deserts or new opportunities?: competing and complementary views on the soybean expansion in Uruguay, 2002-2013. Dissertation. Stockholm University, Stockholm, Sweden. [online] URL: http://su.diva-portal.org/smash/get/ diva2:737424/FULLTEXT01.pdf

Bárcena, A., and A. Prado. 2015. Neoestructuralismo y corrientes heterodoxas en América Latina y el Caribe a inicios del siglo XXI. Comisión Económica para América Latina y el Caribe (CEPAL), Santiago, Chile. [online] URL: https://repositorio.cepal.org/ bitstream/handle/11362/37648/S1500293 es.pdf?sequence $=4$

Bennett, E. M., G. S. Cumming, and G. D. Peterson. 2005. A systems model approach to determining resilience surrogates for case studies. Ecosystems 8:945-957. http://dx.doi.org/10.1007/ $\underline{\mathrm{s} 10021-005-0141-3}$
Biggs, R., G. D. Peterson, and J. C. Rocha. 2018. The Regime Shifts database: a framework for analyzing regime shifts in socialecological systems. Ecology and Society 23(3):9. https://doi. org/10.5751/ES-10264-230309

Biggs, R., M. Schlüter, D. Biggs, E. L. Bohensky, S. BurnSilver, G. Cundill, V. Dakos, T. M. Daw, L. S. Evans, K. Kotschy, A. M. Leitch, C. Meek, A. Quinlan, C. Raudsepp-Hearne, M. D. Robards, M. L. Schoon, L. Schultz, and P. C. West. 2012. Toward principles for enhancing the resilience of ecosystem services. Annual Review of Environment and Resources 37:421-448. http:// dx.doi.org/10.1146/annurev-environ-051211-123836

Carpenter, S. R., F. Westley, and M. G. Turner. 2005. Surrogates for resilience of social-ecological systems. Ecosystems 8:941-944. http://dx.doi.org/10.1007/s10021-005-0170-y

Dakos, V., S. R. Carpenter, E. H. van Nes, and M. Scheffer. 2015. Resilience indicators: prospects and limitations for early warnings of regime shifts. Philosophical Transactions of the Royal Society of London. Series B, Biological Sciences 370:2013.0263. http://dx. doi.org/10.1098/rstb.2013.0263

de Almeida, C. A., A. C. Coutinnho, J. C. D. M. Esquerdo, M. Adami, A. Venturieri, C. G. Diniz, N. Dessay, L. Durieux, and A. R. Gomes. 2016. High spatial resolution land use and land cover mapping of the Brazilian Legal Amazon in 2008 using Landsat-5/TM and MODIS data. Acta Amazonica 46:291-302. http://dx.doi.org/10.1590/1809-4392201505504

de Bremond, A. C. 2006. Regenerating conflicted landscapes: land, environmental governance, and resettlement in post-war $\mathrm{El}$ Salvador. Dissertation. University of California Santa Cruz, Santa Cruz, California, USA.

de Bremond, A. 2007. The politics of peace and resettlement through El Salvador's land transfer programme: caught between the state and the market. Third World Quarterly 28:1537-1556. http://dx.doi.org/10.1080/01436590701637391

de Bremond, A. 2008. The politics of peace and resettlement through El Salvador's land transfer programme: caught between the state and the market. In S. M. Borras, Jr., C. Kay, and E. Lahiff, editors. Market-led agrarian reform: critical perspectives on neoliberal land policies and the rural poor. Routledge, New York, New York, USA.

de Bremond, A. 2013. Regenerating conflicted landscapes in postwar El Salvador: livelihoods, land policy, and land use change in the Cinquera Forest. Journal of Political Ecology 20:116-136. http://dx.doi.org/10.2458/v20i1.21761

de Castro, F., B. Hogenboom, and M. Baud. 2016. Environmental governance in Latin America. Palgrave-Macmillan, New York, New York, USA. http://dx.doi.org/10.1007/978-1-137-50572-9

Duit, A. 2014. State and environment: the comparative study of environmental governance. MIT Press, Cambridge, Massachusetts, USA. http://dx.doi.org/10.7551/mitpress/9780262027120.001.0001

Eisenack, K. 2014. Archetypes of adaptation to climate change. Pages 107-122 in M. Glaser, G. Krause, B. M. W. Ratter, and M. Welp, editors. Human-nature interactions in the Anthropocene: potentials of social-ecological systems analysis. Taylor and Francis, Abingdon, UK. 
Ellis, E. C., and N. Ramankutty. 2008. Putting people in the map: anthropogenic biomes of the world. Frontiers in Ecology and the Environment 6:439-447. http://dx.doi.org/10.1890/070062

Ellis, E. C. 2012. The GLOBE project: accelerating global synthesis of local studies in land change science. Newsletter of the Global Land Project 8:5-6. [online] URL: https://glp.earth/sites/ default/files/publications/glpnewsletter 8 mar 2012 0.pdf

Flachsbarth, I., B. Willaarts, H. Xie, G. Pitois, N. D. Mueller, C. Ringler, and A. Garrido. 2015. The role of Latin America's land and water resources for global food security: environmental tradeoffs of future food production pathways. PLOS ONE 10: e0116733. http://dx.doi.org/10.1371/journal.pone.0116733

Folke, C. 2016. Resilience (Republished). Ecology and Society 21 (4):44. http://dx.doi.org/10.5751/ES-09088-210444

Folke, C., S. Carpenter, B. Walker, M. Scheffer, T. Elmqvist, L. Gunderson, and C. S. Holling. 2004. Regime shifts, resilience, and biodiversity in ecosystem management. Annual Review of Ecology, Evolution, and Systematics 35:557-581. http://dx.doi. org/10.1146/annurev.ecolsys.35.021103.105711

Garrett, R. D., and L. L. Rausch. 2016. Green for gold: social and ecological tradeoffs influencing the sustainability of the Brazilian soy industry. Journal of Peasant Studies 43:461-493. http://dx.doi.org/10.1080/03066150.2015.1010077

Gasparri, N. I., and Y. L. P. de Waroux. 2015. The coupling of South American soybean and cattle production frontiers: new challenges for conservation policy and land change science. Conservation Letters 8:290-298. http://dx.doi.org/10.1111/ conl.12121

Gelabert, C., F. Rositano, and O. González. 2017. Sustainable use of caiman in Argentina: an analysis from the perspective of the stakeholders involved. Biological Conservation 212:357-365. http://dx.doi.org/10.1016/j.biocon.2017.06.012

Gibbs, H. K., A. S. Ruesch, F. Achard, M. K. Clayton, P. Holmgren, N. Ramankutty, and J. A. Foley. 2010. Tropical forests were the primary sources of new agricultural land in the 1980s and 1990s. Proceedings Of The National Academy Of Sciences 107:16732-16737. http://dx.doi.org/10.1073/pnas.0910275107

Graesser, J., T. M. Aide, H. R. Grau, and N. Ramankutty. 2015. Cropland/pastureland dynamics and the slowdown of deforestation in Latin America. Environmental Research Letters 10:034017. http://dx.doi.org/10.1088/1748-9326/10/3/034017

Handcock, M. S., D. R. Hunter, C. T. Butts, S. M. Goodreau, and M. Morris. 2008. Statnet: software tools for the representation, visualization, analysis and simulation of network data. Journal of Statistical Software 24:1548. http://dx.doi.org/10.18637/jss. $\underline{\mathrm{v} 024.101}$

Jobbágy, E. G., H. R. Grau, J. M. Paruelo, and E. F. Viglizzo. 2015. Farming the Chaco: tales from both sides of the fence. Journal Of Arid Environments 123:1-2. http://dx.doi.org/10.1016/ j.jaridenv.2015.07.011

Kuemmerle, T., M. Altrichter, G. Baldi, M. Cabido, M. Camino, E. Cuellar, R. L. Cuellar, J. Decarre, S. Díaz, I. Gasparri, G. Gavier-Pizarro, R. Ginzburg, A. J. Giordano, H. R. Grau, E. Jobbágy, G. Leynaud, L. Macchi, M. Mastrangelo, S. D.
Matteucci, A. Noss, J. Paruelo, M. Piquer-Rodríguez, A. RomeroMuñoz, A. Semper-Pascual, J. Thompson, S. Torrella, R. Torres, J. N. Volante, A. Yanosky, and M. Zak. 2017. Forest conservation: remember Gran Chaco. Science 355:465. http://dx.doi. org/10.1126/science.aal3020

Lambin, E. F., H. K. Gibbs, L. Ferreira, R. Grau, P. Mayaux, P. Meyfroidt, D. C. Morton, T. K. Rudel, I. Gasparri, and J. Munger. 2013. Estimating the world's potentially available cropland using a bottom-up approach. Global Environmental Change 23:892-901. http://dx.doi.org/10.1016/j.gloenvcha.2013.05.005

Lambin, E. F., and P. Meyfroidt. 2011. Global land use change, economic globalization, and the looming land scarcity. Proceedings of the National Academy of Sciences 108:3465-3472. http://dx.doi.org/10.1073/pnas.1100480108

le Polain de Waroux, Y., R. D. Garrett, R. Heilmayr, and E. F. Lambin. 2016. Land-use policies and corporate investments in agriculture in the Gran Chaco and Chiquitano. Proceedings of the National Academy of Sciences 113:4021-4026. http://dx.doi. org/10.1073/pnas.1602646113

Letourneau, A., P. H. Verburg, and E. Stehfest. 2012. A land-use systems approach to represent land-use dynamics at continental and global scales. Environmental Modelling and Software 33:61-79. http://dx.doi.org/10.1016/j.envsoft.2012.01.007

Levers, C., D. Müller, K. Erb, H. Haberl, M. R. Jepsen, M. J. Metzger, P. Meyfroidt, T. Plieninger, C. Plutzar, J. Stürck, P. H. Verburg, P. J. Verkerk, and T. Kuemmerle. 2018. Archetypical patterns and trajectories of land systems in Europe. Regional Environmental Change 18:715-732. http://dx.doi.org/10.1007/ s10113-015-0907-X

Liu, J., V. Hull, M. Batistella, R. DeFries, T. Dietz, F. Fu, T. W. Hertel, R. C. Izaurralde, E. F. Lambin, S. Li, L. A. Martinelli, W. J. McConnell, E. F. Moran, R. Naylor, Z. Ouyang, K. R. Polenske, A. Reenberg, G. de Miranda Rocha, C. S. Simmons, P. H. Verburg, P. M. Vitousek, F. Zhang, and C. Zhu. 2013. Framing sustainability in a telecoupled world. Ecology and Society 18 (2):26. http://dx.doi.org/10.5751/ES-05873-180226

Liu, J., H. Mooney, V. Hull, S. J. Davis, J. Gaskell, T. Hertel, J. Lubchenco, K. C. Seto, P. Gleick, C. Kremen, and S. Li. 2015. Systems integration for global sustainability. Science 347:1258832. http://dx.doi.org/10.1126/science.1258832

Liu, Y.-Y., and A.-L. Barabasi. 2016. Control principles of complex networks. Reviews of Modern Physics 88:035006. https:// doi.org/10.1103/RevModPhys.88.035006

MacDonald, G. K., K. A. Brauman, S. Sun, K. M. Carlson, E. S. Cassidy, J. S. Gerber, and P. C. West. 2015. Rethinking agricultural trade relationships in an era of globalization. BioScience 65:275-289. http://dx.doi.org/10.1093/biosci/biu225

Magliocca, N. R., D. G. Brown, and E. C. Ellis. 2013. Exploring agricultural livelihood transitions with an agent-based virtual laboratory: global forces to local decision-making. PLOS ONE 8: e73241. http://dx.doi.org/10.1371/journal.pone.0073241

Magliocca, N. R., D. G. Brown, and E. C. Ellis. 2014. Cross-site comparison of land-use decision-making and its consequences across land systems with a generalized agent-based model. PLoS ONE 9:e86179. http://dx.doi.org/10.1371/journal.pone.0086179 
Magliocca, N. R., E. C. Ellis, G. R. H. Allington, A. de Bremond, J. Dell'Angelo, O. Mertz, P. Messerli, P. Meyfroidt, R. Seppelt, and P. H. Verburg. 2018. Closing global knowledge gaps: producing generalized knowledge from case studies of socialecological systems. Global Environmental Change 50:1-14. http:// dx.doi.org/10.1016/j.gloenvcha.2018.03.003

Magliocca, N. R., T. K. Rudel, P. H. Verburg, W. J. McConnell, O. Mertz, K. Gerstner, A. Heinimann, and E. C. Ellis. 2015. Synthesis in land change science: methodological patterns, challenges, and guidelines. Regional Environmental Change 15:211-226.

Meadows, D., and D. Wright. 2008. Thinking in systems: a primer. Chelsea Green, White River Junction, Vermont, USA.

Meyfroidt, P. 2016. Approaches and terminology for causal analysis in land systems science. Journal of Land Use Science 11:501-522. http://dx.doi.org/10.1080/1747423X.2015.1117530

Meyfroidt, P., K. M. Carlson, M. E. Fagan, V. H. Gutiérrez-Vélez, M. N. Macedo, L. M. Curran, R. S. DeFries, G. A. Dyer, H. K. Gibbs, E. F. Lambin, D. C. Morton, and V. Robiglio. 2014. Multiple pathways of commodity crop expansion in tropical forest landscapes. Environmental Research Letters 9:074012. http://dx.doi.org/10.1088/1748-9326/9/7/074012

Meyfroidt, P., R. R. Chowdhury, A. de Bremond, E. C. Ellis, K.H.Erb, T. Filatova, R. D. Garrett, J. M.Grove, A. Heinimanne, T. Kuemmerle, C. A. Kull, E. F.Lambina, Y. Landon, Y. le Polain de Waroux, P. Messerli, D. Müller, J. Ø. Nielsen, G. D. Petersonm V. Rodriguez García, M. Schlüter, B. L. Turner, II, and P. H. Verburg. 2018. Middle-range theories of land system change. Global Environmental Change 53:52-67. https://doi.org/10.1016/j. gloenvcha.2018.08.006

Meyfroidt, P., F. Schierhorn, A. V. Prishchepov, D. Müller, and T. Kuemmerle. 2016. Drivers, constraints and trade-offs associated with recultivating abandoned cropland in Russia, Ukraine and Kazakhstan. Global Environmental Change 37:1-15. http://dx.doi.org/10.1016/j.gloenvcha.2016.01.003

Müller, D., Z. Sun, T. Vongvisouk, D. Pflugmacher, J. Xu, and O. Mertz. 2014. Regime shifts limit the predictability of land-system change. Global Environmental Change 28:75-83. http://dx.doi. org/10.1016/j.gloenvcha.2014.06.003

Myers, S. S., and J. A. Patz. 2009. Emerging threats to human health from global environmental change. Annual Review of Environment and Resources 34:223-252. http://dx.doi.org/10.1146/ annurev.environ.033108.102650

Newman, M. E. J. 2009. Networks: an introduction. Oxford University Press, Oxford, UK.

Oberlack, C., L. Tejada, P. Messerli, S. Rist, and M. Giger. 2016. Sustainable livelihoods in the global land rush? Archetypes of livelihood vulnerability and sustainability potentials. Global Environmental Change 41:153-171. http://dx.doi.org/10.1016/j. gloenvcha.2016.10.001

Oestreicher, J. S., N. Farella, S. Paquet, R. Davidson, M. Lucotte, F. Mertens, and J. Saint-Charles. 2014. Livelihood activities and land-use at a riparian frontier of the Brazilian Amazon: quantitative characterization and qualitative insights into the influence of knowledge, values, and beliefs. Human Ecology 42:521-540. http://dx.doi.org/10.1007/s10745-014-9667-3

Oestreicher, J. S., L. Fatorelli, F. Mertens, M. Lucotte, A. Béliveau, S. Tremblay, J. Saint-Charles, and C. Romaña. 2018. Rural livelihood trajectories in the central Brazilian Amazon: growing inequalities, changing practices, and emerging rural-urban relationships over nearly a decade. World Development Perspectives 10-12:34-43. https://doi.org/10.1016/j.wdp.2018.09.003

Ostrom, E. 2007. A diagnostic approach for going beyond panaceas. Proceedings of the National Academy of Sciences 104:15181-15187. http://dx.doi.org/10.1073/pnas.0702288104

Ostrom, E. 2009. A general framework for analyzing sustainability of social-ecological systems. Science 325:419-422. http://dx.doi.org/10.1126/science.1172133

Parry, L., B. Day, S. Amaral, and C. A. Peres. 2010. Drivers of rural exodus from Amazonian headwaters. Population and Environment 32:137-176. http://dx.doi.org/10.1007/s11111-010-0127-8

R Core Team. 2017. R: a language and environment for statistical computing. R Foundation for Statistical Computing, Vienna, Austria. [online] URL: http://www.R-project.org/

Ramankutty, N., and O. T. Coomes. 2016. Land-use regime shifts: an analytical framework and agenda for future land-use research. Ecology and Society 21(2):1. http://dx.doi.org/10.5751/ES-08370-210201

Resilience Alliance. 2011. Assessing resilience in social-ecological systems: workbook for practitioners. Resilience Alliance. [online] URL: https://www.resalliance.org/files/ResilienceAssessmentV2_2. pdf

Rocha, J. C., K. Malmborg, L. Gordon, K. Brauman, and F. DeClerk. 2018. Mapping social ecological systems archetypes. Nonreviewed preprint. bioRxiv 299693. https://doi.org/10.1101/364620

Rositano, F., F. E. Bert, G. Piñeiro, and D. O. Ferraro. 2018. Identifying the factors that determine ecosystem services provision in Pampean agroecosystems (Argentina) using a datamining approach. Environmental Development 25:3-11. http://dx. doi.org/10.1016/j.envdev.2017.11.003

Rositano, F., and D. O. Ferraro. 2014. Ecosystem services provided by agroecosystems: a qualitative and quantitative assessment of this relationship in the Pampa Region, Argentina. Environmental Management 53:606-619. http://dx.doi.org/10.1007/ $\underline{\mathrm{s} 00267-013-0211-9}$

Rozon, C., M. Lucotte, R. Davidson, S. Paquet, J. S. Oestreicher, F. Mertens, C. J. Sousa Passos, and C. Romana. 2015. Spatial and temporal evolution of family-farming land use in the Tapajos region of the Brazilian Amazon. Acta Amazonica 45:203-213. http://dx.doi.org/10.1590/1809-4392201401384

Rudel, T. K. 2011. Is there a forest transition? Deforestation, reforestation, and development. Rural Sociology 63:533-552. https://doi.org/10.1111/j.1549-0831.1998.tb00691.x

Rueda, X., and E. F. Lambin. 2013a. Responding to globalization: impacts of certification on Colombian small-scale coffee growers. Ecology and Society 18(3):21. http://dx.doi.org/10.5751/ ES-05595-180321 
Rueda, X., and E. F. Lambin. 2013b. Linking globalization to local land uses: how eco-consumers and gourmands are changing the Colombian coffee landscapes. World Development 41:286-301. http://dx.doi.org/10.1016/j.worlddev.2012.05.018

Rueda, X., N. E. Thomas, and E. F. Lambin. 2015. Ecocertification and coffee cultivation enhance tree cover and forest connectivity in the Colombian coffee landscapes. Regional Environmental Change 15:25-33. http://dx.doi.org/10.1007/ s10113-014-0607-y

Scheffer, M., S. Carpenter, J. A. Foley, C. Folke, and B. Walker. 2001. Catastrophic shifts in ecosystems. Nature 413:591-596. http://dx.doi.org/10.1038/35098000

Senge, P. M. 1991. The fifth discipline: the art and practice of the learning organization. Performance Improvement 30(5). http://dx. doi.org/10.1002/pfi.4170300510

Sterman, J. D. 2000. Business dynamics: systems thinking and modeling for a complex world. McGraw-Hill Education, New York, New York, USA.

United Nations General Assembly. 2015. Transforming our world: the 2030 Agenda for sustainable development. United Nations, New York, New York, USA. [online] URL: https:// sustainabledevelopment.un.org/content/documents/21252030\% 20Agenda $\% 20$ for $\% 20$ Sustainable $\% 20$ Development $\% 20$ web.pdf

Valencia, D. H., E. M. Riera, and M. B. I. Juncà. 2012. Participatory action research applied to the management of natural areas: the case study of Cinquera in El Salvador. Journal of Latin American Geography 11:45-65. http://dx.doi.org/10.1353/ lag.2012.0009

Vallejos, M., J. N. Volante, M. J. Mosciaro, L. M. Vale, M. L. Bustamante, and J. M. Paruelo. 2015. Transformation dynamics of the natural cover in the Dry Chaco ecoregion: a plot level geodatabase from 1976 to 2012. Journal Of Arid Environments 123:3-11. http://dx.doi.org/10.1016/j.jaridenv.2014.11.009

Václavík, T., S. Lautenbach, T. Kuemmerle, and R. Seppelt. 2013. Mapping global land system archetypes. Global Environmental Change-Human And Policy Dimensions 23:1637-1647. http://dx. doi.org/10.1016/j.gloenvcha.2013.09.004

van Asselen, S., and P. H. Verburg. 2012. A land system representation for global assessments and land-use modeling. Global Change Biology 18:3125-3148. http://dx.doi.org/10.1111/ j.1365-2486.2012.02759.x

Wolstenholme, E. F. 2003. Towards the definition and use of a core set of archetypal structures in system dynamics. System Dynamics Review 19:7-26. http://dx.doi.org/10.1002/sdr.259

Wolstenholme, E. 2004. Using generic system archetypes to support thinking and modelling. System Dynamics Review 20:341-356. http://dx.doi.org/10.1002/sdr.302 


\section{Appendix 1. Supplementary material.}

This document presents the supplementary material for the manuscript "Towards understanding the dynamics of land change in Latin America: Potential utility of a resilience approach for building archetypes of land systems change". The first part presents causal loop diagrams in the form of labelled networks for all case studies. The second part presents a complementary figure about trade exports for Uruguay, Paraguay and Argentina. The third part introduces the reader to the data gathering template and the coding tables $A$ and $B$ that correspond to drivers and trends as synthesized by each contributor. Tables $A$ and $B$ for each case study are presented on the Excel file Appendix 2. Here we only add the complete template for 7 case studies as contributed by their authors.

Causal loop diagrams

Figure A1.1. CLD Forest resurgence in post-war El Salvador

Figure A1.2. CLD cattle ranching expansion and deforestation in paraguayan $\underline{\text { Chaco }}$

Figure A1.3. CLD eco-certification of coffee in Santander, Colombia

Figure A1.4. CLD rural out-migration and farm abandonment in the Pará, Brazil

Figure A1.5. CLD land concentration and ecosystem services in Pampean agroecosystems, Argentina

Figure A1.6. CLD Soybean agribusiness expansion in the Litoral region, Uruguay.

Figure A1.7. CLD expansion of small-scale agriculture and ranching,Pará, Brazil

Trade

Figure A1.8. Export profiles in year 2000 (left) and 2015 (right) for Uruguay $(a, b)$, Paraguay $(c, d)$, Argentina (e,f). Areas are proportional to the export value in dollars per commodity. Source: Observatory of Economic Complexity, data from Comtrade FAO statistics. Interactive versions are available at atlas.media.mit.edu

Data gathering template and coding tables

Forest resurgence in post-war El Salvador

Cattle ranching expansion and deforestation in paraguayan Chaco

Eco-certification of coffee in Santander, Colombia

Rural out-migration and farm abandonment in the Pará, Brazil

Land concentration and ecosystem services in Pampean agroecosystems, Argentina

Soybean agribusiness expansion in the Litoral region, Uruguay

Expansion of small-scale agriculture and ranching,Pará, Brazil 


\section{Causal loop diagrams}

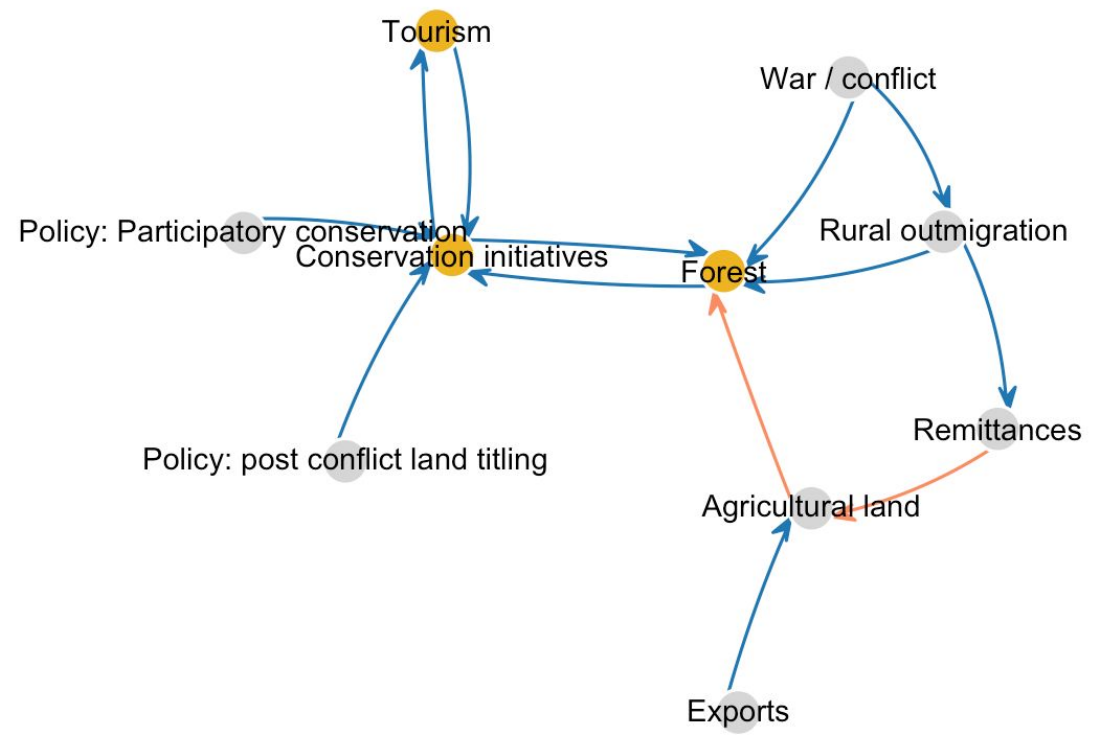

Figure A1.1. CLD Forest resurgence in post-war El Salvador 


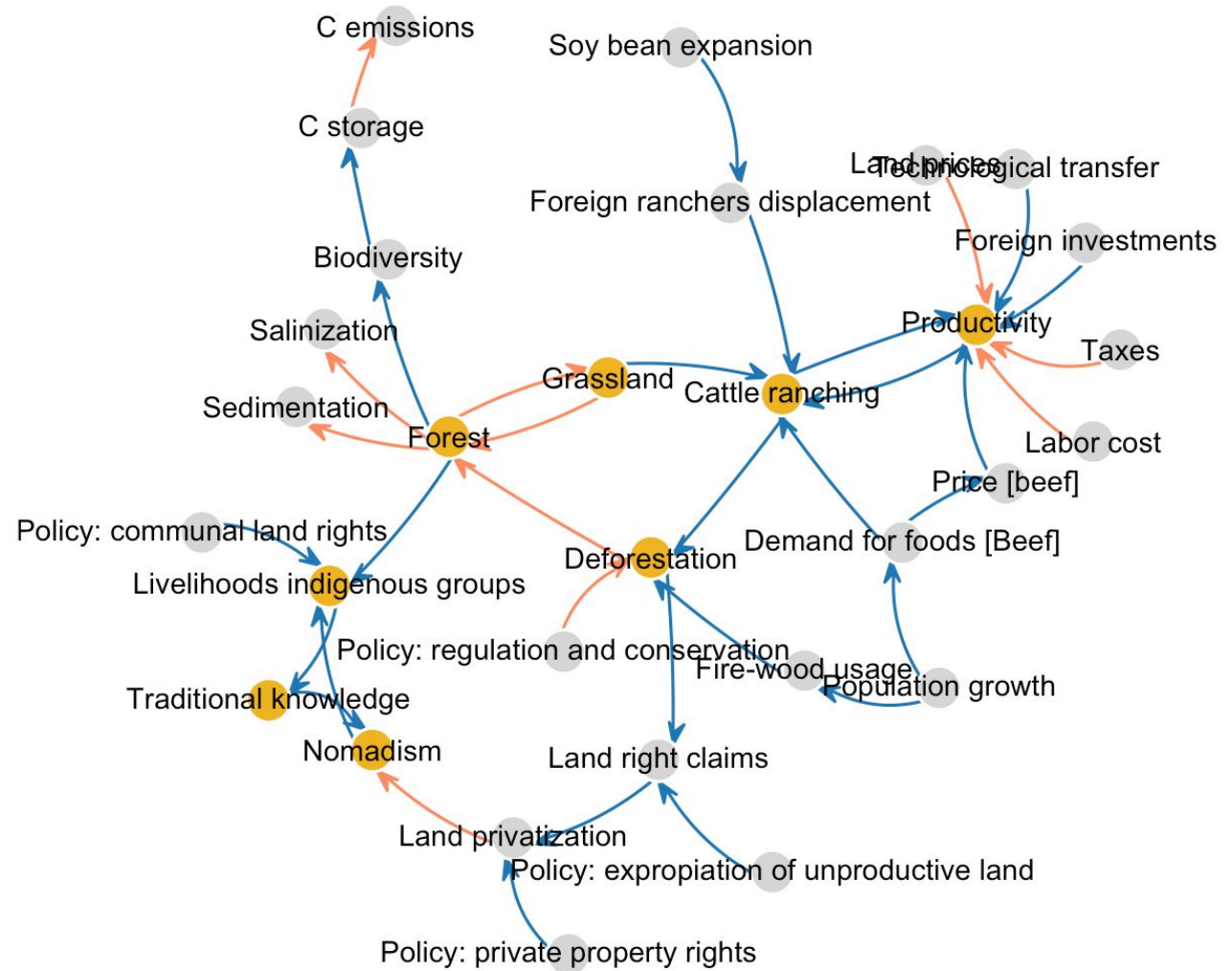

Figure A1.2. CLD cattle ranching expansion and deforestation in Paraguayan Chaco 


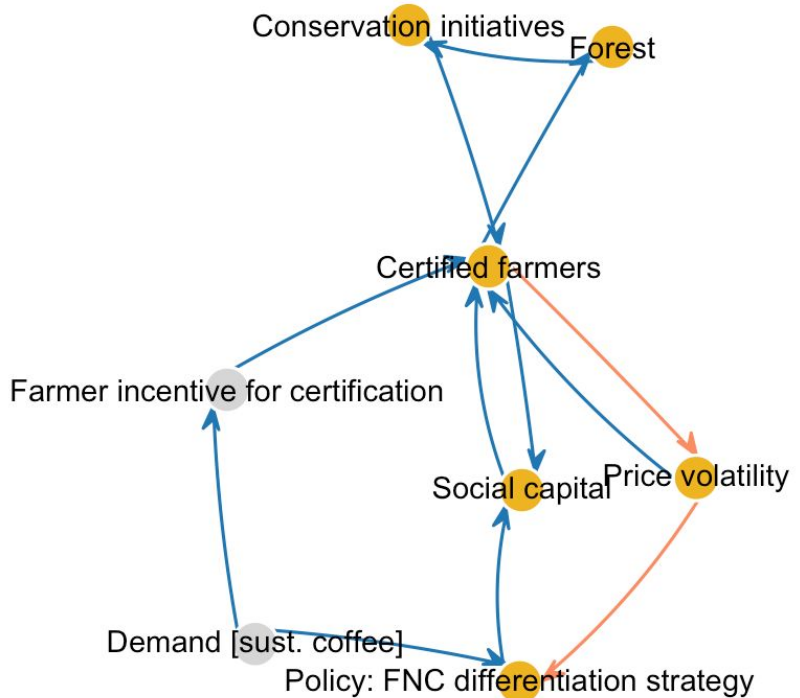

Figure A1.3. CLD eco-certification of coffee in Santander, Colombia 


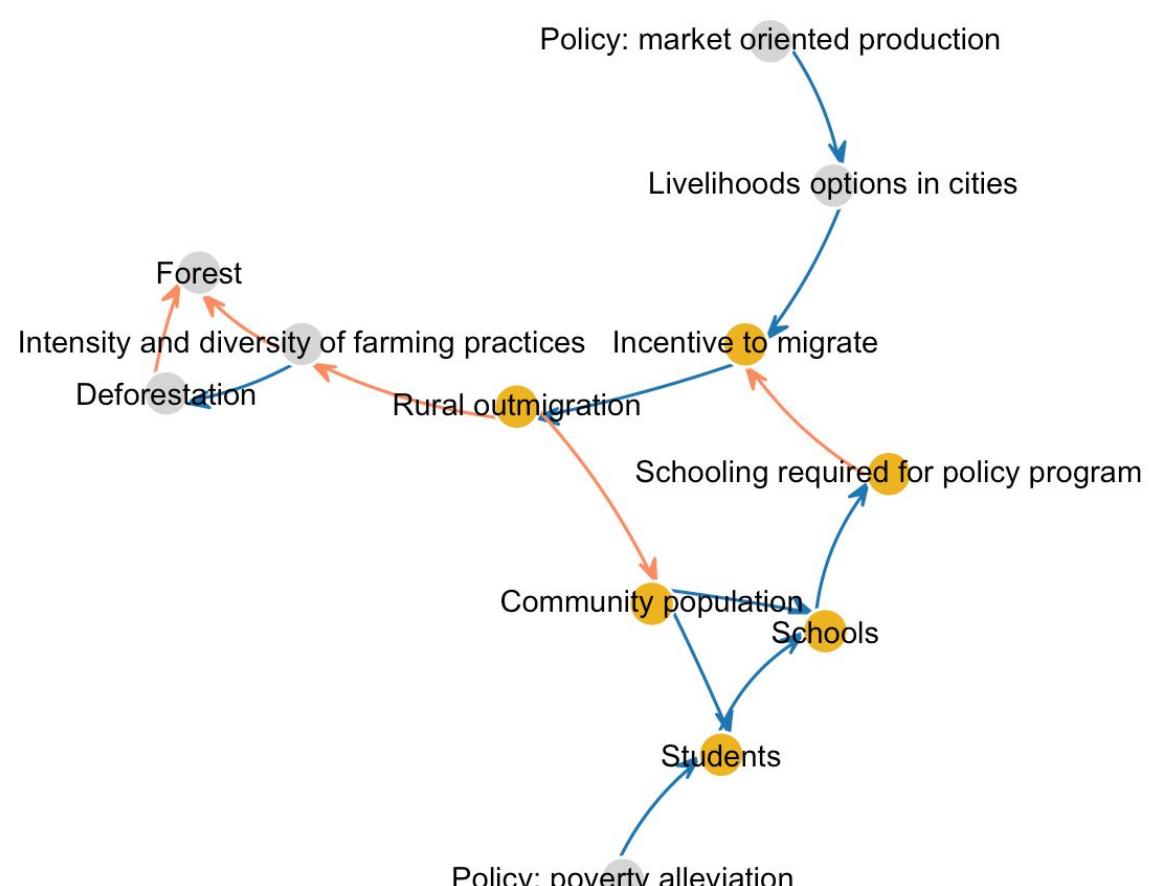

Figure A1.4. CLD rural out-migration and farm abandonment in the Pará, Brazil 


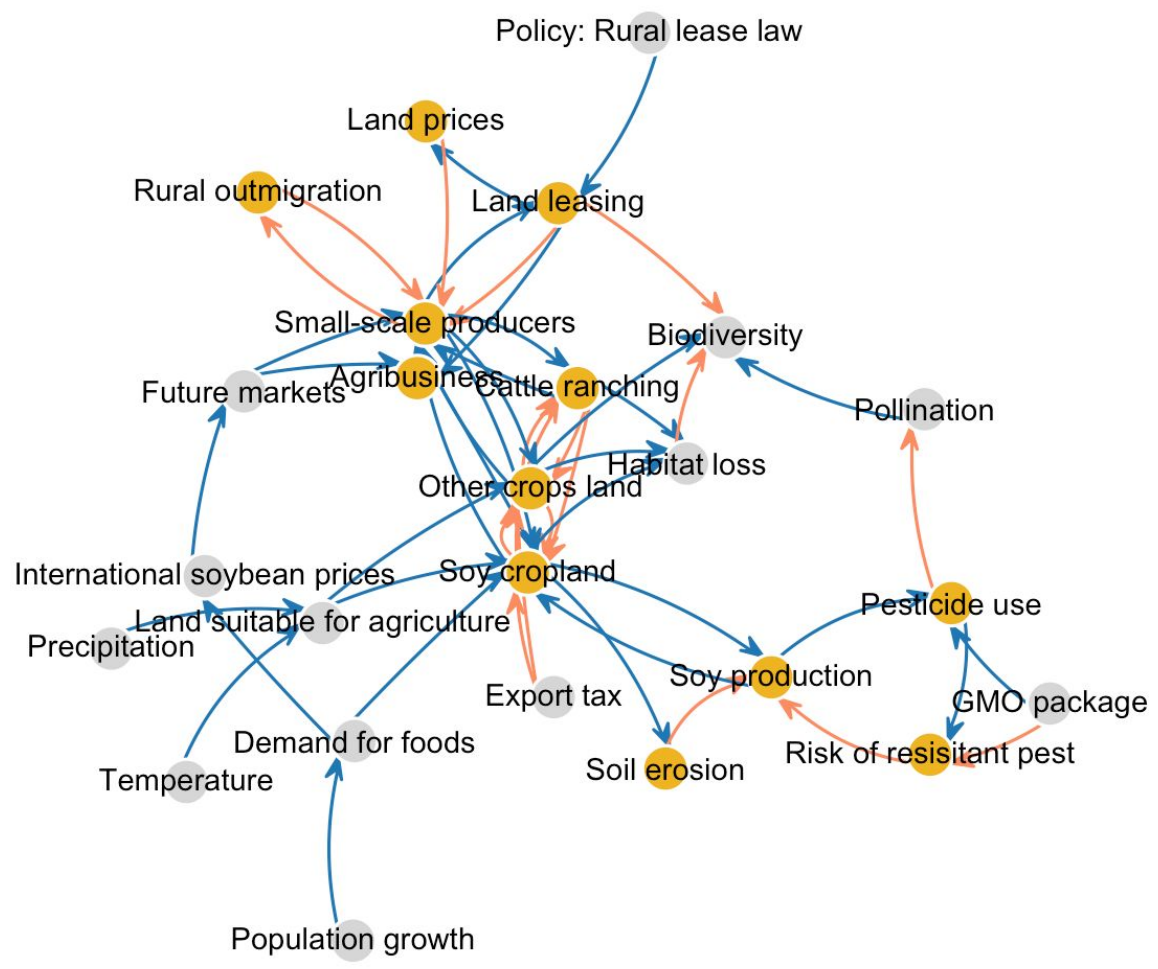

Figure A1.5. CLD land concentration and ecosystem services in Pampean agroecosystems, Argentina 


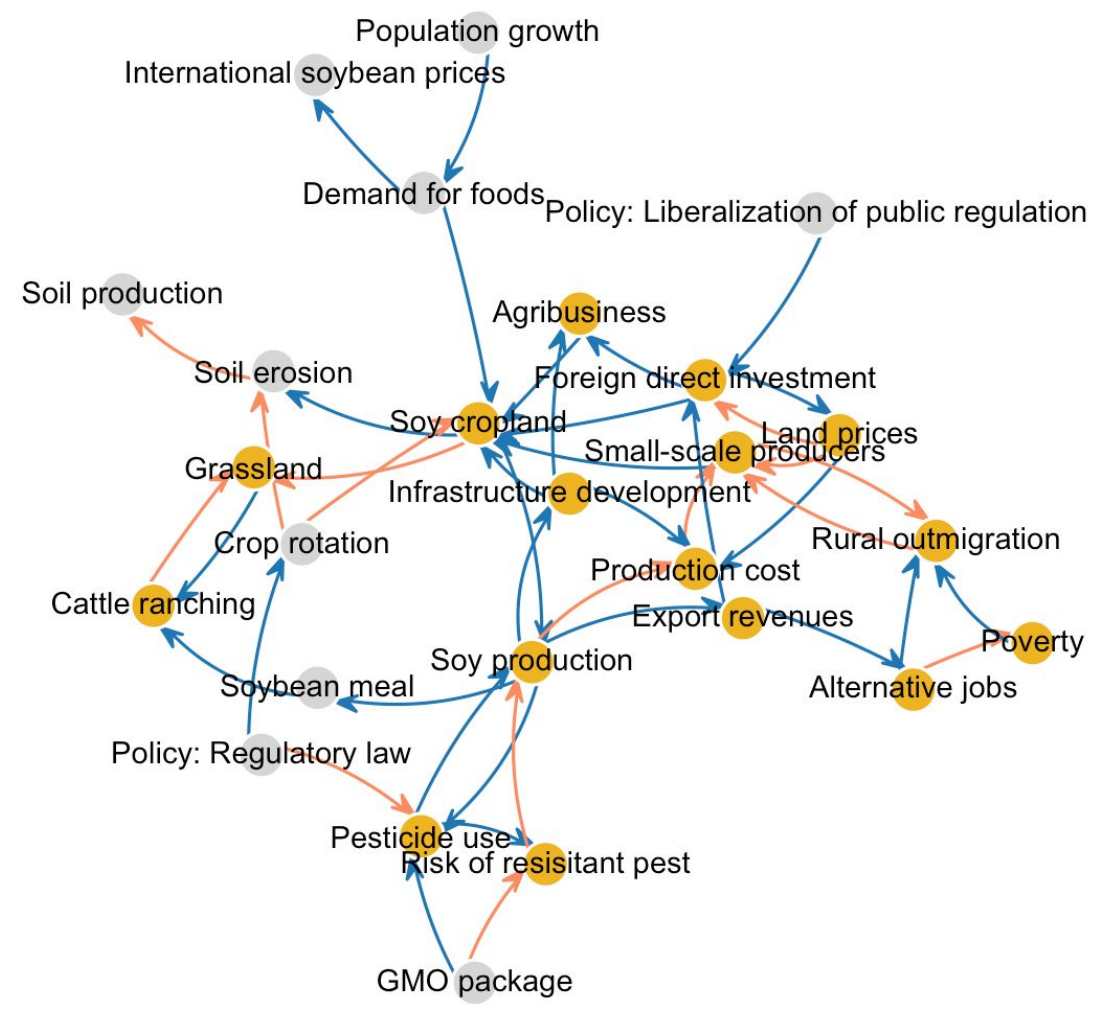

Figure A1.6. CLD Soybean agribusiness expansion in the Litoral region, Uruguay. 


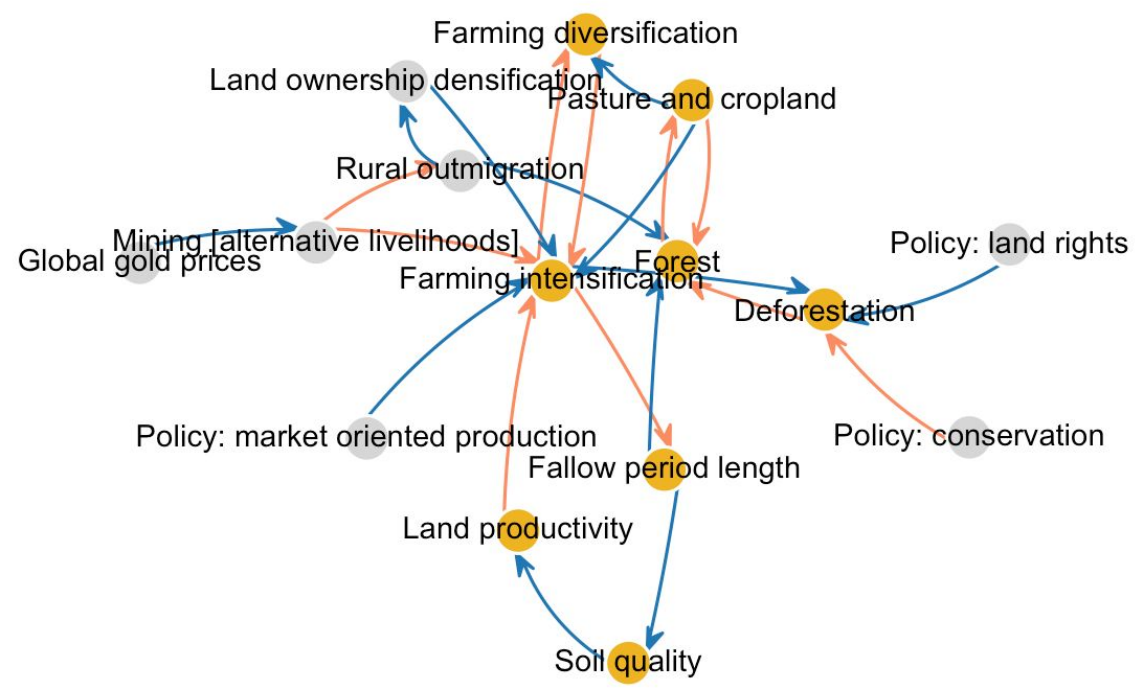

Figure A1.7. CLD expansion of small-scale agriculture and ranching,Pará, Brazil 


\section{Trade}

While the role of Latin America in global agricultural trade declined between 1963 and 2000 (Serrano and Pinilla, 2016), it has grown remarkably since the new Millennium and is now the largest net exporter of food in the world (FAO, 2015). Figure A1.8 corroborates our results by showing the export profiles of Uruguay, Paraguay and Argentina between 2000 and 2015 where our case studies report trade as strong driver. During that period soybean and soy-derived products increased their share of exports in Uruguay, Paraguay and Argentina.

a)

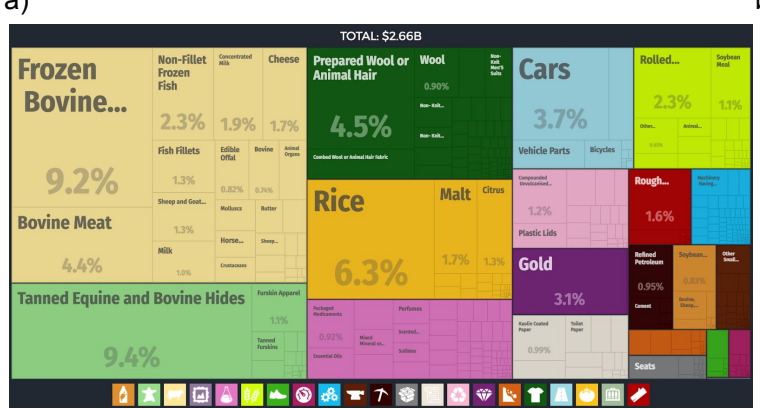

c)

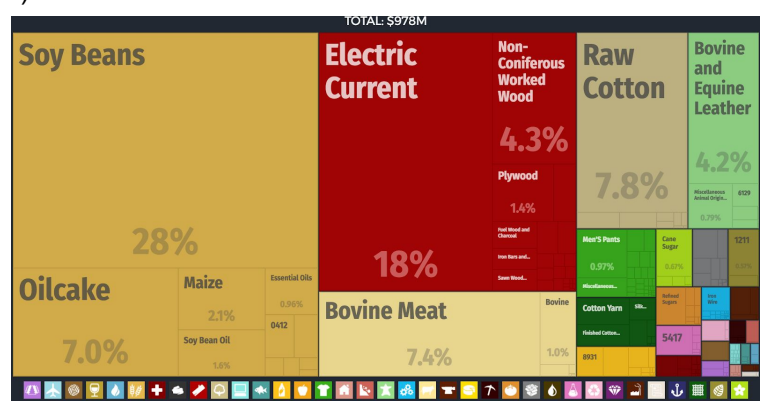

e)
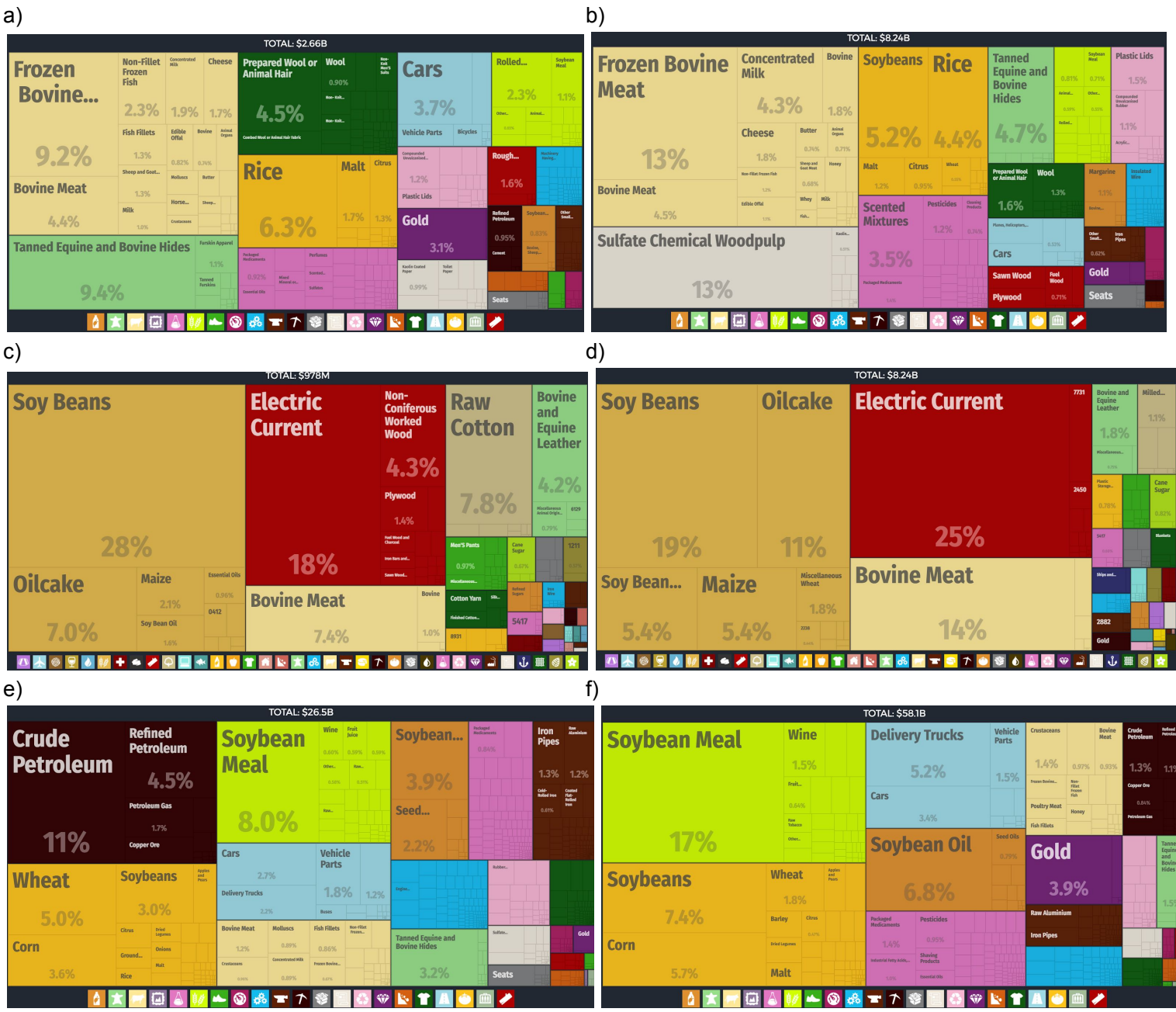

d)
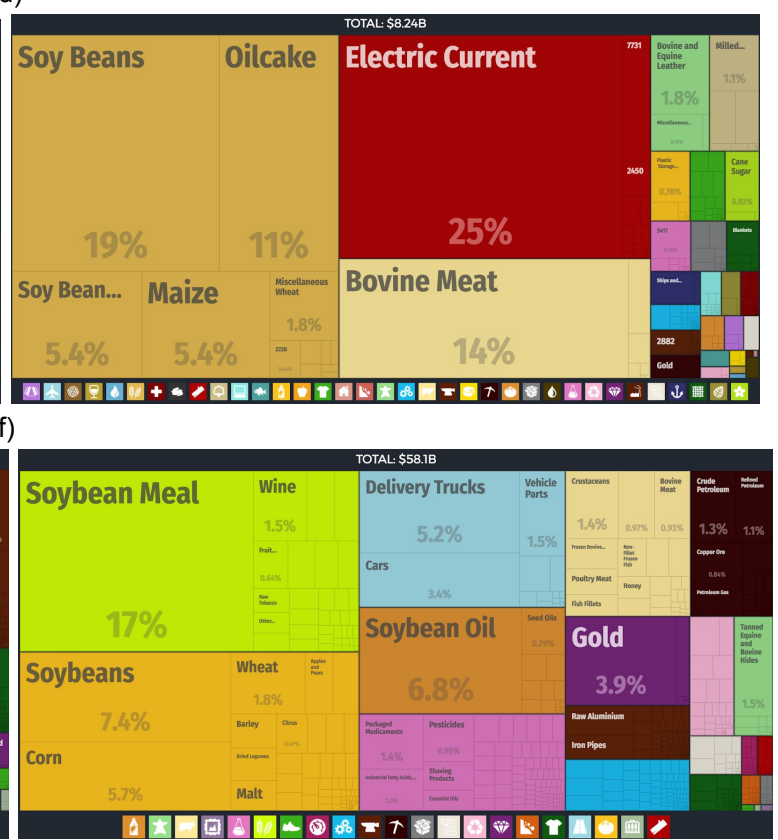

Figure A1.8. Export profiles in year 2000 (left) and 2015 (right) for Uruguay (a,b), Paraguay $(c, d)$, Argentina $(e, f)$. Areas are proportional to the export value in dollars per commodity. Source: Observatory of Economic Complexity, data from Comtrade FAO statistics.

Interactive versions are available at atlas.media.mit.edu 
The proportional share of soybean exports shrank in Paraguay, while meat exports doubled. Argentinean agro-firms expanded into Uruguay beginning in the early 2000 s in order to diversify risks and to take advantage of export and investment friendly political frameworks and regulations (e.g. no export taxes on soybeans in important contrast with Argentina). The soybean expansion in Uruguay led to a rapid rise of land prices. Many traditional ranchers sold or leased out their arable land to the new crop firms, and moved to less suitable land. Paraguay, in turn, received many of the Argentinean, Uruguayan, and Brazilian ranchers, doubling their share of bovine meat exports and expanding their agricultural frontier through deforestation in the Chaco 


\title{
Data gathering template and coding tables
}

\author{
Guidelines for case study data capture \\ (based on expert-knowledge or literature review)
}

Introduction for manuscript co-authors

First version prepared by Daniel Ospina, based on previous work by Juan Carlos Rocha on the Regime Shifts Database. Latter versions improved based on application of the template by Matilda Baraibar (case study: Soybean crop intensification and expansion in Uruguay Litoral)

This template is designed to guide an elicitation of land system archetypes, based on expert-knowledge. We invite the description of case studies of land system dynamics in Latin America. Case studies from a wide range of spatial scales can be included, from the landscape level $\left(\sim 100 \mathrm{~km}^{2}\right)$ to subnational regions $\left(\sim 100.000 \mathrm{~km}^{2}\right)$, covering any period between 1990 until today.

The notion of land system archetype, and how is sits at the centre of an approach to conduct synthesis research, can be confusing at first. We therefore ask the contributors who will fill out this template to first read our 'definition document', and contact the coordinators if any further clarification is necessary.

Briefly, an archetype can be thought of as a model representing a causal mechanism, that is sufficiently abstracted as to be found in multiple case studies. Such model should capture the potential effects of specific external drivers and/or endogenous processes, which provide a partial explanation for specific trends have been observed in the case study. Therefore, such trends are an important component of the archetype identification procedure we are aiming at with this template. These trends might focus on change (or lack of) regarding land cover/use, land management, as well as associated socioeconomic and biophysical changes. Such changes might be deemed desirable or undesirable by the researchers.

Two important additional considerations on land system archetypes:

1) They can be though as generic building blocks of land system dynamics: one single archetype might be useful to understand and explain different case studies, but a single archetype is likely to cover a single case study only partially. In other words, single case study will likely require multiple archetypes to be comprehensively understood and to account for its major observed trends.

2) Importantly, the reference to 'causality' and 'generality' in this context does not suppose that such claim is yet supported empirically supported beyond doubt. While some archetypes might find support on widely documented empirical regularities and be directly based on established theory from economics, geography, ecology, or other disciplines in the field of land change science, other archetypes will have a more hypothetical character, stemming from informed propositions on the basis of case study expertise. 
Introduction for other potential contributors

This template is designed to summarize knowledge on recent and current trends of land systems change, and characterize multiple drivers underlying such change, based on expert-knowledge. We invite the description of case studies of land system dynamics in Latin America, with spatial scale ranging from the landscape level $\left(\sim 100 \mathrm{~km}^{2}\right)$ to subnational regions $\left(\sim 100.000 \mathrm{~km}^{2}\right)$, and covering any period between 1990 until today.

We are particularly interested in identifying potential causal mechanisms that drive land systems change, and hence can provide a partial explanation for the specific trends observed in the case study. These causal mechanisms might be external and endogenous processes, and the trends involve change (or lack of change) on land cover/use, land management, as well as associated socioeconomic and biophysical changes (e.g. agricultural labor arrangements and soil erosion). Such changes might be deemed desirable or undesirable by the researchers.

\section{LAND SYSTEM ARCHETYPES ELICITATION CASE STUDY TEMPLATE}

(Version 4: 2016.11.10)

The following color coding indicates the style of answer expected for each of the points in the template:

GREEN = Free text, paragraph style

BLUE = Free text, brief keywords or phrases

RED $=$ Choose from predefined keyword options

\section{Basic information}

1) Name of the case study

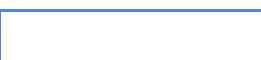

2) Contributors

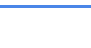

Case study expert(s) (this could be either the same contributors mentioned above, or 1-3 key authors of the key literature used by the contributors to fill out this template)

\section{Case study description}

3) Country (or countries, and any further jurisdictional specification, including coordinates if possible)

4) Geographical extent (select an option to indicate the order of magnitude in $\mathrm{km}^{2}$ )

- $\quad \sim 100 \mathrm{~km}^{2}$ (landscape, local watershed, or lower administrative level)

\footnotetext{
${ }^{1}$ Mention idea of founding one case study around one main author (for consistency), and the need to get experts to check this cases' descriptions
} 
- $\quad 1.000 \mathrm{~km}^{2}$ (e.g. most Natural Parks in South America)

- $\sim 10.000 \mathrm{~km}^{2}$ (particular region within a subnational region, e.g. Southern Yucatan Peninsula)

- $\quad 100.000 \mathrm{~km}^{2}$ (subnational region, e.g. La Pampa province, Argentina)

- $\sim 500.000 \mathrm{~km}^{2}$ (subcontinental region, e.g. South American Pampas)

5) Period covered

yyyy-yyyy

6a) Thematic focus of study (i.e. all of these themes are connected, but what was the main explicit focus of this research):

- Land use/cover change

- Ecosystem services provision

- Biodiversity change

- Agricultural practices (mainly agronomic aspects)

- Rural economic changes

- Other:

6b) Briefly, and in relation with the thematic focus/foci indicated in $6 a$, please state what is the main phenomenon your case study addressed (e.g. agricultural intensification; habitat loss; changing livelihood)

7) Dominant land use (area-wise), select multiple options if necessary:

- Small-scale crops (often, but not always for subsistence or local markets)

- Large-scale crops (commercial, beyond local markets)

- Extensive livestock (rangelands)

- Intensive livestock (feedlots)

- Forestry (managed forests or tree plantations)

- Extensive area mining

- (Semi)Wild ecosystems (conservation and/or tourism)

- Dense settlement

- Other: 


\section{Land system dynamics}

8) Briefly explain why this case study is interesting/relevant ${ }^{2}$, in relation to the theme(s) and land use(s) listed (points 6 and 7), and the spatio-temporal scale of analysis indicated (points 4 and 5).

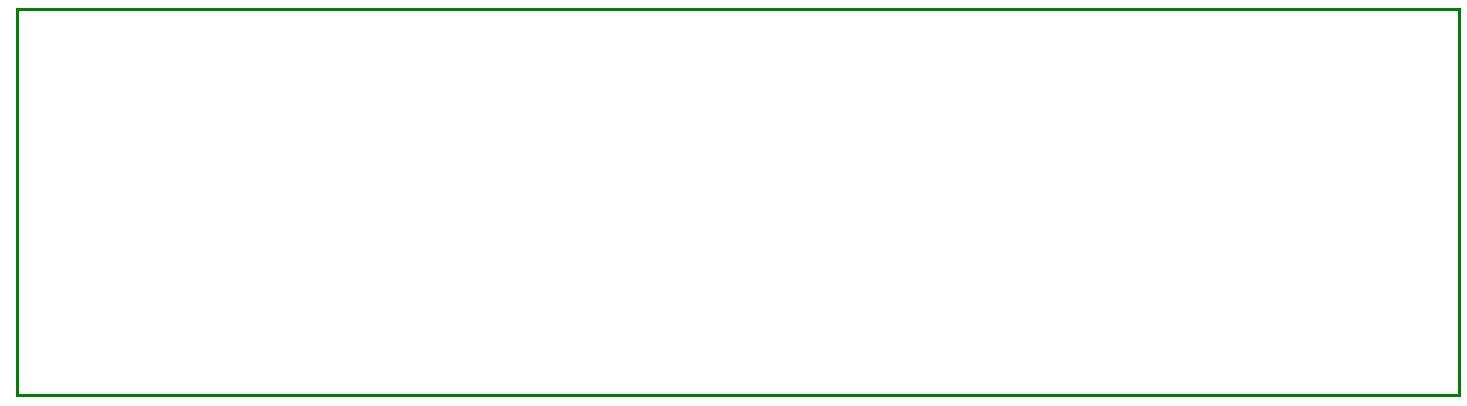

9) In relation with points 7, what do you think are the most important observed trends (in the period indicated on 5) that describe this case study? Use TABLE A to list and classify important changes (or lack of change).

10) How do you explain the above listed trends observed in your case study? For this question we distinguish between 10a) drivers and 11b) events.

10a) Drivers (considering the following distinction between exogenous and endogenous drivers, and use the TABLE B to organize the relevant information):

A. Drivers exogenous to the land dynamics of your case study, i.e. independent from land use/cover and management. Further, consider the distinction between global and national drivers:

- Global drivers (or globally relevant) (e.g. Chinese demand for soy)

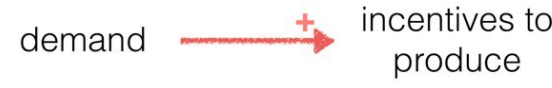

- National and Local drivers (e.g. national subsidies for fuel production)

subsidies

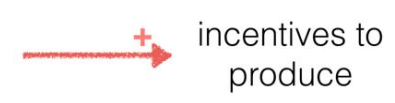

B. Drivers endogenous to the land dynamics of your case study, i.e. affected by the biophysical or socioeconomic processes that stem from land use/cover and land management. These can also be understood as:

- Feedback processes (e.g. reforestation in response to local scarcity of forest goods and services)

\footnotetext{
${ }^{2}$ This brief justification can be social (i.e. what happens in the place or situation is of social, economic, and/or political relevance), and/or the case is well-suited for measuring particular effects or exploring possible causal relationships with a more general academic interest.
} 


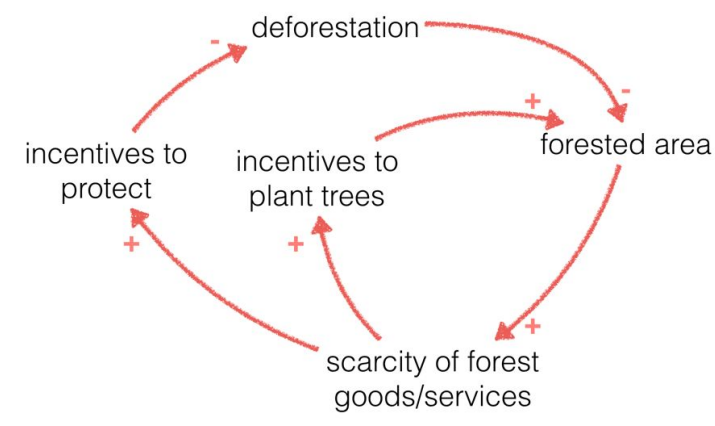

Once TABLE A and TABLE B are filled out, consider developing a simple graphical representation that synthesizes the way in which these drivers and observed trends are related in your case study. To build a simple causal-loop diagrams (as the ones sketched above), just keep in mind that arrows indicate a suggested causal influence in one direction, where a +arrow indicates that (all else being equal) change in the two linked variables goes in the same direction (positive relation), while a -arrow indicates that (all else being equal) the two linked variables change in opposite direction (negative relations). See example above.

10b) Events: (This point is optional) Is there any discrete event which crucially affected the land system of your case study in the period described? (i.e. events such as a radical change in political regime, financial collapse, or environmental catastrophe). Briefly describe how it relates to the trends (9) and drivers (10a) described above.

\section{Global}

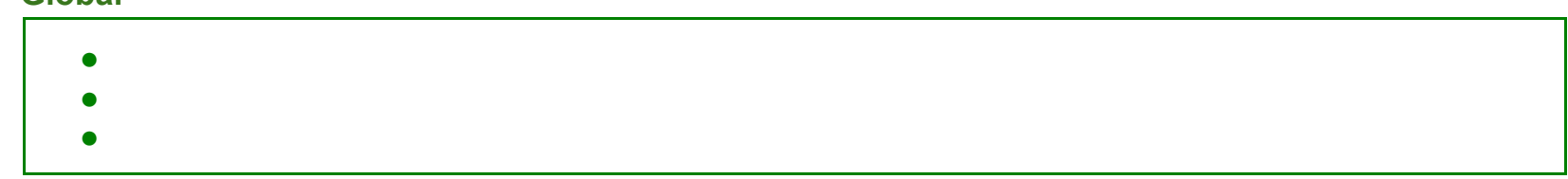

National

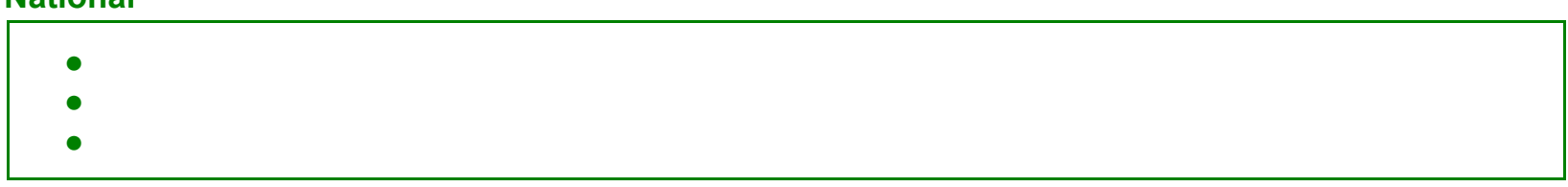

Local

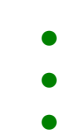

11) Please list all the references used to support the description of your case study in the sections above 
TABLE A

9a) In relation with point 7 , what do you think are the most important observed trends that describe this case study? Restrict this account to the period indicated on point 5. Use the table below to list and classify important changes (or lack of change) in this four domains: (Include literature references whenever possible)

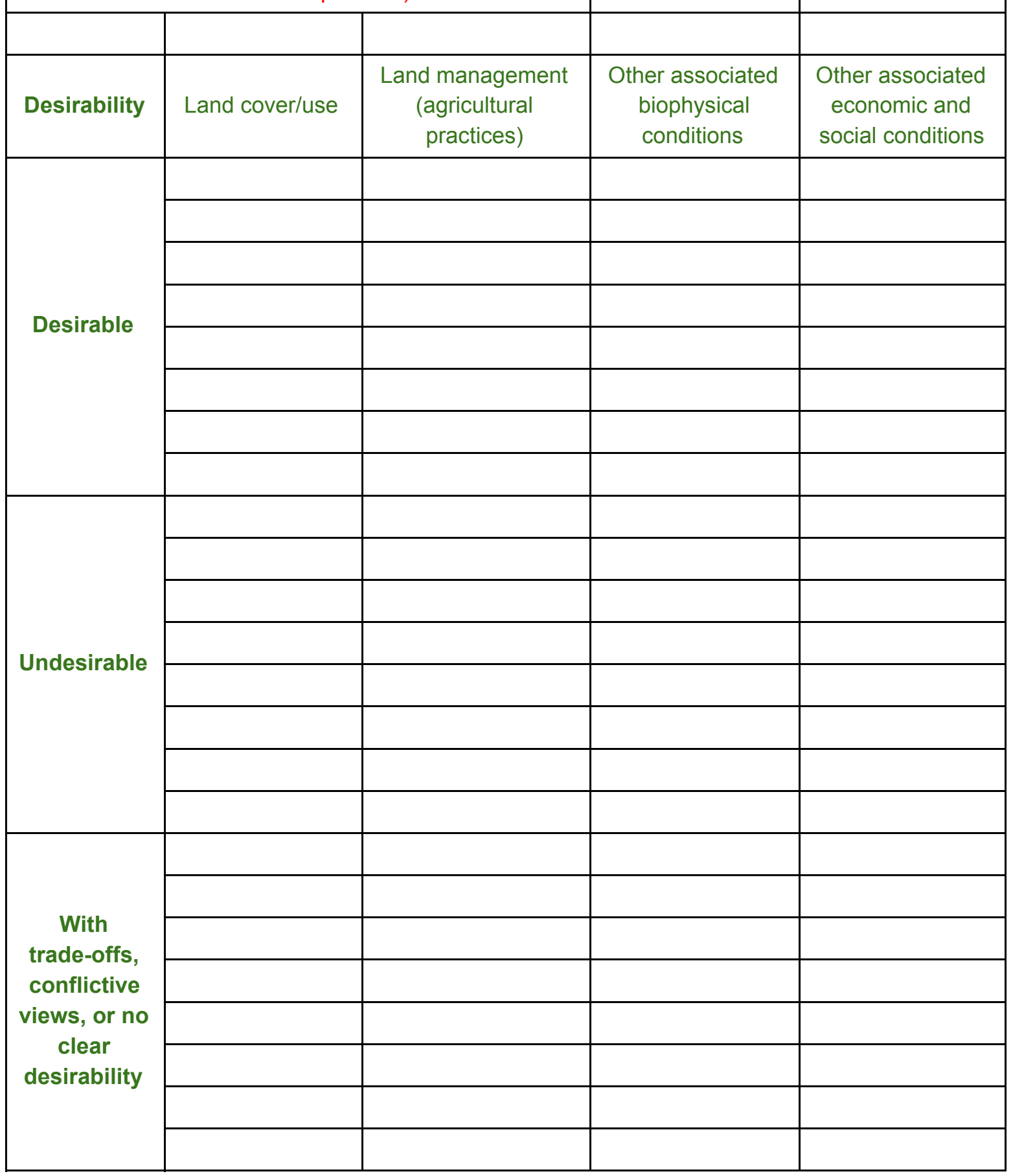


TABLE B

\begin{tabular}{|c|c|c|c|}
\hline How do you explair & the above listed tre & nds observed in your case study? & \\
\hline $\begin{array}{l}\text { 10a. Here, focus or } \\
\text { given their generic } \\
\text { historically specific } \\
\text { flagged on the colu }\end{array}$ & $\begin{array}{l}\text { drivers, which can } \\
\text { nature, as opposed } \\
\text { and can be listed in } \\
\text { mn headings with fu }\end{array}$ & $\begin{array}{l}\text { be described in a more stylized way } \\
\text { o events, which are likely to be more } \\
\text { section } 10 \mathrm{~b} \text {. (Note the comments } \\
\text { ther clarifications.) }\end{array}$ & \\
\hline & $\begin{array}{l}\text { Short name for the } \\
\text { driver or process }\end{array}$ & $\begin{array}{l}\text { Brief narrative explanation (Include } \\
\text { references whenever possible) }\end{array}$ & $\begin{array}{l}\text { Direct links to other } \\
\text { external drivers and } \\
\text { feedback processes? }\end{array}$ \\
\hline $\begin{array}{l}\text { Global driver } 1 \\
\text { (GD1) }\end{array}$ & & & \\
\hline $\begin{array}{l}\text { Global driver } 2 \\
\text { (GD2) }\end{array}$ & & & \\
\hline $\begin{array}{l}\text { Global driver } 3 \\
\text { (GD3) }\end{array}$ & & & \\
\hline $\begin{array}{l}\text { (Add more rows } \\
\text { as necessary) }\end{array}$ & & & \\
\hline $\begin{array}{l}\text { National or Local } \\
\text { Driver } 1 \text { (ND1) }\end{array}$ & & & \\
\hline $\begin{array}{l}\text { National or Local } \\
\text { driver } 2 \text { (ND2) }\end{array}$ & & & \\
\hline $\begin{array}{l}\text { National or Local } \\
\text { driver } 3 \text { (ND3) }\end{array}$ & & & \\
\hline $\begin{array}{l}\text { (Add more rows } \\
\text { as necessary) }\end{array}$ & & & \\
\hline $\begin{array}{l}\text { Feedback process } \\
1 \text { (FP1) }\end{array}$ & & & \\
\hline $\begin{array}{l}\text { Feedback process } \\
2 \text { (FP2) }\end{array}$ & & & \\
\hline $\begin{array}{l}\text { Feedback process } \\
3 \text { (FP3) }\end{array}$ & & & \\
\hline $\begin{array}{l}\text { (Add more rows } \\
\text { as necessary) }\end{array}$ & & & \\
\hline & & & \\
\hline
\end{tabular}




\section{Forest resurgence in post-war El Salvador}

\section{LAND SYSTEM ARCHETYPES ELICITATION \\ CASE STUDY TEMPLATE}

(Version 4: 2016.11.10)

The following color coding indicates the style of answer expected for each of the points in the template:

GREEN = Free text, paragraph style

BLUE $=$ Free text, brief keywords or phrases

RED $=$ Choose from predefined keyword options

\section{Basic information}

1) Name of the case study

Forest resurgence in post-war El Salvador

2) Contributors

Ariane de Bremond

Case study expert(s) (this could be either the same contributors mentioned above, or 1-3 key authors of the key literature used by the contributors to fill out this template) $)^{3}$

Ariane de Bremond, Doribel Herrador Valencia, Susana Hecht, Susan Kandel

\section{Case study description}

3) Country (or countries, and any further jurisdictional specification, including coordinates if possible)

El Salvador; northern ex-conflictive zones; area de conservacion Alto Lempa, municipality of Cinquera, Cabanas

4) Geographical extent (select an option to indicate the order of magnitude in $\mathrm{km}^{2}$ )

- $\quad \sim 100 \mathrm{~km}^{2}$ (landscape, local watershed, or lower administrative level)

- $\sim 1.000 \mathrm{~km}^{2}$ (e.g. most Natural Parks in South America)

- $\quad 10.000 \mathrm{~km}^{2}$ (particular region within a subnational region, e.g. Southern Yucatan Peninsula)

- $\quad 100.000 \mathrm{~km}^{2}$ (subnational region, e.g. La Pampa province, Argentina)

- $\sim 500.000 \mathrm{~km}^{2}$ (subcontinental region, e.g. South American Pampas)

5) Period covered

$1992-2006$

\footnotetext{
${ }^{3}$ Mention idea of founding one case study around one main author (for consistency), and the need to get experts to check this cases' descriptions
} 
6a) Thematic focus of study (i.e. all of these themes are connected, but what was the main explicit focus of this research):

- Land use/cover change

- Ecosystem services provision

- Biodiversity change

- Agricultural practices (mainly agronomic aspects)

- Rural economic changes

- Other

Civil conflict, forest resurgence/transition

6b) Briefly, and in relation with the thematic focus/foci indicated in 6a, please state what is the main phenomenon your case study addressed (e.g. agricultural intensification; habitat loss; changing livelihood)

The case study addresses the phenomenon of forest transition. In this case, the maintenance and protection of regenerated secondary forests between 1992- present by ex-combattants and returning refugees following the end of the Salvadoran civil war in 1991. A forest transition was brought about by cessation of cultivation of these lands during the Salvadoran civil war 1980-1992. Following the end of the war communities resettled these forested areas but renegotiated their land rights with the government to create and manage a protected area in the northern Alta Lempa region of El Salvador.

7) Dominant land use (area-wise), select multiple options if necessary:

- Small-scale crops (often, but not always for subsistence or local markets)

- Large-scale crops (commercial, beyond local markets)

- Extensive livestock (rangelands)

- Intensive livestock (feedlots)

- Forestry (managed forests or tree plantations)

- Extensive area mining

- (Semi)Wild ecosystems (conservation and/or tourism)

- Dense settlement

- Other:

(if not semi wild ecosystems -- really actually novel ecosystems (secondary regrowth during the war) now under conservation and tourism) but wild is ok too. 


\title{
Land system dynamics
}

8) Briefly explain why this case study is interesting/relevant ${ }^{4}$, in relation to the theme(s) and land use(s) listed (points 6 and 7), and the spatio-temporal scale of analysis indicated (points 4 and 5).

\begin{abstract}
In terms of land use/cover change, the study area of Cinquera is emblematic of forest resurgence (secondary forest growth as a result of natural recovery) which occurred throughout El Salvador during the civil war 1980-1992. In 1992, the Salvadoran Peace process mandated a land transfer program to ex-combatants and the displaced. The Cinquera area was resettled and rather than clearing their newly deeded lands, the ex-combatants and their families acted to form a community association, the Associacion de reconstrucción y desarollo de Cinquera (ARDM) and to consolidate their individual plots in low-lying areas and protect the forested area (also deeded lands) as one of their core priorities. Their deep attachment to the forest forged through the conflict became a reason to protect it, connecting them to their recent history and now constituting a part of their lives as a conservation area under local management. The area is also an important one for biodiversity protection in El Salvador, and constitutes an innovative model of participatory conservation. Outmigration during the war favoured forest regrowth but the area has been inhabited now for 25 years since the armed conflict and has essentially maintained its extension reflecting the protection but the organized local population. In addition to the civil war, forest regeneration resulting from reduced pressure on forests across EI Salvador is believed to be attributed to other socio-economic changes including: a sharp drop in agro-export production between 1970 and 2000 from $80 \%$ to $11 \%$ of foreign revenue and emigration (beginning with the civil war but continuing afterwards) with approximately $20 \%$ of households receiving remittances in 2013 . New policies including new forestry law with a role for co-management (brought about partially due to lobbying from Cinquera) are facilitating more participatory forms of conservation. While the story of Cinquera is quite unique and the land area relatively small (under $100 \mathrm{~km} 2$ ) it is nonetheless an example of one of the many community based conservation efforts going on in El Salvador and throughout the Latin American region.
\end{abstract}

9) In relation with points 7, what do you think are the most important observed trends (in the period indicated on 5) that describe this case study? Use TABLE A to list and classify important changes (or lack of change).

10) How do you explain the above listed trends observed in your case study? For this question we distinguish between 10a) drivers and 11b) events.

10a) Drivers (considering the following distinction between exogenous and endogenous drivers, and use the TABLE B to organize the relevant information):

A. Drivers exogenous to the land dynamics of your case study, i.e. independent from land use/cover and management. Further, consider the distinction between global and national drivers:

- Global drivers (or globally relevant) (e.g. Chinese demand for soy)

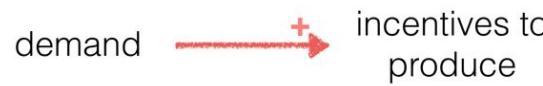

- National and Local drivers (e.g. national subsidies for fuel production)

\footnotetext{
${ }^{4}$ This brief justification can be social (i.e. what happens in the place or situation is of social, economic, and/or political relevance), and/or the case is well-suited for measuring particular effects or exploring possible causal relationships with a more general academic interest.
} 


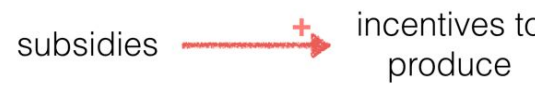

B. Drivers endogenous to the land dynamics of your case study, i.e. affected by the biophysical or socioeconomic processes that stem from land use/cover and land management. These can also be understood as:

- Feedback processes (e.g. reforestation in response to local scarcity of forest goods and services)

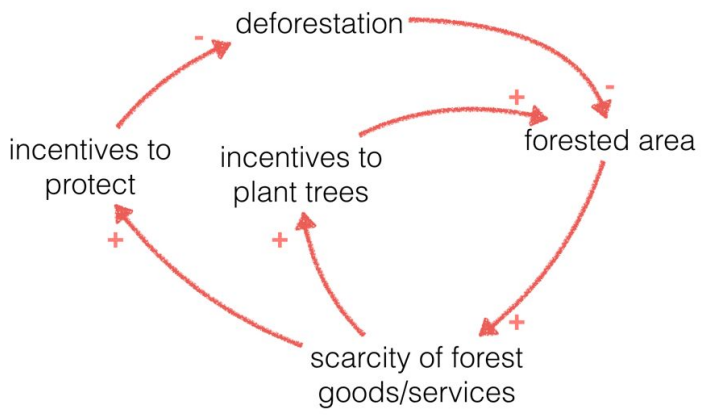

Once TABLE A and TABLE B are filled out, consider developing a simple graphical representation that synthesizes the way in which these drivers and observed trends are related in your case study. To build a simple causal-loop diagrams (as the ones sketched above), just keep in mind that arrows indicate a suggested causal influence in one direction, where a +arrow indicates that (all else being equal) change in the two linked variables goes in the same direction (positive relation), while a -arrow indicates that (all else being equal) the two linked variables change in opposite direction (negative relations). See example above. 


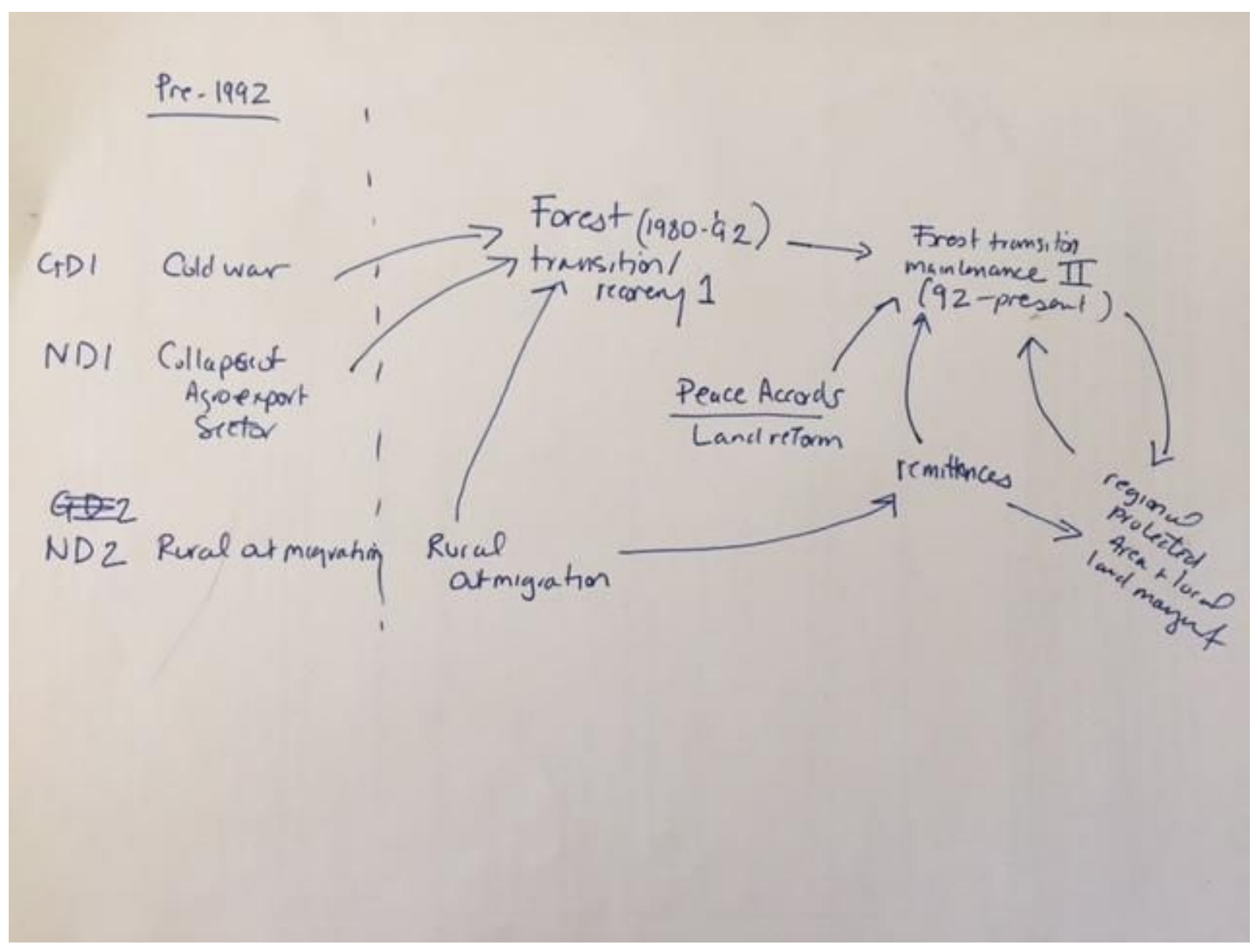

10b) Events: (This point is optional) Is there any discrete event which crucially affected the land system of your case study in the period described? (i.e. events such as a radical change in political regime, financial collapse, or environmental catastrophe). Briefly describe how it relates to the trends (9) and drivers (10a) described above.

\section{Global}

- Cold war/ US interventions in Central America -- drove the collapse of the Salvadoran economy and agro-export sector more specifically

\section{National}

- Civil war 1980-1992 - made rural work extremely dangerous and sparked out migration from the countryside to urban areas and abroad to flee the war.

\section{Local}

- Land change (forest transition) was a result of land abandonment as well as deliberate forest cover maintenance by the guerilla as the area was a crossroads for the north-south crossroads between various fronts of the war (North/Honduran border and coastal Fincas land.

11) Please list all the references used to support the description of your case study in the sections above 
de Bremond, A. (2006). Regenerating Conflicted Landscapes: Land, Environmental Governance, and Resettlement in Post-War El Salvador. Environmental Studies. Santa Cruz, University of California, Santa Cruz: 342.

de Bremond, A. (2009). The Politics of Peace and Resettlement through El Salvador's Land Transfer Programme: caught between the state and the market. Market-Led Agrarian Reform: Critical Perspectives on Neoliberal Land Policies and the Rural Poor. S. B. Jr, C. Kay and E. Lahiff. London; New York, Routledge.

de Bremond, A. (2013). "Harvesting Peace from Landscapes of Conflict: Land, Livelihoods, and Nature in Post-War El Salvador." Journal of Political Ecology( Special Issue: "Ecologies of Hope: The Prospect of New Development Hybrids").

Herrador Valencia, D., et al. (2011). "Tropical forest recovery and socio-economic change in El Salvador: An opportunity for the introduction of new approaches to biodiversity protection." Applied Geography 31(1): 259-268.

Valencia, D. H., et al. (2012). "Participatory Action Research Applied to the Management of Natural Areas: The Case Study of Cinquera in El Salvador." Journal of Latin American Geography 11(1): 45-65. 


\title{
Cattle ranching expansion and deforestation in paraguayan Chaco
}

\author{
LAND SYSTEM ARCHETYPES ELICITATION \\ CASE STUDY TEMPLATE \\ (Version 4: 2016.11.10)
}

The following color coding indicates the style of answer expected for each of the points in the template:

GREEN = Free text, paragraph style

BLUE $=$ Free text, brief keywords or phrases

RED $=$ Choose from predefined keyword options

\section{Basic information}

1) Name of the case study

Deforestation in the Paraguayan Chaco

2) Contributors

Matilda Baraibar

Case study expert(s) (this could be either the same contributors mentioned above, or 1-3 key authors of the key literature used by the contributors to fill out this template) $)^{5}$

Vallejos et al. 2015 (compilation and interpretation of remote sensing data of land use changes for the whole Chaco plain region, from the 1970s to 2015).

Caldas et al. 2017 (focusing on the processes and drivers behind land-cover change in the Paraguayan Chaco)

Py/SEAM/INFONA/FAPI 2016 (compilation of relevant public regulation in relation to land rights and forest conservation)

Human Rights Council. 2015 (consequences of the deforestation of th Paraguayan Chaco on indigenous communities living in the area)

\section{Case study description}

3) Country (or countries, and any further jurisdictional specification, including coordinates if possible)

The Chaco region of Paraguay; the department of Boquerón, Alto Paraguay, and the Department of Presidente Hayes

4) Geographical extent (select an option to indicate the order of magnitude in $\mathrm{km}^{2}$ )

- $\quad 100 \mathrm{~km}^{2}$ (landscape, local watershed, or lower administrative level)

- $\quad 1.000 \mathrm{~km}^{2}$ (e.g. most Natural Parks in South America)

- $\quad 10.000 \mathrm{~km}^{2}$ (particular region within a subnational region, e.g. Southern Yucatan Peninsula)

- $\quad 100.000 \mathrm{~km}^{2}$ (subnational region, e.g. La Pampa province, Argentina)

\footnotetext{
${ }^{5}$ Mention idea of founding one case study around one main author (for consistency), and the need to get experts to check this cases' descriptions
} 
- $\quad 500.000 \mathrm{~km}^{2}$ (subcontinental region, e.g. South American Pampas), $230.000 \mathrm{~km} 2$

\section{5) Period covered}

2002-2016

6a) Thematic focus of study (i.e. all of these themes are connected, but what was the main explicit focus of this research):

- Land use/cover change

- Ecosystem services provision

- Biodiversity change

- Agricultural practices (mainly agronomic aspects)

- Rural economic changes

- Other:

Land use and land cover change. Rapid rates of deforestation resulting in habitat loss; biodiversity loss, loss of carbon sinks and other ecosystem services, loss of livelihoods. Deforestation is mainly explained by cattle ranching expansion, which in turn is explained by high international beef demand and prices. This process has been spurred by the soybean expansion in other dry regions in South America. Cattle ranchers that have been "displaced" from traditional livestock land (by soybeans) have moved to the Paraguayan Chaco, where land prices still are significantly lower (nine times), land is fertile, labour and input costs are low, as well as taxes.

6b) Briefly, and in relation with the thematic focus/foci indicated in $6 a$, please state what is the main phenomenon your case study addressed (e.g. agricultural intensification; habitat loss; changing livelihood)

The Gran Chaco region, around $647,500 \mathrm{~km}^{2}$ of land distributed over northern Argentina, western Bolivia, south-western Brazil and Paraguay, has emerged as one of the world's most dramatic sites of deforestation, mainly due to agricultural expansion and intensification. This process is fairly recent. The forest of the Paraguayan Chaco (including the departments of Boquerón, Alto Paraguay, and of Presidente Hayes) had, up until the year 2000, remained rather intact (in contrast to the forests in eastern Paraguay, not least the Atlantic forest). From 2000, however, the deforestation has been fast, leading to loss of natural habitats and fragmentation of the landscape (Vallejos et al. 2015, 4, Graesser et al. 2015, Hansen et al. 2013).

Cattle ranching is a major driver of forest loss in this area (Imbach 2016). The pastureland expansion rates in the Paraguayan Chaco, between 2001 to 2013, were among the highest in Latin America (Graesser et al. 2015). Forest to pastureland conversion accounted for $62 \%$ of the 0.82 Mha of new pastureland from 2001 to 2013 (Baumann et al. 2016). In contrast to the deforestation processes in the Paraguayan Atlantic forest region, in the Argentinian Chaco or in the Amazon, soybean expansion has not been a driver of land-use and land-cover change in the Paraguayan Chaco. Actually, the area of perennial and annual crops decreased in the 
Paraguayan Chaco during the past decades (Caldas M 2017). However, the "soybean boom"; the rapid expansion of soybean area in other dry regions in South America; is still indirectly linked to the deforestation of Paraguayan Chaco. Cattle ranchers from areas in Argentina and Uruguay, where soybeans have to a large extent "displaced" pastures, have increasingly been buying land for cattle raising in the Paraguayan Chaco (Interviews by the author in February and March 2017 with IICA Paraguay, IICA Argentina, PNUD Paraguay, OPYPA Uruguay). The Paraguayan Chaco attracts the ranchers with low land prices, high productivity rates, low input, energy and labour costs, as well as with low fiscal pressure (Interviews by the author in February and March 2017 with IICA Paraguay, IICA Argentina, PNUD Paraguay, the Paraguayan vice-minister of agriculture, and the directos of OPYPA Uruguay).

In 2014, 287,000 hectares of forest were lost in the Paraguayan Chaco, and considering the strong economic drivers this is estimated to continuously be the annual rate of forest loss (transformed into pastures for cattle production) the coming years if nothing drastic changes (Imbach 2016, 6). This contrasts to the post-2007 slowdown of agricultural expansion into the Argentine Chaco and the Brazilian Amazon (Graesser et al. 2015).

The patterns of deforestation have been observed to be changing. Previously, small parcels of forest was gradually and solwly removed, while later satellite imagery shows a more regular, square pattern (Caldas M 2017). This suggests a change in technology, from chain saws or chaining to bulldozers and other heavy machinery for larger-scale clearing (Caldas M 2017). The remnants, of what was once an intact, diverse and widespread forest, become smaller, more isolated and less connected plots of land; a process of landscape fragmentation (Jobbágy et al. 2015, Vallejos et al. 2015, 6). The habitat loss and fragmentation that this land-use change is causing have important impacts on the ecosystems.

7) Dominant land use (area-wise), select multiple options if necessary:

- Small-scale crops (often, but not always for subsistence or local markets)

- Large-scale crops (commercial, beyond local markets)

- Extensive livestock (rangelands)

- Intensive livestock (feedlots)

- Forestry (managed forests or tree plantations)

- Extensive area mining

- (Semi)Wild ecosystems (conservation and/or tourism)

- Dense settlement

- Other:

Dry forest region, but increasing expansion of cattle grazing

\section{Land system dynamics}

8) Briefly explain why this case study is interesting/relevant ${ }^{6}$, in relation to the theme(s) and land use(s) listed (points 6 and 7), and the spatio-temporal scale of analysis indicated (points 4 and 5).

\footnotetext{
${ }^{6}$ This brief justification can be social (i.e. what happens in the place or situation is of social, economic, and/or political relevance), and/or the case is well-suited for measuring particular effects or exploring possible causal relationships with a more general academic interest.
} 
In Paraguay, rapid deforestation has in the past mainly taken place in the Eastern parts of the country, where nowadays few remnants remain of the once extensive Atlantic forest. The "modernization" impetus of Stroessner with public investments in infrastructure and promotion of export-oriented agriculture, resulted in that there has been a dramatic deforestation of the Atlantic forest since the 1970s (Baumann et al. 2016). The Paraguayan Chaco, in the western part of the country, was for long considered less attractive for agribusiness firms and investors than the Eastern part. The costs of production were higher as the Chaco was further away from export markets, the infrastructure was bad (increasing time and costs of transport) and the soils were less fertile. Thus, due to the harsh characteristics of the Paraguayan Chaco, it remained mainly "undeveloped", seemingly immune to large scale modern anthropogenic land modification

Immense forests dominated the landscape. The region was very sparsely populated, but nevertheless the home of several indigenous peoples, both nomadic hunters and gatherers and sedentary communities involved in different types of farming systems, including small-scale cropping and silvocultural grazing. During the 1920 s and 1930 s a significant amount of Mennonites settled in the region. They were given special rights and privileges and allowed to settle on indigenous lands, hiring their indigenous inhabitants as laborers (Human Rights Council 2015). In the 1960s, the Mennonites started to engage in more intensive farming activities and established milk producer cooperatives, and the Chaco became the most important region in the country for dairy production (Mereles and Rodas 2014). Extensive cattle ranching also begun to expand during the 1960s. The meat and dairy industry became the most important economic activities in the region (Caldas M 2017). It was not until recent years, however, that the meat and dairy enterprises begun to dramatically expand into the forest. Between 2000 and 2015, it is estimated that 5,5 millions of hectares of Paraguayan Chaco forest was lost, representing a reduction of the forest of more than $20 \%$ (Py/SEAM/INFONA/FAPI 2016, 9).

\section{Drivers:}

The main motor behind deforestation of the Paraguayan dry Chaco is big and extensive systems of farming and fattening of livestock (Py/SEAM/INFONA/FAPI 2016). Paraguayan livestock production has increased rapidly the past one and a half decade and the majority comes from the Chaco region. In the early years of the 2000s livestock production oscillated around 200.000 tons, while in 2014 it had more than doubled to 467.288 tons (See FAOSTAT: http://www.fao.org/faostat/en/\#data/QL). This in turn is explained by increased global demand of meat, as the majority of the Paraguayan cattle/beef production is exported (Service 2017). The international meat production and demand increased almost 20\% between 2005 and 2015 (OECD/FAO 2016, 107). As global food demand has increased, and as available arable land on a global scale is shrinking, the long-term prices on beef have been increasing. According to the OECD/FAO Agricultural Outlook, bovine meat prices have since 2000 had a period of continued, though at times volatile, increases (OECD/FAO 2016, 107-108). In addition, the government has made a great effort in the past years to open new markets in order to diversify exports. Paraguay currently has more than 80 markets open, and currently trades with more than 50 (Service 2017). The Chinese market, nevertheless, continues to be closed due to diplomatic issues. The work with sanitary and food safety improvement and to become free of Foot and Mouth Disease with vaccination and of negligible risk to BSE, have been important ingredients in getting access to new export markets (Service 2017). Senacsa (Paraguay's Animal Health Service) and other public entities work hard to meet increasingly higher requirements regarding control and sanitary status health, in order to open as many markets possible.

The low land prices of the Paraguayan Chaco, in combination with relative high beef prices, made livestock production increasingly profitable, in spite of the poorly developed infrastructure 
in the region and its remoteness from any international harbor. In addition, the government has started to invest heavily in infrastructure, especially highways, bridges and roads to connect the country in a more efficient way (Service 2017). Since 2016, the government is working with improvement of the National Route 9 (better known as Ruta Transchaco; known to have been in terrible shape for many years) which links el Chaco with the capital, Asunción (See information on the website for the Ministry of public constructions and communications http://www.mopc.gov.py/siguen-las-tareas-de-mantenimiento-de-la-ruta-9-n2773 See also FAO country Profile http://www.fao.org/faostat/en/\#country/169). This will probably significantly lower transport costs and time-cost, which in combination with high commodity prices, make agro-food production in el Chaco more profitable. In addition, the Paraguayan government allows the sector to operate freely and the fiscal pressure is low compared to Argentina and Uruguay. Accordingly, free enterprising, foreign direct investment promotion, low taxes, together with low land prices has attracted many foreign ranchers to the Paraguayan Chaco. The newly arrived foreign ranchers have typically sold their pastureland in Uruguay (and to a less extent Argentina) to soybean farmers for land prices that are around nine times higher per hectare than the prices in the Paraguayan Chaco, and therefore been able to buy bigger amounts of land (Interviews with IICA Paraguay and WWF Paraguay). In addition to low land prices, the foreign ranchers are attracted by the low fiscal pressure in Paraguay; approx. $10 \%$ of Value Added Tax (compared to $30 \%$ in Uruguay), $10 \%$ tax on rents (compared to $25 \%$ in Uruguay), no export taxes, no personal income tax (compared with a high a progressive income tax in Uruguay), low land taxes. Other pull factors are the higher fertility of the soils and the much lower production costs than in Uruguay and Argentina (input, labour, energy and gasoil). In particular the labour costs are low (the minimum wage is US\$370/month), and the Unions are weak and fragmented. ${ }^{7}$ Many of the foreign ranchers have "lost" (sold) land in their countries to soybean producers and expanded fast in the Paraguayan Chaco, mainly (CARTES, Thompson, and Yanosky 2015). There is also significant amount of internal "displacement" of farmers and ranchers in eastern Paraguay to the western Chaco. Among this group there are many Brazilian farmers that have been engaged in the agrarian production in the Eastern parts of Paraguay for many decades. The Menonites that have been living in the Chaco since the 1920 have also expanded their livestock activities, and own several prosperous beef and milk cooperatives (CARTES, Thompson, and Yanosky 2015). As of late 2016, Paraguay had 15 large slaughter plants eligible to export. The slaughter capacity of the export plants is calculated to increase from 1.6 million head in 2010 to 2.5 million head in 2017 (Service 2017). Most large plants are in hands of Brazilian capital, while Mennonite cooperatives operate 4 plants. These large plants produce roughly $75-80$ percent for export and the balance for the domestic market (Service 2017).

Population increase - The region is still very sparsely populated. The Paraguayan Arid Chaco forests represents a third of national territory, but less than $3 \%$ of the country's population

\footnotetext{
${ }^{7}$ See the following webb pages: "Uruguayos "colonizan" el chaco paraguayo: dos millones de hectáreas dedicadas a la ganadería pertenecen a inversores uruguayos" http://www.espectador.com/agro/258530/uruguayos-colonizan-el-chaco-paraguayo-dos-millones-de-h ectareas-dedicadas-a-la-ganaderia-pertenecen-a-inversores-uruguayos " Uruguayo en Paraguay: "La ganadería en el Chaco es un excelente negocio"'” http://www.elagro.com.py/ganaderia/uruguayo-en-paraguay-los-campos-producen-mas-carne-y-la-ec uacion-es-muy-favorable/ " Invertir en agricultura y ganadería en Paraguay" http://www.grupomonteclaro.com/invertir en paraguay.html "Paraguay es el nuevo "paraíso" para los inversores uruguayos" http://www.elpais.com.uy/economia/noticias/paraguay-nuevo-paraiso-inversores-uruguayos.html; Rafael Sorribas: "Los campos en Paraguay producen más carne y los costos son menores" http://rurales.elpais.com.uy/ganaderia/sorribas-los-campos-en-paraguay-producen-mas-carne-y-los-c ostos-son-menores (All accessed 2017-04-28)
} 
(Walcott 2014). Nevretheless,t from 1962 to 2002 the population increased from 74,129 to 135,186 people. Population increase can be an additional driver to deforestation (besides the exoanded beef production) as well as poor peasants using the forests as fire-wood (Caldas $\mathrm{M}$ 2017; Santagada 2013).

\section{Consequences of deforestation of the Paraguayan Chaco}

Until recently the Chaco remained one of the last intact extensive wilderness areas in Latin America, with only modest changes in the original forest cover. According to the National Forest Institute, INFONA, the Chaco forest in 2011 covered 11.561 .519 hectares of land, representing $60 \%$ of all Paraguayan forest land, and $28,4 \%$ of total Paraguayan land area. www.infona.gov.py/application/files/2114/3093/5539/BNB2011 6ESTRATOS.jpg While it still represents one of the world's largest forest reserves and unexploited (for agriculture) fertile land, the process of rapid agricultural expansion into the Paraguayan Chaco has already brought significant consequences (Vallejos et al. 2015, 7-8, Walcott 2014, Imbach 2016). The Chaco has been classified as of global and regional importance due to the existing diversity and endemism (Imbach 2016, 6). The Chaco forest is biologically diverse. However, pastures are gradually replacing the natural vegetation, resulting in an increased forest fragmentation (Walcott 2014, 15). Biodiversity strengthen several important ecosystem functions and habitat loss in the wake of deforestation in the Chaco is implying fragmentation with negative impacts on the biodiversity loss of exclusive species (ONU-REDD+/SEAM/INFONA/FAPI 2016, 3). Several plant and animal species in the Chaco are considered to be threatened of global extinction and the fragmentation and subsequent reduction of wildlife habitat results in a greater vulnerability of the endangered species (Walcott 2014, 18, Mereles and Rodas 2014). These forests have nevertheless often been considered without any economic value and when deforested the wood is often simply burned or set aside to compost (Walcott 2014, 4-5) .

The deforestation threatens the livelihoods of the communities living from the forest (Walcott 2014). The indigenous population in the Paraguayan Chaco is of approximately 40,000 , belonging to the native communities of Ayoreo, Chamacoco, Enxet, Nivakle, Manjuy, Maka'a, Toba Qom, Nandeva, and the Guarayo. The native communities use the forest for food, medicine and spiritual motives (Walcott 2014, 2). Given their reliance on their lands, they are extremely vulnerable to the land-use change (Interviews by the author with PNUD, 2017-02.19 and WWF Paraguay 2017-02.23). In this way, the loss of forests also means a decline of traditional knowledge. Some indigenous groups of the Chaco were traditionally living as nomads, and they coped with periods of local food shortage by moving to other areas. The privatization of land and the deforestation have made these groups increasingly food insecure (Walcott 2014, 31). One of the native groups living in the Paraguayan Chaco is the Ayoreo, of which some communities have chosen voluntary isolation from the outside world, and live in regions containing the ample supply of water and the richest biodiversity in the region, although it has remained poorly known (Yanosky 2013, 115-118). Also some Totobiegosode groups are isolated or in a situation of initial contact. The relentless spread of deforestation and the privatization of the territories where they live pose a strong threat to these groups. Many of the indigenous populations in the Chaco lack titles to their lands. There is a long history of disrespect for indigenous land rights in Paraguay. In the $19^{\text {th }}$ Century, the colonization of the Chaco was intense, and since independence 1811 successive authoritarian regimes confiscated indigenous lands (Human Rights Council 2015). Since the 1990s however, the Paraguayan constitution (adopted in 1992), and the Paraguayan ratification in 1993 of the International Labor Organization's Convention 169, provide indigenous people with relatively strong rights to land in order to be able to preserve and develop their ethnic identity in their own habitat. However, according to a UN report of the situation of indigenous peoples in Paraguay, one of the major problems facing the native groups is the lack of security of their rights to their lands, territories and resources (Human Rights Council 2015, 6). The livestock expansion in recent years is described to have exacerbated the violated rights of indigenous people to their land (Human Rights Council 2015). The Special Rapporteur of human rights reported the following: "Given the general situation in the country, the law appears to fall short of what is needed to ensure implementation of the constitutional and international standards relating to 
the rights of indigenous peoples. The legal framework suffers from conceptual shortcomings, as it characterizes land as no more than a productive resource without taking into account traditional land uses and the cultural and spiritual values that indigenous peoples associate with the land". According to information provided to the Special Rapporteur, the procedure for securing land titles is bureaucratic, difficult to follow and slow. The privatization of large amounts of land and the lack of a proper land registry have given rise to the existence of overlapping ownership deeds that serve as a basis for multiple claims to the same parcels. Conflicting claims are often settled in favor of business enterprises, thus depriving indigenous peoples of their lands. According to official sources, the expropriation process that should be followed in the case of indigenous land awards is often unworkable because of high land prices, and this situation often redounds to the benefit of private landowners. As a result, the issuance of land titles is frequently limited to non-contiguous parcels that are then broken up into lots which are often too small to be of practical use (Human Rights Council 2015, 6). There have been several legal processes regarding indigenous land in the Chaco, and some cases have been taken to the Corte Interamericana de Derechos Humanos (CortelDH Inter-American Court of Human Rights), that has ruled in favor of the rights of the indigenous groups to the land in El Chaco (Interview with WWF Paraguay in 2017).

The deforestation puts at threat several vital ecosystem services. One important ecosystem service of the Chaco forest is as climate regulator, because of its importance safeguarding the region's carbon stocks. Carbon emissions of the deforestation are substantial, and, if land-use changes continues, a highly significant amount of emissions of will be released and exacerbate global warming (Baumann et al. 2016, 11). In addition, the Paraguayan dry Chaco forests contribute to prevent water-induced soil erosion as well as wind erosion, and further deforestation could result in significant losses of the fertility of the soils (ONU-REDD+/SEAM/INFONA/FAPI 2016, 7; 13). Particularly the north-western parts of the Paraguayan Chaco are vulnerable for wind-erosion and consequently, deforestation in these areas lead to significant degradation and soil loss (ONU-REDD+/SEAM/INFONA/FAPI 2016, 14). In addition, the topography and forest cover of the Paraguayan dry Chaco decrease the discharge of sediments in the basins located in the western parts of the country, and therefore reduce the costs associated with dredging of navigable rivers (ONU-REDD+/SEAM/INFONA/FAPI 2016, 11). Another very high risk factor is that of soil salinization (Mereles and Rodas 2014).

It also seems like the new large scale farming systems that are expanding in the Chaco are less resilient to climate stress than traditional small-scale "campesino" systems. Large capitalized farming systems have more inter-annual variability in the primary production rates than "campesino" systems, which is probably explained by diverging risk strategies to cope with climatic fluctuations (Jobbágy et al. 2015). However, the large-scale rancher expansion, and the arrival of many foreign capitalized agribusiness firms, have also led to rapid productivity increases, technological transfer with incorporation of fences, better genetics, water reservoirs and pastures (Service 2017, CARTES, Thompson, and Yanosky 2015). The technological and know-how transfer brought by foreign ranchers have improved the nutrition and health management, the quality of the genetics, and increased the country's average weaning ratio. However, compared to countries like Argentina and Uruguay the weaning ratio is still around half of theirs (Service 2017). Paraguay has also increased its supply of premium chilled cuts with increased value added (Service 2017).

\section{Policy regulation and responses:}

The Paraguayan state has increasingly developed a regulatory framework to prevent the rapid deforestation and degradation of its forests, as well as offer economic incentives for afforestation and to restore forests in some places (Walcott 2014, 10, Piera Valdés 2016). The institutional capacity has been strengthening through the creation of the Environmental Protection Agency (SEAM) in 2004.

The most important legal regulations are the forestry law $422 / 73$ that declares of public interest 
and obligatory the protection, the conservation and the improvement of forest resources, and Law 536/94 to support afforestation and reforestation, as well as law 1639/2000 that modifies and deepens Law 536/94 (Piera Valdés 2016, 29; 59). Article 42 of law 422/73 stipulates that the forests has to be used in sustainable ways and all landowners with more than 20 hectares of forest need to leave at least $25 \%$ of the land aside for conservation and ecological rehabilitation. This means that landowners are required to keep at least a quarter of their properties forested, while they can legally deforest up to $75 \%$ of their land in the Paraguayan Chaco. There is nevertheless a widespread view that there is no penalty associated with not fulfilling the requirements of the law (Py/SEAM/INFONA/FAPI 2016, 36). Law 536 from 1995 increased the economic incentives (tax exonerations and cost reductions) for afforestation on soils that have been classified as suitable for forests, and law 1639/2000 prohibits to change land-use after having received benefits for afforestation (Piera Valdés 2016, 29-30; 63). Previous regulations that made it possible to confiscate unproductive "latifundio" land is changed I 2004 (No 2524), so that forest conservation cannot be defined as "unproductive" (Piera Valdés 2016, 30). In addition, during the 1990s, deeds against the environment became criminalized, previous Environmental Impact Analysis became obligatory for environmental change, the exports and traffic of Rolls, timber pieces and wooden beams become forbidden and Protected Wild life areas were established (Piera Valdés 2016, 25-33; 57-62). The state nevertheless lacks the capabilities to ensure compliance with environmental laws and regulations. The state is not managing to control the whole territory, said the Vice-Minister of Agriculture in an interview with the author (Interview with, Mario Leon, 2017-02-21).

Compliance with the legal framework is, at best, poor (Piera Valdés 2016, 33).

One of the main problems is in relation to land and unclear property rights. There is a widespread problem of legal contradictions, tensions and confusions between different types of property rights regimes. There are for example tensions between the communal land rights of native communities (art. 64 of the national constitution); the private property rights to land (art 109); the objectives of agrarian reform (art 114); the right of expropriation of unproductive "latifundio" (Art 115); and the wild life protected areas (law 352/95) (Santagada 2013, 13-14). There are important contradictions involved in different types of land rights. Besides the confusing status of property rights, with unclear rules, some land areas lack titles altogether, while other areas have various contradicting titles (Piera Valdés 2016, 33-35). Most of the dry Chaco Paraguayan forest is nevertheless clearly privately owned and for the most part it is to be found within the big land units (Py/SEAM/INFONA/FAPI 2016).

In addition, there is a lack of coordination between different public entities responsible for forest policies (Piera Valdés 2016, 25). Another severe problem is that when the property arrangements are clearly defined and legitimate, there is such widespread corruption at all levels that legal compliance and accountability are still often lost (Interviews with specialists working at PNUD Paraguay, 2017-02.19 and with specialists at IICA Paraguay, 2017-02-20).

For the Eastern part of the country, Paraguay legislated a moratorium of all deforestation until 2018, through the "Zero deforestation" (Law 2524 )

http://www.infona.gov.py/application/files/1714/2902/4900/Ley N 2524 - Deforestacion cero. pdf. While land-use change has continued in this area also after the new law, particularly in peasant camps, where the forest is used for firewood for both subsistence and sale, but also by agrarian firms because of the weakness of the state to enforce laws (Santagada 2013, 13-14). The law has nevertheless resulted in a substantial reduction in the rate of deforestation, from 110.000 ha in 2004 to approx. 9500 ha in 2008 (Walcott 2014, 10). There is a risk, however, that the strengthened regulatory framework to protect the forests in the already highly fragmented and deforested Eastern part of the country, has increased the pressures for deforestation of the dry Chaco forests (Walcott 2014, 10). A proposition to extend the zero-forestation law to the Chaco was rejected in the parliament.

Law No 3001/2006, from 2006 is an attempt to change the economic structure of incentives in favor of sustainable ecosystem management through payment schemes to ecosystem services. Landowners with more than 20 hectares and more than $25 \%$ of forest in their land can get certificates (environmental permits) for the environmental services that their forest provide (Py/SEAM/INFONA/FAPI 2016, 33). Firms involved in business activities of "high 
environmental impact" (roads, mining, etc) are obligated to compensate for their negative environmental impact by buying these certificates for environmental services

(Py/SEAM/INFONA/FAPI 2016, 33-35). Within this framework several studies have been mapping and quantifying the value of different ecosystem services provided by nature, and the dry Chaco has been identified as a region providing several vital environmental services (climate change mitigation; biodiversity conservation; soil and water protection (ONU-REDD+/SEAM/INFONA/FAPI 2016, 18, Py/SEAM/INFONA/FAPI 2016, 17-19). While law 3001/2006 opens up for payment for ecosystem services as economic incentives to avoid the on-going conversion of forests to pasture land, and while several studies show that it would be cost-effective to do so, it has still not implemented to any important extent. In 2016 , less than 25.000 hectares received some benefit from this regime, which represents only $8 \%$ of the area of forest annually lost in Paraguay (Py/SEAM/INFONA/FAPI 2016, 35). This is due to the lack of capacity of the state to enforce its regulations. In addition, it seems like these environmental certificates and permits issued by the Secretariat for the Environment (SEAM) sometimes do not conform to Paraguayan law or international standards relating to the rights of indigenous peoples (Human Rights Council 2015, 7). In this way, the unclear property right structure creates tensions and conflicts between different tools and ends regarding the Chaco forest.

The payments to landowners for environmental services can be combined with payments from the UN's "Reducing Emissions from Deforestation and Forest Degradation" REDD+, which could increase the incentives. In this respect, there is a lot of hope that the full implementation of REDD+ will lead to an important influx of institutional capacity and capital from abroad, which can allow for further push for conservation and afforestation in Paraguay (Piera Valdés 2016, 53,

Py/SEAM/INFONA/FAPI 2016). The high price on carbon seems to potentially offer landowners almost equal rents per hectare as provided by the livestock activities in the Paraguayan Chaco (Py/SEAM/INFONA/FAPI 2016, 15-17; 23-24; 28-29). One of the difficulties in implementing REDD+ in Paraguay is nevertheless the unclear property rights structure and legal framework, which results in unclear ownership of carbon, including who should receive the benefits of for example carbon credits within the framework of REDD+ (Piera Valdés 2016, 15-36). Those with clear land titles are mostly very big private landowners.

The land structure in Paraguay is very concentrated. According to the latest agrarian census (from 2008), $93.7 \%$ of the productive land is in the hands of only $8,6 \%$ of the productive units. Only $0,2 \%$ of all land units are bigger than 10.000 hectares, but these control $41 \%$ of all productive land in Paraguay. Most of the dry Chaco Paraguayan forest is nevertheless privately owned and for the most part it is to be found in the big land units (Py/SEAM/INFONA/FAPI 2016, 10-13). Accordingly carbon credits could exacerbate inequality and transfer more resources to the already rich, with no positive impact on poverty alleviation (Piera Valdés 2016, 34). This is badly aligned with the aim of REDD+ to not only reduce emissions from deforestation and forest degradation, but also to deliver additional social and environmental benefits with particular emphasis in generating opportunities for the most vulnerable communities (ONU-REDD+/SEAM/INFONA/FAPI 2016). However, the fact that the majority of the Chaco forest is in the hands of relatively few landowners also reduces transaction costs and is considered as a factor that potentially can make efforts to stop deforestation more effective (Py/SEAM/INFONA/FAPI 2016, 13). In addition, the rents of the extensive livestock activity that is the main cause behind deforestation of the Paraguayan Chaco are rather low per hectare (which is compensated by the vast size of the land units), which implies a low opportunity cost for forest conservation (possible to cover by payment schemes on for example carbon on other ecosystem services). 
There are also an increasing number of Protected Areas to ensure forest conservation and create biological corridors to superpose some of the negative impacts brought by the fragmentation (Walcott 2014, 44) - Law 352/94 Sistema Nacional de Áreas Silvestres Protegidas - SINASIP, SEAM-PNUD. The biggest Protected Area in the Chaco is the National Park "Defensores del Chaco" of 780,000 hectares. For this vast region, however, only a single ranger is assigned, and there is a complete lack of logistical and financial support for that ranger, and accordingly the establishment of Protected Areas have not spared these lands from massive deforestation (Human Rights Council 2015). Another problem is that the legal authority over these areas is ambiguous. In addition, they are not exactly defined and delineated, which has resulted in settlers installing themselves at their borders (Santagada 2013).

In general the Paraguayan state has a series of initiatives to protect the forests and the National Development Plan of Paraguay 2030 (from 2014) stipulates targets of restoring at least $20 \%$ of degraded ecosystems, increase the forest cover and protect the biomass area and increase income from selling environmental services (Imbach 2016, 6). However, the special rapporteur on human rights noted that the National Development Plan does not refer specifically to indigenous peoples or to their rights, and the main development model seems to continuously promote economic growth over other ends (Human Rights Council 2015, 14). Many of the public policies and the low agrarian fiscal pressure, in combination with the institutional weakness, rather support further livestock agribusiness expansion and other commodity export sectors (Human Rights Council 2015, 12). In addition, the lack of spatial planning, the gross breaches of existing laws and regulations, the overlaps and gaps in legislation and the severe institutional weaknesses, make the future look less bright for the forest conservation (Py/SEAM/INFONA/FAPI 2016, 9).

9) In relation with points 7 , what do you think are the most important observed trends (in the period indicated on 5) that describe this case study? Use TABLE A to list and classify important changes (or lack of change).

10) How do you explain the above listed trends observed in your case study? For this question we distinguish between 10a) drivers and 11b) events.

10a) Drivers (considering the following distinction between exogenous and endogenous drivers, and use the TABLE B to organize the relevant information):

A. Drivers exogenous to the land dynamics of your case study, i.e. independent from land use/cover and management. Further, consider the distinction between global and national drivers:

- Global drivers (or globally relevant) (e.g. Chinese demand for soy)

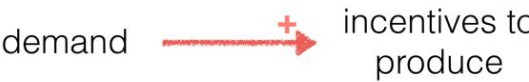

- National and Local drivers (e.g. national subsidies for fuel production)

subsidies incentives to
produce

B. Drivers endogenous to the land dynamics of your case study, i.e. affected by the biophysical or socioeconomic processes that stem from land use/cover and land management. These can also be understood as: 
- $\quad$ Feedback processes (e.g. reforestation in response to local scarcity of forest goods and services)

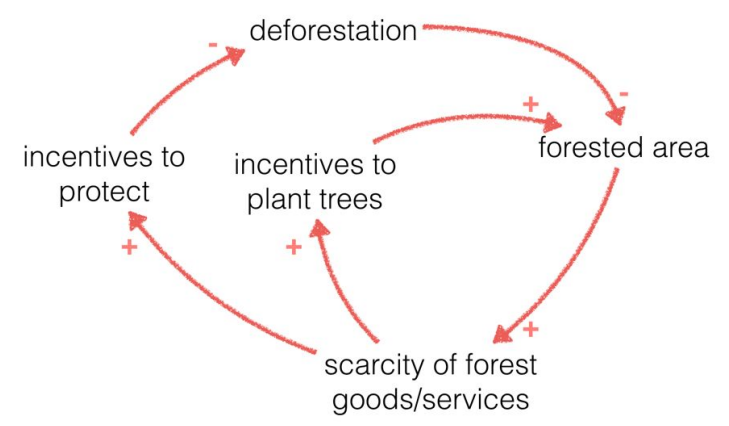

Once TABLE A and TABLE B are filled out, consider developing a simple graphical representation that synthesizes the way in which these drivers and observed trends are related in your case study. To build a simple causal-loop diagrams (as the ones sketched above), just keep in mind that arrows indicate a suggested causal influence in one direction, where a +arrow indicates that (all else being equal) change in the two linked variables goes in the same direction (positive relation), while a -arrow indicates that (all else being equal) the two linked variables change in opposite direction (negative relations). See example above.

10b) Events: (This point is optional) Is there any discrete event which crucially affected the land system of your case study in the period described? (i.e. events such as a radical change in political regime, financial collapse, or environmental catastrophe). Briefly describe how it relates to the trends (9) and drivers (10a) described above.

\section{Global}

- Increased international demand and high prices of meat, 2000-2015

- Financialized agribusiness firms and other investors searching for new markets; expanding into the markets of land and agriculture

- Cattle farmers from other countries, Argentina, Uruguay and Brazil, searched for new land for pastures, as they had lost land to crop cultivations, in the wake the increased competition for land caused by the soya-boo..

\section{National}

- The "Zero deforestation" law (no. 2524) from 2004 made all deforestation in the Eastern part of the country illegal. This increased the pressures for deforestation in the Paraguayan Chaco

- The government has been investing in infrastructure improvement, such as roads and electricity. The animal halth control system has been significantly reinforced, not least in respect to Foot and Mouth Disease

- The National Development Plan of Paraguay 2030 (from 2014) and the planned future implementation of REDD+ payment schemes for ecosystem services (post- 2017).

\section{Local}

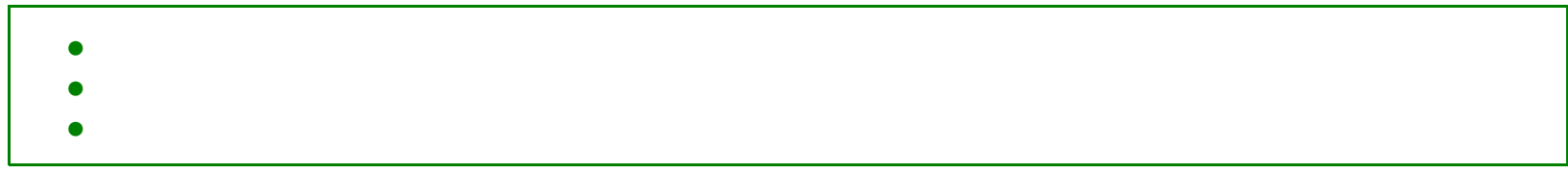

11) Please list all the references used to support the description of your case study in the sections above 
Baumann, Matthias, Ignacio Gasparri, María Piquer-Rodríguez, Gregorio Gavier Pizarro, Patrick Griffiths, Patrick Hostert, and Tobias Kuemmerle. 2016. "Carbon emissions from agricultural expansion and intensification in the Chaco." Global change biology.

Caldas M, Goodin D, Sherwood S, Campos Krauer J, Wisely S. . 2017. "Land-cover change in the Paraguayan Chaco: 2000-2011." Journal Of Land Use Science no. 10 (1):1-18.

CARTES, JOSÉ L, JJ Thompson, and A Yanosky. 2015. "El Chaco paraguayo como uno de los últimos refugios para los mamíferos amenazados del Cono Sur." Paraquaria Natural no. 3 (2):37-47.

Graesser, Jordan, T Mitchell Aide, H Ricardo Grau, and Navin Ramankutty. 2015. "Cropland/pastureland dynamics and the slowdown of deforestation in Latin America." Environmental Research Letters no. 10 (3):034017.

Hansen, Matthew C, Peter V Potapov, Rebecca Moore, Matt Hancher, SA Turubanova, Alexandra Tyukavina, David Thau, SV Stehman, SJ Goetz, and TR Loveland. 2013. "High-resolution global maps of 21st-century forest cover change." Science no. 342 (6160):850-853.

Human Rights Council. 2015. Report of the Special Rapporteur on the rights of indigenous peoples, Victoria Tauli-Corpuz, Addendum The situation of indigenous peoples in Paraguay. In Human Rights Council, Thirtieth session, Agenda item 3: Inited Nations -General Assembly.

Imbach, P., Robalino, J., Zamora, J., Brenes, C., Sandoval, C., Pacay, E., Cifuentes-Jara, M., Labbate, G. 2016. Escenarios de deforestación futura en Paraguay. edited by FAO/PNUD/PNUMA. Asunción: PNC ONU-REDD+ Py/SEAM/INFONA/FAPI.

Jobbágy, E. G., H. R. Grau, J. M. Paruelo, and E. F. Viglizzo. 2015. "Farming the Chaco: Tales from both sides of the fence." Journal of Arid Environments no. 123:1-2. doi: http://dx.doi.org/10.1016/j.jaridenv.2015.07.011.

Mereles, María Fátima, and Oscar Rodas. 2014. "Assessment of rates of deforestation classes in the Paraguayan Chaco (Great South American Chaco) with comments on the vulnerability of forests fragments to climate change." Climatic Change no. 127 (1):55-71. doi: 10.1007/s10584-014-1256-3.

OECD/FAO. 2016. OECD-FAO Agricultural Outlook 2016-2025,. Paris: Economic and Social Development Department, .

ONU-REDD+/SEAM/INFONA/FAPI, PNC. 2016. Mapeo de los benificios múltiples de REDD+ en Paraguay: analisís adicionales para orientar la toma de decisiones sobre políticas y medidas REDD+. edited by Programa de las Naciones Unidas para el Medio Ambiente. Asunción: FAO/PNUD/PNUMA.

Piera Valdés, A. 2016. Consultoría Nacional: Análisis del Marco Legal e Institucional Vigente para la Implementación de REDD+ en Paraguay. In Program ONU-REDD+ Paraguay. Asunción: FAO, PNUD, PUMA, INFONA, SEAM, FAPI.

Py/SEAM/INFONA/FAPI, PNC ONU-REDD+. 2016. Paraguay: cambio de uso e suelo y costos de oportunidad. Sinergias entre REDD+ y la Ley de Valoración y Retribución de Servicios Ambientales. Ciudad de Panama: FAO/PNUD/PNUMA.

Santagada, E. 2013. Reporte sobre la problemática de la tenencia de la tierra en el Paraguay de cara a la implementación del Programa REDD+. edited by ONU - REDD PNC Paraguay. Asunción: Programa de Naciones Unidas para el Medio Ambiente (PNUMA)

Service, USDA Foreign Agricultural. 2017. Paraguay: Livestock and Products Annual, 2016. In GAIN report, edited by GAIN Publications: USDA.

Walcott, J., Thorley J., Casco, G,. Coronel, L., Kapos, V., Miles, L., Blaney, R \& Woroniecki S. 2014. Mapeo de los beneficios múltiples de REDD+ en Paraguay: el uso de la información espacial para apoyar la planificación del uso de la tierra. Cambridge: Programa de las Naciones Unidas para el Medio Ambiente.

Vallejos, M. J., Volante, N., Mosciaro, M., Vale, M., Bustamante, L and Paruelo, L. 2015. 
"Transformation dynamics of the natural cover in the Dry Chaco ecoregion: A plot level geo-database from 1976 to 2012." Journal of Arid Environments no. 123:3-11. doi: http://dx.doi.org/10.1016/j.jaridenv.2014.11.009.

Yanosky, A. 2013. "Paraguay's, challenge of conserving natural habitats and biodiversity with global markets demanding for products." In Conservation biology: voices from the tropics., edited by Gibson, L., Navjot, S., Sodhi, and Raven, P. 113-119. Asunción: Wiley and Sons. 


\title{
Eco-certification of coffee in Santander, Colombia
}

\author{
LAND SYSTEM ARCHETYPES ELICITATION \\ CASE STUDY TEMPLATE \\ (Version 4: 2016.11.08)
}

The following color coding indicates the style of answer expected for each of the points in the template:

GREEN = Free text, paragraph style

BLUE = Free text, brief keywords or phrases

RED $=$ Choose from predefined keyword options

\section{Basic information}

1) Name of the case study

Eco-certification on coffee landscapes (Santander, Colombia)

2) Contributors (who is filling out this template?)

Daniel Ospina, Juan Carlos Rocha

Case study expert(s) (this could be either the same contributors mentioned above, or 1-3 key authors of the key literature used by the contributors to fill out this template) ${ }^{8}$

Ximena Rueda, Eric Lambin (Rueda and Lambin 2013a,b; Rueda et al. 2015)

\section{Case study description}

3) Country (or countries, and any further jurisdictional specification, including coordinates if possible)

Upper Suárez river watershed (Santander), in the eastern Andes in Colombia

4) Geographical extent (select an option to indicate the order of magnitude in $\mathrm{km}^{2}$ )

- $\quad 100 \mathrm{~km}^{2}$ (landscape, local watershed, or lower administrative level)

- $\quad 1.000 \mathrm{~km}^{2}$ (e.g. most Natural Parks in South America)

- $\quad 10.000 \mathrm{~km}^{2}$ (particular region within a subnational region, e.g. Southern Yucatan Peninsula)

- $\sim 100.000 \mathrm{~km}^{2}$ (subnational region, e.g. La Pampa province, Argentina)

- $\sim 500.000 \mathrm{~km}^{2}$ (subcontinental region, e.g. South American Pampas)

5) Period covered

2003-2010

6a) Thematic focus of study (i.e. all of these themes are connected, but what was the main explicit focus of this research):

${ }^{8}$ Mention idea of founding one case study around one main author (for consistency), and the need to get experts to check this cases' descriptions 
- Land use/cover change

- Ecosystem services provision

- Biodiversity change

- Agricultural practices (mainly agronomic aspects)

- Rural economic changes

- Other:

6b) Briefly, and in relation with the thematic focus/foci indicated in 6a, please state what is the main phenomenon your case study addressed (e.g. agricultural intensification; habitat loss; changing livelihood)

Three main interrelated phenomena on this case study are 1) certification by small-holder farmers as an adaptation to changes in the global coffee market, 2) transmission of value from environmentally-minded consumers to farmers though the whole value-chain, and 3) forest cover increase and other environmental outcomes driven by certification.

7) Dominant land use (area-wise), select multiple options if necessary:

- Small-scale crops (often, but not always, for subsistence or local markets)

- Large-scale crops (commercial, beyond local markets)

- Extensive livestock (rangelands)

- Intensive livestock (feedlots)

- Forestry (managed forests or tree plantations)

- Extensive area mining

- (Semi)Wild ecosystems (conservation and/or tourism)

- Dense settlement

- Other:

\section{Land system dynamics}

8) Briefly explain why this case study is interesting/relevant ${ }^{9}$, in relation to the theme(s) and land use(s) listed (points 6 and 7), and the spatio-temporal scale of analysis indicated (points 4 and 5).

This case study is important because it assesses the extent to which the expectations that underlie the use of eco-certifications for agricultural commodities actually do reflect in observable significant changes in the rural landscapes/ecosystems and the well-being of rural households. Research by Rueda and her colleagues on this case study provides some insights to understand why farmers join and stay in certification programs, going beyond the expected monetary benefits. Additionally, part of this research presents the first evaluation of the impacts of eco-certification in cultivated landscapes at the ecosystem level, based on satellite imagery and geo-referenced plot information. In doing so, the authors contribute to understanding a different 'pathway' of forest transition that goes beyond the explanations that hinge on secondary forest regrowth on abandoned farmlands

\footnotetext{
${ }^{9}$ This brief justification can be social (i.e. what happens in the place or situation is of social, economic, and/or political relevance), and/or the case is well-suited for measuring particular effects or exploring possible causal relationships with a more general academic interest.
} 
following rural out-migration, or tree plantations in response to forest scarcity. Understanding the effect that this type of international tele-connection, linking consumers in high income countries with producers in middle and low income countries, is crucial for informing policies that foster transitions towards more sustainable socio-ecological interactions.

9) In relation with points 7, what do you think are the most important observed trends (in the period indicated on 5) that describe this case study? Use TABLE A to list and classify important changes (or lack of change).

10) How do you explain the above listed trends observed in your case study? For this question we distinguish between 10a) drivers and 11b) events.

10a) Drivers (considering the following distinction between exogenous and endogenous drivers, and use the TABLE B to organize the relevant information):

A. Drivers exogenous to the land dynamics of your case study, i.e. independent from land use/cover and management. Further, consider the distinction between global and national drivers:

- Global drivers (or globally relevant) (e.g. Chinese demand for soy)

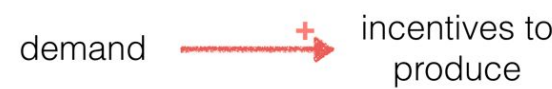

- National and Local drivers (e.g. national subsidies for fuel production)

subsidies

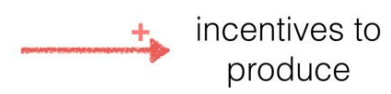

B. Drivers endogenous to the land dynamics of your case study, i.e. affected by the biophysical or socioeconomic processes that stem from land use/cover and land management. These can also be understood as:

- $\quad$ Feedback processes (e.g. reforestation in response to local scarcity of forest goods and services)

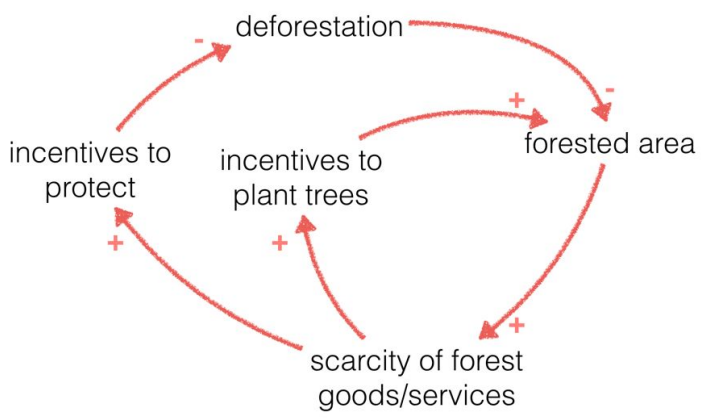

Once TABLE A and TABLE B are filled out, consider developing a simple graphical representation that synthesizes the way in which these drivers and observed trends are related in your case study. To build a simple causal-loop diagrams (as the ones sketched above), just keep in mind that arrows indicate a suggested causal influence in one direction, where a +arrow indicates that (all else being equal) change in the two linked variables goes in the same direction (positive relation), while a -arrow indicates that (all else being equal) the two linked variables change in opposite direction (negative relations). See example above. 
10b) Events: (This point is optional) Is there any discrete event which crucially affected the land system of your case study in the period described? (i.e. events such as a radical change in political regime, financial collapse, or environmental catastrophe). Briefly describe how it relates to the trends (9) and drivers (10a) described above.

Global

- Rueda and Lambin (2013b): The International Coffee Agreement (ICA) between producing and importing countries came to an end in 1989 when countries failed to agree on the export quotas that had kept prices relatively stable for over 30 years (Daviron \& Ponte, 2005; Muradian \& Pelupessy, 2005).

- In 2004, coffee certification went mainstream with Procter and Gamble and Kraft foods launching RFA-certified products for particular markets (RFA 2012).

$\bullet$

National

$\bullet$

$\bullet$

$\bullet$

Local

- Rueda and Lambin 2013a: In 2002 the Rainforest Alliance officers visited local farms and helped formalize a sales agreement with one of the largest coffee roasters. FNC's extension service, together with farmers and auditors, worked to translate the SAN protocol into applicable actions in the local context.

$\bullet$

$\bullet$

11) Please list all the references used to support the description of your case study in the sections above

Daviron, B., \& Ponte, S. (2005). The coffee paradox: Global markets, commodity trade and the elusive promise of development. Ede, Netherlands: Zed Books in association with the CTA.

FNC (2011). Commercial statistics. Federación Nacional de Cafeteros de Colombia. Bogota.

Giovannucci, D., and S. Ponte. 2005. Standards as a new form of social contract? Sustainability initiatives in the coffee industry. Food Policy 30:284-301.

Giovannucci, D., Pierrot, J., \& Kasterine, A. (2010). Trends in the trade of certified coffees. Retrieved from <http://mpra.ub.uni-muenchen.de/ 27551/>

Guhl A (2009) Café, bosques y certificación agrícola en Aratoca, Santander. Revista de estudios sociales $32: 114-125$

Muradian, R., \& Pelupessy, W. (2005). Governing the coffee chain: The role of voluntary regulatory systems. World Development, 33(12), 2029-2044.

Rainforest Alliance (RFA). 2011. The Rainforest Alliance demonstrates significant growth in 2011. Rainforest Alliance, New York, New York, USA. http://www.rainforest-alliance.

org/newsroom/news/annual-growth-2011 
Rainforest Alliance (RFA). 2012. The Rainforest Alliance certified TM difference: sustainable agriculture certification. The Rainforest Alliance, New York, New York, USA. http://

www.rainforest-alliance.org/sites/default/files/publication/pdf/ ag_cert_difference_en_hz_jan10.pdf

Ramirez, L., Silva, G., Valenzuela, L., Villegas, A., \& Villegas, L. (2002). El Café , Capital Social

Estratégico. Bogotá: Comisión de Ajuste de la Institucionalidad Cafetera.

Reina, M., G. Silva, L. F. Samper, and M. d. P. Fernandez. 2008. Juan Valdez: strategy behind the brand. Ediciones B, Bogotá, Colombia.

Rueda, X., and E. F. Lambin. 2013a. Responding to Globalization: Impacts of Certification on Colombian Small-Scale Coffee Growers. Ecology and Society 18:art21.

Rueda, X., and E. F. Lambin. 2013b. Linking Globalization to Local Land Uses: How Eco-Consumers and Gourmands are Changing the Colombian Coffee Landscapes. World Development 41:286-301.

Rueda, X., N. E. Thomas, and E. F. Lambin. 2015. Eco-certification and coffee cultivation enhance tree cover and forest connectivity in the Colombian coffee landscapes. Regional Environmental Change 15:25-33.

Sánchez-Cuervo AM, Aide T, Clark M, Etter A (2012) Land cover change in Colombia: surprising forest recovery trends between 2001 and 2010. PLoS ONE 7(8):e43943

Swinnen, J. F. M., A. Vandeplas, and M. Maertens. 2010. Liberalization, endogenous institutions, and growth: a comparative analysis of agricultural reforms in Africa, Asia, and Europe. World Bank Economic Review 24:412-445.

United States Department of Agriculture (USDA). 2011. Production, supply and distribution online. United States Department of Agriculture, Foreign Agricultural Service, Washington, D.C., USA. [online] URL: http://www.fas.usda. gov/psdonline/

Zimmerer, K. S. 2007. Agriculture, livelihoods, and globalization: the analysis of new trajectories (and avoidance of just-so stories) of human-environment change and conservation. Agriculture and Human Values 24:9-16. 


\title{
Rural out-migration and farm abandonment in the Pará, Brazil
}

\author{
LAND SYSTEM ARCHETYPES ELICITATION \\ CASE STUDY TEMPLATE \\ (Version 4: 2016.11.10)
}

The following color coding indicates the style of answer expected for each of the points in the template:

GREEN = Free text, paragraph style

BLUE $=$ Free text, brief keywords or phrases

RED $=$ Choose from predefined keyword options

\section{Basic information}

1) Name of the case study

Recent rural out migration and abandonment of farming practices in the Central Brazilian Amazon

2) Contributors

J.S. Oestreicher, PhD.

Case study expert(s) (this could be either the same contributors mentioned above, or 1-3 key authors of the key literature used by the contributors to fill out this template) ${ }^{10}$

Rozon et al., 2014; Oestreicher et al., 2014; Oestreicher et al., in press

\section{Case study description}

3) Country (or countries, and any further jurisdictional specification, including coordinates if possible)

Area of influence: Santarém-Cuiabá and Transamazon highways (BR-163 \& BR-230).

Municipalities: Aveiro and Ruropolis.

Tapajós River Region, State of Pará, Brazil.

Coordinates for the city of Itaituba: $04^{\circ} 28^{\prime} \mathrm{S}, 55^{\circ} 99^{\prime} \mathrm{W}$

Community of Nova Estrela

4) Geographical extent (select an option to indicate the order of magnitude in $\mathrm{km}^{2}$ )

- $\quad \sim 100 \mathrm{~km}^{2}$ (landscape, local watershed, or lower administrative level)

5) Period covered

$2008-2015$

6a) Thematic focus of study (i.e. all of these themes are connected, but what was the main explicit

${ }^{10}$ Mention idea of founding one case study around one main author (for consistency), and the need to get experts to check this cases' descriptions 
focus of this research):

- Land use/land cover (forest transitions)

- Other:

rural-urban migration

6b) Briefly, and in relation with the thematic focus/foci indicated in 6a, please state what is the main phenomenon your case study addressed (e.g. agricultural intensification; habitat loss; changing livelihood)

This particular case study documents rural out migration and secondary forest regrowth in the community of Nova Estrela (figure 1). I am currently analyzing the changes in social network structures to understand how rural out migration is related to farm abandonment. The intention is to contribute to the literature on forest transitions and tropical urbanization processes.

7) Dominant land use (area-wise), select multiple options if necessary:

- Small-scale crops (for subsistence and local markets)

- Other:

small-scale ranching (farm size range: 20ha - 200ha)

\section{Land system dynamics}

8) Briefly explain why this case study is interesting/relevant ${ }^{11}$, in relation to the theme(s) and land use(s) listed (points 6 and 7), and the spatio-temporal scale of analysis indicated (points 4 and 5).

\section{Relevance to themes:}

Rural-urban migration:_There is a recent rural exodus occurring across the region, and cities are growing at unprecedented rates (Parry et al., 2010). This marks an important and distinct shift in demographic trends in the region. At the end of the last century, the rural population was growing due to immigration (notably between in the 1980s into the 2000s), and tropical forests were quickly converted to crops and pasture lands for family farming. These land use change and demographic dynamics are linked to colonization and frontier development, as described in the first Tapajos case study. Since the late 2000s, however, families are beginning to migrate to cities (typically women and children first). Most often they are settling to favelas (urban slums), in search of new livelihood opportunities and better health care services and education options.

Land use/land cover (forest transitions): This rural exodus is of relevance to land use change dynamics for a number of reasons. Firstly, as family farming is abandoned, secondary forest regrowth replaces crops and pastures. This succession has implications for biodiversity and the recovery of other ecosystem services. However, as the rural space is abandoned,

\footnotetext{
${ }^{11}$ This brief justification can be social (i.e. what happens in the place or situation is of social, economic, and/or political relevance), and/or the case is well-suited for measuring particular effects or exploring possible causal relationships with a more general academic interest.
} 
family farms also become vulnerable to take-over by powerful commercialized producers and agro-businesses. Literature on deforestation and frontier trajectories in the Amazon shows that family farms are often consolidated and eventually converted to large-scale agricultural operations over time (Rudel, 1998; Browder et al., 2008). In the Tapajos Region, the soybean industry is gaining momentum near Santarém and in the south of Para State (Fig. 1) and land speculation is on the rise

\section{Relevance of spatio-temporal scale:}

The shift in demographic trends since about 2010 represents a new phase of frontier dynamics in the region. That is: a shift from family farm establishment, as documented in the previous Tapajos case study, towards a new dynamic of farm abandonment. Studying these longitudinal trends allows us to capture socio-ecological transitions and understand the influence of recent changes in the national political economy.

9) In relation with points 7 , what do you think are the most important observed trends (in the period indicated on 5) that describe this case study? Use TABLE A to list and classify important changes (or lack of change).

10) How do you explain the above listed trends observed in your case study? For this question we distinguish between 10a) drivers and 11b) events.

10a) Drivers (considering the following distinction between exogenous and endogenous drivers, and use the TABLE B to organize the relevant information):

A. Drivers exogenous to the land dynamics of your case study, i.e. independent from land use/cover and management. Further, consider the distinction between global and national drivers:

- Global drivers (or globally relevant) (e.g. Chinese demand for soy)

demand incentives to
produce

- National and Local drivers (e.g. national subsidies for fuel production)

subsidies

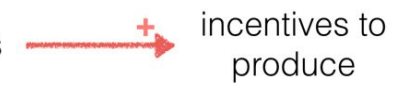

B. Drivers endogenous to the land dynamics of your case study, i.e. affected by the biophysical or socioeconomic processes that stem from land use/cover and land management. These can also be understood as:

- Feedback processes (e.g. reforestation in response to local scarcity of forest goods and services)

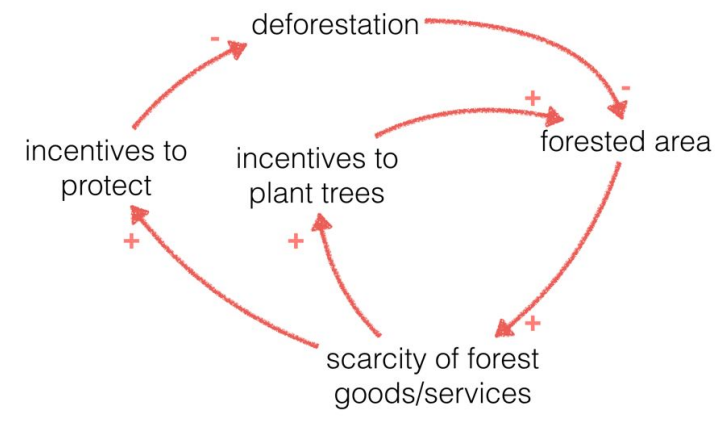


Once TABLE A and TABLE B are filled out, consider developing a simple graphical representation that synthesizes the way in which these drivers and observed trends are related in your case study. To build a simple causal-loop diagrams (as the ones sketched above), just keep in mind that arrows indicate a suggested causal influence in one direction, where a +arrow indicates that (all else being equal) change in the two linked variables goes in the same direction (positive relation), while a -arrow indicates that (all else being equal) the two linked variables change in opposite direction (negative relations). See example above.

\section{CAUSAL LOOP DIAGRAM}

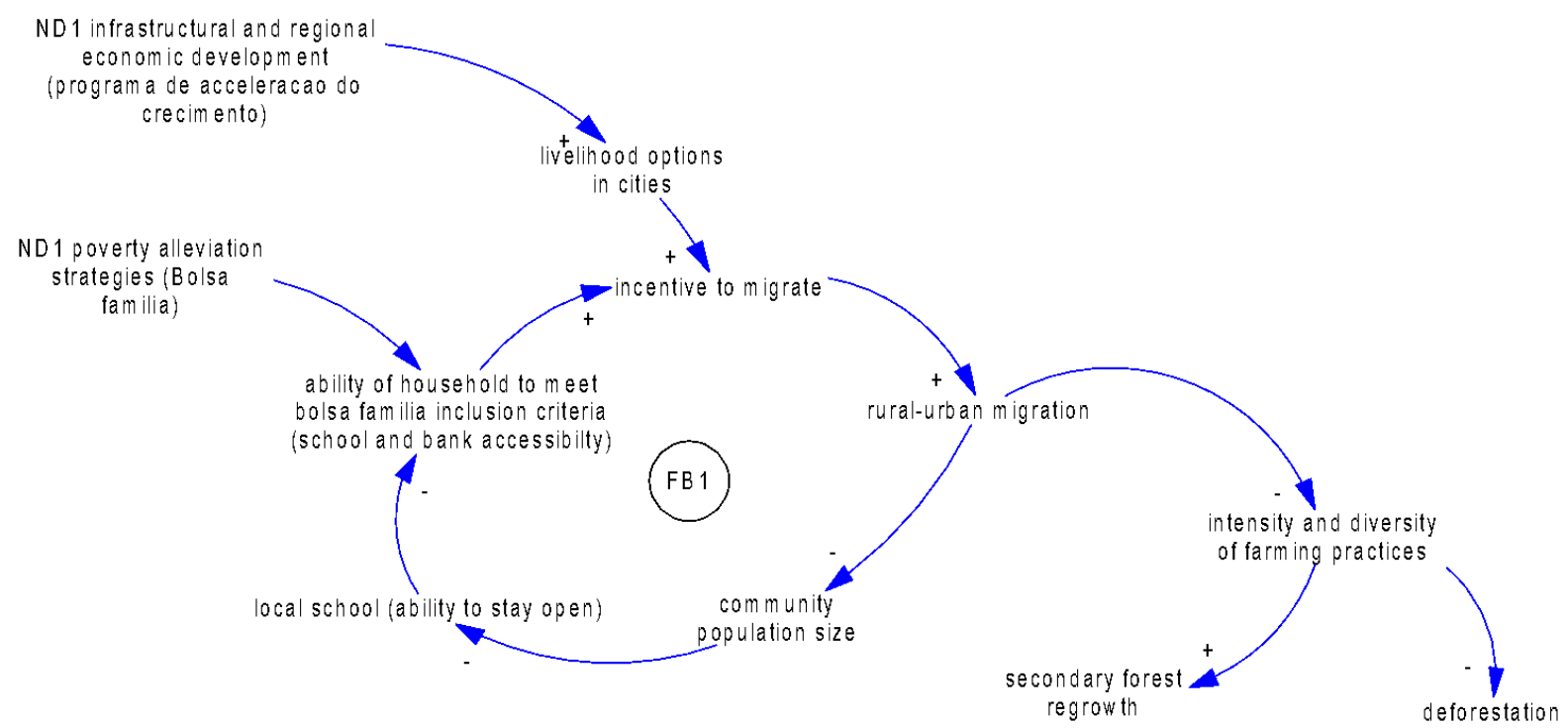

10b) Events: (This point is optional) Is there any discrete event which crucially affected the land system of your case study in the period described? (i.e. events such as a radical change in political regime, financial collapse, or environmental catastrophe). Briefly describe how it relates to the trends (9) and drivers (10a) described above.

\section{Global}

$\bullet$

-

$\bullet$

\section{National}

\section{$\bullet$}

$\bullet$

\section{Local}

- Local school closes: following slow decline in community population size (due to out migration), the local primary school closed in 2011-2012 due to lack of students. This is a tipping point, after which the remainder of families with school aged children leave the community.

$\bullet$

11) Please list all the references used to support the description of your case study in the sections 
Almeida, C. A. d., Coutinho, A. C., Esquerdo, J. C. D. M., Adami, M., Venturieri, A., Diniz, C. G., . . . Gomes, A. R. (2016). High spatial resolution land use and land cover mapping of the Brazilian Legal Amazon in 2008 using Landsat-5/TM and MODIS data. Acta Amazonica, 46(3), 291-302.

Browder, J. O., Pedlowski, M. A., Walker, R., Wynne, R. H., Summers, P. M., Abad, A., . . . Mil-Homens, J. (2008). Revisiting Theories of Frontier Expansion in the Brazilian Amazon: A Survey of the Colonist Farming Population in Rondonia's Post-Frontier, 1992-2002. World Development, 36(8), 1469-1492.

Oestreicher, J.S., Fatorelli, L., Mertens, F., Lucotte, M., Béliveau, A., Tremblay, S., Saint-Charles, J., and C. Romaña. Rural livelihood trajectories in the central Brazilian Amazon: Growing inequalities, changing practices, and emerging rural-urban relationships over nearly a decade (in press) World Development Perspectives.

Oestreicher, J. S., Farella, N., Paquet, S., Davidson, R., Lucotte, M., Mertens, F., \& Saint-Charles, J. (2014). Livelihood activities and land-use at a riparian frontier of the Brazilian Amazon: quantitative characterization and qualitative insights into the influence of knowledge, values, and beliefs. Human Ecology, 42(4), 521-540.

Parry, L., Day, B., Amaral, S., \& Peres, C. (2010). Drivers of rural exodus from Amazonian headwaters. Population \& Environment, 32(2), 137-176. doi: 10.1007/s11111-010-0127-8

PLUPH. (2013). Poor Land Use, Poor Health: primary prevention of human health through sound land-use for small-scale farmers of the humid tropics - The PLUPH Project. Final Report. International Development Research Center: Centro de desenvolvimento sustentável, Universidade de Brasília, Brazil \& Université du Québec à Montréal, Canada. Available at: http://www.pluph.uqam.ca

Rozon, C., Lucotte, M., Davidson, R., Paquet, S., Oestreicher, J. S., Mertens, F., . . Romana, C. A. (2015). Spatial and temporal evolution of family-farming land use in the Tapajós region of the Brazilian Amazon. Acta Amazonica.

Rudel, T. K. (1998). Is There a Forest Transition? Deforestation, Reforestation, and Development1. Rural Sociology, 63(4), 533-552. doi: 10.1111/j.1549-0831.1998.tb00691.x 


\title{
Land concentration and ecosystem services in Pampean agroecosystems, Argentina
}

\author{
LAND SYSTEM ARCHETYPES ELICITATION \\ CASE STUDY TEMPLATE \\ (Version 4: 2016.11.10)
}

The following color coding indicates the style of answer expected for each of the points in the template:

GREEN = Free text, paragraph style

BLUE = Free text, brief keywords or phrases

RED $=$ Choose from predefined keyword options

\section{Basic information}

1) Name of the case study

Ecosystem services provided by Pampean agroecosystems (Argentina) during 2000-2010

2) Contributors

Florencia Rositano, Cecilia Gelabert and Diego Chifarelli

Case study expert(s) (this could be either the same contributors mentioned above, or 1-3 key authors of the key literature used by the contributors to fill out this template) ${ }^{12}$

- Gras C. and Hernández V. 2013. El agro como negocio: producción, sociedad y territorios en la globalización. Ed. Biblos. 1. Ed. Bs. As.

- $\quad$ Sartelli E.; Harari F.; Kabat M.; Kornblihtt J.; Baudino V.; Dachevsky, F. Sanz Cerbino, G. 2008. Patrones en la Ruta. El conflicto agrario y los enfrentamientos en el seno de la burguesía, marzo-julio de 2008. Ed.CEICS-Ediciones ryr. Bs. As.

- Rositano F. and Ferraro D.O. 2014. Ecosystem services provided by agroecosystems: A qualitative and quantitative assessment of this relationship in the Pampa region (Argentina). Environmental Management 53: 606-619.

- $\quad$ Carreño L. and Viglizzo E. 2011. Provisión de servicios ecológicos y gestión de los ambientes rurales en Argentina. Ediciones INTA.

\section{Case study description}

3) Country (or countries, and any further jurisdictional specification, including coordinates if possible)

Pampa region, Argentina (Buenos Aires, south of Santa Fe, south of Córdoba, Entre Ríos and north of La Pampa)

4) Geographical extent (select an option to indicate the order of magnitude in $\mathrm{km}^{2}$ )

- $\quad \sim 100 \mathrm{~km}^{2}$ (landscape, local watershed, or lower administrative level)

\footnotetext{
${ }^{12}$ Mention idea of founding one case study around one main author (for consistency), and the need to get experts to check this cases' descriptions
} 
- $\quad 1.000 \mathrm{~km}^{2}$ (e.g. most Natural Parks in South America)

- $\quad 10.000 \mathrm{~km}^{2}$ (particular region within a subnational region, e.g. Southern Yucatan Peninsula)

- $\quad 100.000 \mathrm{~km}^{2}$ (subnational region, e.g. La Pampa province, Argentina)

- $\sim 500.000 \mathrm{~km}^{2}$ (subcontinental region, e.g. South American Pampas)

\section{5) Period covered}

$2000-2010$

6a) Thematic focus of study (i.e. all of these themes are connected, but what was the main explicit focus of this research):

- Land use/cover change

- Ecosystem services provision

- Biodiversity change

- Agricultural practices (mainly agronomic aspects)

- Rural economic changes

- Other:

6b) Briefly, and in relation with the thematic focus/foci indicated in $6 a$, please state what is the main phenomenon your case study addressed (e.g. agricultural intensification; habitat loss; changing livelihood)

Processes such as the introduction of different management practices or genetically modified crops, and the increase in inputs used during crop production have caused changes in Pampean agroecosystems (Pengue 2001; Satorre 2005). Moreover, socio-economic changes (e.g. new ways of agribusiness management, changes in agricultural structure) have also modified these agroecosystems. These phenomena are a threat to agroecosystems sustainability; specifically, to ecosystem services provision.

7) Dominant land use (area-wise), select multiple options if necessary:

- Small-scale crops (often, but not always for subsistence or local markets)

- Large-scale crops (commercial, beyond local markets)

- Extensive livestock (rangelands)

- Intensive livestock (feedlots)

- Forestry (managed forests or tree plantations)

- Extensive area mining

- (Semi)Wild ecosystems (conservation and/or tourism)

- Dense settlement

- Other: 


\section{Land system dynamics}

8) Briefly explain why this case study is interesting/relevant ${ }^{13}$, in relation to the theme(s) and land use(s) listed (points 6 and 7), and the spatio-temporal scale of analysis indicated (points 4 and 5).

The magnitude of the transformations involved in the agricultural process has caused a threat to Pampean agroecosystems sustainability (Casas 2003, Manuel-Navarrete et al. 2005). Previous exercises have been carried out to diagnose sustainability, using ecological (e.g. Ghersa et al. 2000, Viglizzo et al. 2002, Ferraro 2005) and socio-economical indicators (e.g. Manuel Navarrete et al. 2005). However, there is few work linking these three spheres for analysing agroecosystems sustainability (i.e. environmental, social and economic). A valuable complement to these previous studies is the inclusion of ecosystem services provision to assess the sustainability of the Pampa Region.

The Pampa Region is considered a great provider of those ecosystem services that have market value, such as food, fiber and raw material (Carreño and Viglizzo 2007). In this region, changes in the supply of ecosystem services during 1956-2005 are almost imperceptible due to the low ecological value (related to their capacity to provide a large variety of services (Costanza et al. 1997) of their lands (Carreño and Viglizzo 2011).

Based on this background, it is essential to have a framework for analysing those ecosystem services provided by Pampean agroecosystems, including explicitly the variability in agricultural management, environmental conditions, and socio-economic variations.

9) In relation with points 7, what do you think are the most important observed trends (in the period indicated on 5) that describe this case study? Use TABLE A to list and classify important changes (or lack of change).

10) How do you explain the above listed trends observed in your case study? For this question we distinguish between 10a) drivers and 11b) events.

10a) Drivers (considering the following distinction between exogenous and endogenous drivers, and use the TABLE B to organize the relevant information):

A. Drivers exogenous to the land dynamics of your case study, i.e. independent from land use/cover and management. Further, consider the distinction between global and national drivers:

- Global drivers (or globally relevant) (e.g. Chinese demand for soy)

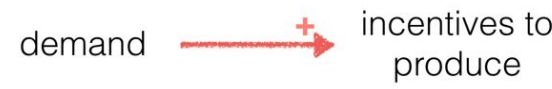

- National and Local drivers (e.g. national subsidies for fuel production)

subsidies

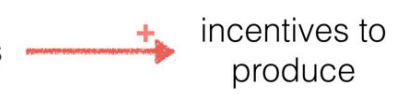

B. Drivers endogenous to the land dynamics of your case study, i.e. affected by the biophysical or socioeconomic processes that stem from land use/cover and land management. These can

\footnotetext{
${ }^{13}$ This brief justification can be social (i.e. what happens in the place or situation is of social, economic, and/or political relevance), and/or the case is well-suited for measuring particular effects or exploring possible causal relationships with a more general academic interest.
} 
also be understood as:

- $\quad$ Feedback processes (e.g. reforestation in response to local scarcity of forest goods and services)

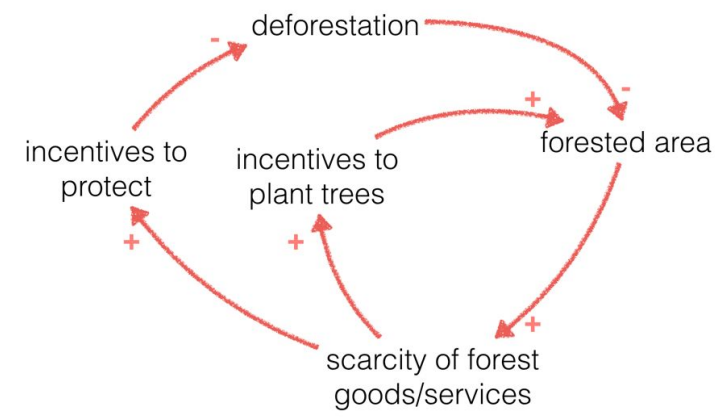

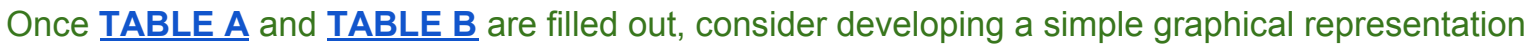
that synthesizes the way in which these drivers and observed trends are related in your case study. To build a simple causal-loop diagrams (as the ones sketched above), just keep in mind that arrows indicate a suggested causal influence in one direction, where a +arrow indicates that (all else being equal) change in the two linked variables goes in the same direction (positive relation), while a -arrow indicates that (all else being equal) the two linked variables change in opposite direction (negative relations). See example above.

10b) Events: (This point is optional) Is there any discrete event which crucially affected the land system of your case study in the period described? (i.e. events such as a radical change in political regime, financial collapse, or environmental catastrophe). Briefly describe how it relates to the trends (9) and drivers (10a) described above.

Global

- During 2006-2008, there was a significant increase in commodities prices (Figure 1). Some authors associate this increase with the process of "financialization of the commodities market" (Commission of the European Communities 2008, Doporto Miguez and Michelena 2011, Klimovsky 2012). This term refers to the increasing entry of new players into the commodities market (e.g. Investment Banks, Hedge Funds, Retirement Funds), through investments in financial instruments (e.g. index funds, commodities swaps, and exchange traded funds). Quantity and volume of financial operations linked to commodities have registered an exponential growth, reaching the value of these contracts to that of physical production several times. At the same time, there has been a substantial increase in the volatility of the prices of these goods. Other authors, however, associate rising prices with rising demand from China, India and other emerging countries as well as with tight monetary policy in United States, climate events, oil supply gaps, and increased biofuel production. 


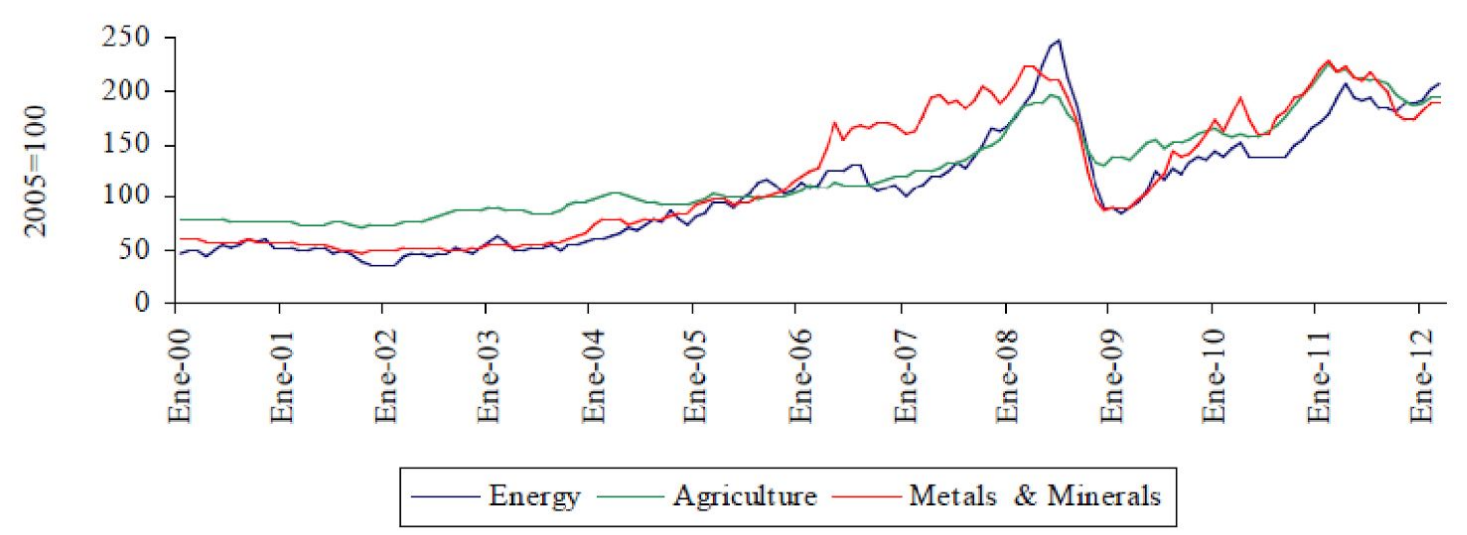

Figure 1: Evolution of commodities prices (Klimovsky 2012 based on World Bank data).

\section{National}

- Rural Lease Law ( $\left.\mathrm{N}^{\circ} 13.246\right)$ : it states that leases will have a minimum term of three $(3)$ years. It also states minimum assumptions for soil conservation practices. Nevertheless, the usual practice is the accidental contract (i.e. annual contract) discouraging cropping plans and crops rotations decision.

- In March 2008, National Ministry of Economy issues Resolution No. 125, which applies a system of mobile export tax to wheat, corn, sunflower and soybean. This resolution unleashes the agrarian strike, known as "el conflict del campo". The measure proposed by argentinian government affected farmers but did not involve other social agents within the system such as export companies, investment funds, seed and agrochemicals corporations.

\section{Local}

- Drouhgt during 2008/2009 growing season

- Appearance of socio-environmental movements that claim to fight against pollution from illegal fumigations ("Paren de Fumigar").

11) Please list all the references used to support the description of your case study in the sections above

- Aizen MA, Garibaldi LA, Dondo M (2009) Expansión de la soja y diversidad de la agricultura argentina. Ecología Austral 19: 45-54.

- Carreño L, Frank FC, Viglizzo EF (2012) Trade-offs between economic and ecosystem services in Argentina during 50 years of land-use change. Agriculture, Ecosystems \& Environment 154:68-77.

- Caride C, Piñeiro G, Paruelo JM (2012) How does agricultural management modify ecosystem services in the argentine Pampas? The effects on soil C dynamics. Agriculture, Ecosystems \& Environment 154:23-33.

- Carreño LV, Viglizzo EF (2007) Provisión de servicios ecológicos y gestión de los ambientes rurales en Argentina. Ediciones INTA. Pp. 74.

- Carreño LV, Viglizzo EF (2011) Efecto de la agricultura sobre la provisión de servicios ecosistémicos. En: Viglizzo EF, Jobbágy E (Eds.) Expansión de la frontera agropecuaria en 
Argentina y su impacto ecológico-ambiental. Ediciones INTA. Pp. 47-51.

- Commission of the European Communities (2008); Commission Staff Working Document; Task force on the role of speculation in agricultural commodities price movements; "Is there a speculative bubble in commodity markets?".

- Costanza R, d'Arge R, de Groot R, Farber S, Grasso M, Hannon B, Limburg K, Naeem S, O'Neill RV, Paruelo JM, Raskin RG, Sutton P, van den Belt M (1997) The value of the world's ecosystem services and natural capital. Nature 387:253-260.

- Doporto Miguez, Ivana and Michelena, Gabriel (2011) "La volatilidad de los precios de los commodities: el caso de los productos agrícolas".

- Ferraro DO (2005) La sustentabilidad agrícola en la Pampa Interior (Argentina): desarrollo y evaluación de indicadores de impacto ambiental del uso de pesticidas y labranzas usando lógica difusa. Tesis para obtener el título de Doctor en Ciencias Agropecuarias. Facultad de Agronomía. Universidad de Buenos Aires.

- Ghersa CM, Omacini M, Ferraro DO, Martínez-Ghersa MA, Perelman SB, Satorre EH, Soriano A (2000) Estimación de indicadores de sustentabilidad de los sistemas mixtos de producción en la Pampa Interior. Revista Argentina de Producción Animal 20:49-66.

- Giarraca N., Teubal, M and Palmisano, T. (2008). Paro agrario: crónica de un conflicto alargado Realidad económica 237.

- Gras C. and Hernández V. (2013). El agro como negocio: producción, sociedad y territorios en la globalización. Ed. Biblos. 1. Ed. Bs. As

- Klimowsky, Yael (2012). Análisis de los principales determinantes macroeconómicos de los precios de los commodities. Escuela de Negocio. Universidad Torcuato Di Tella

- Manuel-Navarrete D, Gallopin G, Blanco M, Díaz-Zorita M, Ferraro DO, Herzer H, Laterra P, Morello J, Murmis MR, Pengue W, Piñeiro M, Podestá G, Satorre EH, Torrent M, Torres F, Viglizzo E, Caputo MG, Celis A (2005) Análisis sistémico de la agriculturización en la pampa húmeda argentina y sus consecuencias en regiones extrapampeanas: sostenibilidad, brechas de conocimiento e integración de políticas. CEPAL. Serie Medio Ambiente y Desarrollo $N^{\circ} 118$. Santiago de Chile, Chile. Pp. 65.

- MEA (2005) Millenium Ecosystem Assessment. Ecosystems and human well-being. Washington, DC.

- Metzger MJ, Rounsevell MDA, Acosta-Michlik L, Leemans R, Schroter D (2006) The vulnerability of ecosystem services to land use change. Agriculture, Ecosystems \& Environment 114:69-85.

- Paruelo JM, Guerschman JP, Verón SR (2006) Expansión agrícola y cambios en el uso del suelo. Ciencia Hoy 15(87):14-23.

- Pengue WA (2005) Agricultura industrial y transnacionalización en América Latina. ¿La transgénesis de un continente? Red de Formación Ambiental. Serie Textos Básicos para la Formación Ambiental No 9. Programa de las Naciones Unidas para el Medio Ambiente, PNUMA. México.

- Pengue WA (2008) Modelo agroexportador, monoproducción y deuda ecológica. Aportes para el Estado y la Administración Gubernamental. Año 13 - Número 24: 50-83, Buenos Aires, ISSN 0328-5855

- Rositano F, Ferraro DO (2014) Ecosystem services provided by agroecosystems: A qualitative and quantitative assessment of this relationship in the Pampa region, Argentina. Environmental Management 53(3):606-619.

- Sartelli.E.; Harari F.; Kabat M.; Kornblihtt J.; Baudino V.; Dachevsky, F. Sanz Cerbino, G. (2008). Patrones en la Ruta. El conflicto agrario y los enfrentamientos en el seno de la burguesía, marzo-julio de 2008. Ed.CEICS-Ediciones ryr. Bs. As.

- Satorre EH (2005) Cambios tecnológicos en la agricultura argentina actual. Ciencia Hoy 15:24-31.

- Teubal, M. (2008). Soja y agronegocios en la Argentina: la crisis del modelo. Revista Lavboratorio, $\mathrm{N}^{\circ}$ 22, CEyDs, Buenos Aires. 
- Viglizzo EF, Frank FC (2006) Land use options for Del Plata basin in South America: Tradeoffs analysis based on ecosystem service provision. Ecological Economics 57:140-151.

- Viglizzo EF, Pordomingo AJ, Castro MG, Lértora FA (2002) La sustentabilidad ambiental de la agricultura pampeana: ¿oportunidad o pesadilla? Ciencia Hoy 12:38-51. 


\title{
Soybean agribusiness expansion in the Litoral region, Uruguay
}

\author{
LAND SYSTEM ARCHETYPES ELICITATION \\ CASE STUDY TEMPLATE
}

(Version 3: 2016.09.20)

The following color coding indicates the style of answer expected for each of the points in the template:

GREEN $=$ Free text, paragraph style

BLUE $=$ Free text, brief keywords or phrases

RED $=$ Choose from predefined keyword options

\section{Basic information}

1) Name of the case study

From land-owning cattle ranchers using sharecroppers to boost the pastures, to transnational agribusiness units managing integrated agrifood products

2) Contributors

Matilda Baraibar and Lisa Deutsch

\section{Case study description}

3) Country (or countries, and any further jurisdictional specification, including coordinates if possible) Uruguay, Litoral region (Soriano, Río Negro, Paysandú, Colonia)

4) Geographical extent (select an option to indicate the order of magnitude in $\mathrm{km}^{2}$ )

- $\quad \sim 100 \mathrm{~km}^{2}$ (landscape, local watershed, or lower administrative level)

- $\quad 1.000 \mathrm{~km}^{2}$ (e.g. most Natural Parks in South America)

- $\quad 10.000 \mathrm{~km}^{2}$ (particular region within a subnational region, e.g. Southern Yucatan Peninsula)

- $\quad$ 100.000 km² (subnational region, e.g. La Pampa province, Argentina)

- $\quad 500.000 \mathrm{~km}^{2}$ (subcontinental region, e.g. South American Pampas)

5) Period covered

2000-2015

6a) Thematic focus of study (i.e. all of these themes are connected, but what was the explicit focus of this research):

- Land use/cover change

- Ecosystem services provision

- Biodiversity change

- Agricultural practices (mainly agronomic aspects)

- Rural economic changes (e.g. actors, labor forms, business model)

- Other: 
6b) Briefly, and in relation with the thematic focus/foci indicated in 6a, please state what is the main phenomenon your case study addressed (e.g. agricultural intensification; habitat loss; changing livelihood)

Rapid change in land cover/use (cropland expansion) and land management (intensification), mainly soybeans expanding over mixed systems and pastures, between 2002 and 2015.

Shift from traditional mainly low-input, risk minimizing, integrated ranching systems (agrícola-ganadero model), in the arable land of Lítoral - to increasing agribusiness led pure crop systems, centered in a new technological package around genetically modified (GM) soybeans; led by foreign actors, responding to high international prices on soybeans and low land and leasing prices in the indebted Lítoral. Rapid increase in land (leasing) prices in the area created rapid producer concentration and disappearance of some actors (sharecroppers and family farmers). More than $67 \%$ of the area of soybean production is cultivated in productive units larger than 1000 ha in 2014/15 (DIEA 2016, 77). In 2014/2015, the soybean area in Uruguay peaked with 1.32 million hectares. Accordingly, this shift has implied land concentration and "foreignization".

The land use and land cover change came hand in hand with significant transformations in modes of organization, technology and business models. These changes involved increases in 'professionalization', technification and formalization of agricultural activities (widespread use of contracted services, technical assistance, price negotiations as opposed to traditional arrangements based on experience and family work).

The intensification in land use and the simplification of rotations (continuous crops instead of mixed systems with pastures) was soon found to create erosion of the soils (García Préchac et al. 2010, Arbeletche, Ernst, and Hoffman 2010, M., F., and Hill M Clérci C. 2010). The soybean expansion has also pushed livestock production towards intensification due to increased competition for land.

The concerns over land concentration and degradation created new regulations for adjustment/adaptation/response. More recently, regulations have been put in place to disincentivize land concentration and halt soil erosion. The most significant is the national policy from 2013 (Planes de Uso y Manejos de Suelos), which requires all producers to make land-use plans to prevent soil degradation. This requires changes in management practices with increased integration of pastures in rotation. In addition, the recent policy changes in Argentina in favor of agribusiness, have accelerated the exit of Argentine investor groups from Uruguay (Sandova 2016). However, the commercial contract-based business model and relations between social-economic actors remain intact.

7) Dominant land use (area-wise), select multiple options if no use if necessary:

- Small-scale crops (subsistence or local market oriented)

- Large-scale crops (commercial)

- Extensive livestock (rangelands)

- Intensive livestock (feedlots)

- Forestry (managed forests or tree plantations)

- Extensive area mining

- (Semi)Wild ecosystems (conservation and/or tourism) 
- Dense settlement

- Other:

\section{Land system dynamics}

8) Briefly explain why was this case study is interesting/relevant ${ }^{14}$, in relation to the theme(s) and land use(s) listed (points 6 and 7), and the spatio-temporal scales of analysis indicated (points 4 and 5).

South America has become the most important soybean producer-region in the world, and Litoral region in Uruguay is one of the most recent entrants in this complex. Soybeans have emerged from almost non-existent to become Uruguay's main export item, representing $16 \%$ of total exports in 2014 (Uruguay XXI 2015). This case study is important particularly due to the pace and scope of the biophysical and socioeconomic changes it involves. More generally, it is also a good case study to analyse how the increasing integration of rural areas in developing regions into global markets can have strong local socio-ecological implications, including various trade-offs and conflicting interests regarding what changes are desirable and/or undesirable.

For the last two decades, Uruguay has experienced a process of land use intensification (i.e. management practices) and land use changes (i.e. conversions) driven by the economic forces underlying agriculture and afforestation. This case study focuses on crop expansion. Historically, the main agricultural activity in Uruguay throughout the $19^{\text {th }}$ and $20^{\text {th }}$ centuries has been export-oriented extensive cattle raising on natural pastures, and only minor crop production in the vicinity of towns for the domestic market (Barrán and Nahum 1984, Barrán and Nahum 1981, 103-105). Approximately one-third of Uruguay's 16 million ha of arable land has been estimated suitable for crops ( 5.5 million ha). However, the cultivated area has never exceeded 10 percent, in spite of active national policies during the $20^{\text {th }}$ century to support domestic crop production (Finch 1981, Piñeiro, Giarracca, and Cloquell 1998). Since before independence, land structure has been rather stable and characterized by a high degree of concentration. The big ranchers, controlling the majority of the land, were reluctant to practice crop farming (Barrán and Nahum 1984). Crop yields per hectare throughout the $20^{\text {th }}$ century were lower than in Argentina and than world average (Finch 1981, 88-90). The low yields have been explained by lack of scale and low use of "modern technology", i.e., improved seeds, fertilizers and pesticides and other "Green Revolution" technologies (Shardul Agrawala 2004). In addition, conventional tilling (plough-based farming systems) resulted in erosion and general degradation of organic matter and a decline in productivity.

As a response to the problem of erosion, as well as to overgrazing livestock on rangelands, different types of crop-pasture rotation systems were developed (Díaz Rossello 2001). Almost all crop production in Uruguay became integrated in mixed systems with livestock in the 1960s and 70s, referred to as the model of agrícola-ganadera (AG). The AG system most commonly included schemes of 3-4 years of cereals and oil seeds, followed by 3-4 years of sown pastures (grasses and legumes) for beef production, and then another period of crops, and so on. The period culminated with a winter crop (often wheat), co-associated with pastures (fescue, white clover and lotus). The area along the Uruguay river called the Litoral became the crop area par excellence, due to its fertile soils and good communications (infrastructure, processing plants). Extensive cultivations in other areas of the country almost

\footnotetext{
${ }^{14}$ This brief justification can be social (i.e. what happens in the place or situation is of social, economic, and/or political relevance), and/or the case is well-suited for measuring particular effects or exploring possible causal relationships with a more general academic interest.
} 
disappeared, since total area in crops retracted as yields improved with the AG system and public subsidies for cultivations were removed (Finch 1981, 63-64; 118-122). The dominant management model became mixed crop production in rotation with pastures (Achkar et al. 2011, Arbeletche and Carballo 2009). While some crop producers owned their land, most cultivations were managed by sharecroppers, while the big landowners were typically exclusively ranchers. The crop producers mainly concentrated on wheat, sunflowers, and barley. During the 1970s a few producers tried conventional (non-GM crops) soybean cultivation, which was promoted by national researchers because of its nitrogen-fixing qualities and by a bilateral trade agreement with Taiwan providing higher than market prices, but interest among producers stayed low and yields per hectare were also rather low.

According to USDA statistics, soybean harvest was only 12,000 tons for the 2000/2001 season (Sandova 2016). In 2002, an economic crisis in Argentina led actors with capital and a new technology package for no-till soybean production to enter an equally crisis-stricken Uruguay, in which many farmers were heavily indebted (Arbeletche and Carballo 2009, Arbeletche and Gutiérrez 2010). These actors were already important crop producers in Argentina and started to practice continuous cultivation of herbicide tolerant $(\mathrm{HT})$ soybeans and/or with other crops, using no-tillage farming techniques. All these economic factors combined to overwhelm previous Uruguayan cultural resistance to changing farming systems and resulted in the widespread adoption of the high-tech agricultural package of GM soybeans (based on a Glyphosate-tolerant genotype). Within a few years, large-scale expansion of crop cultivations affected the livestock sector as the most productive grazing areas were taken for continuous crop production (Piñeiro 2011). According to the National Agrarian Statistical Division (DIEA) of the Department of Livestock, Agriculture and Flsheries (MGAP), the 2014/2015 harvest of soybeans in Uruguay covered an area of 1.334 million hectares, with a harvest of 3.109 million tons, representing an average yield of $2.331 \mathrm{~kg} / \mathrm{ha}$ (DIEA 2016, 71). The expansion has largely come at the expense of grasslands and mixed systems (Tommasino 2010).

9) In relation with points 7, what do you think are the most important observed trends (in the period indicated on 5) that describe this case study? Use TABLE A to list and classify important changes (or lack of change).

\section{See information here: TABLE A: Trends (sheet 1)}

10) How do you explain the above listed trends observed in your case study? For this question we distinguish between 10a) drivers and 11b) events.

10a) Drivers (considering the following distinction between exogenous and endogenous drivers, and use the TABLE B) to organize the relevant information):

A. Drivers exogenous to the land dynamics of your case study, i.e. independent from land use/cover and management. Further, consider the distinction between global and national drivers:

- Global drivers (or globally relevant) (e.g. Chinese demand for soy)

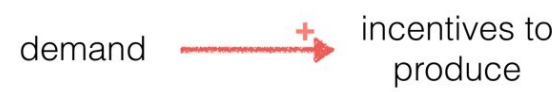


- National and Local drivers (e.g. national subsidies for fuel production)

subsidies incentives to produce

B. Drivers endogenous to the land dynamics of your case study, i.e. affected by the biophysical or socioeconomic processes that stem from land use/cover and land management. These can also be understood as:

- Feedback processes (e.g. reforestation in response to local scarcity of forest goods and services)

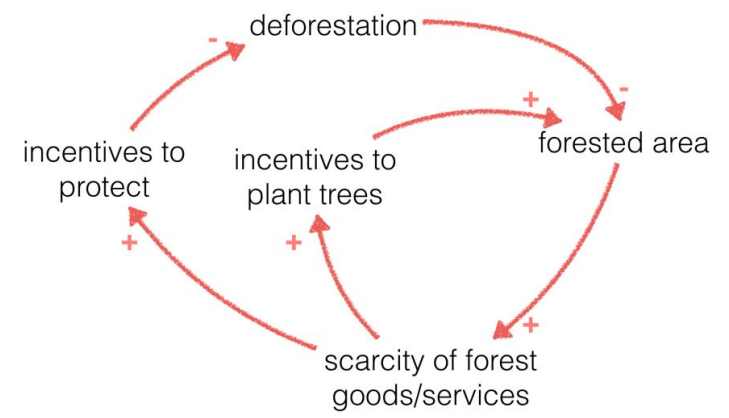

See information here: TABLE B: Drivers (sheet 2)

Once TABLE A and TABLE B are filled out, consider developing a simple graphical representation that synthesizes the way in which these drivers and observed trends are related in your case study. To build a simple causal-loop diagrams (as the ones sketched above), just keep in mind that arrows indicate a suggested causal influence in one direction, where a +arrow indicates that (all else being equal) change in the two linked variables goes in the same direction (positive relation), while a -arrow indicates that (all else being equal) the two linked variables change in opposite direction (negative relations). See example above.

10b) Events: (This point is optional) Is there any discrete event which crucially affected the land system of your case study in the period described? (i.e. events such as a radical change in political regime, financial collapse, or environmental catastrophe). Briefly describe how it relates to the trends (9) and drivers (10a) described above.

\section{Global}

- $\quad$ Chinese pre-accession into the WTO (1990s): China has pursued a policy of national food security based on self-sufficiency for quite some time, but in the 1990s i slightly relaxed the level of grain sufficiency in preparation for China's entry into the World Trade Organization (WTO) in 2001 (Hairong, Yiyuan, and Bun 2016). The lowest degree of self-sufficiency is allowed for soybeans and, consequently, China has become the world's biggest soybean importer (Zhang and Liu 2014). China accounts for a large share of the markets for soybeans, and soybean imports to China are projected to account for more than $65 \%$ of world imports by 2025 (OECD/FAO 2016a). China encompasses the majority of Uruguay's export market share, with over 80 percent (Sandova 2016).

- Herbicide tolerant soybeans (1996): The herbicide tolerant soybean (GTS 40-3-2), often referred to as a RR (Roundup Ready) soybean, was patented by Monsanto in 1996. The RR soybean is genetically modified to allow the use of glyphosate as a total weed killer and no-tillage farming. Almost all soybean production in Uruguay is GM, and all authorized 'events' are designed to be herbicide tolerant. The technological package has allowed 
producers to reduce costs (reduced fueling costs and glyphosate is cheap), promote intensification (no-tillage and short cycle seed varieties allow for double-cropping) and improved yields in less suitable soils (Barbazán et al. 2011, Souto and Ferenczi 2010, Souto 2013). In the context of current world prices for soybeans, this technological package has resulted in a gross margin for soybean production that is higher than any other agrarian activity (at least under normal climate conditions, for cattle raising is much more resilient to drought) (USDA 2011, DIEA 2011).

- Policy changes in Argentina (2000s). In January 2002, Argentina broke the fixed peg of one-to-one parity between the Argentinean peso and the US dollar, resulting in a 75 percent devaluation of the peso. Argentinean farmers were also heavily indebted, but many benefitted from the devaluation as loans taken in dollars were able to be repaid in the now much less valued peso (Baraibar 2014, 231). The regime of high export taxes on soybeans and byproducts (but lesser taxes on soybean meal and oil), along with the imposition of export permits, under the Kirschner and Fernandez governments, discouraged soybean production and led Argentine capital and production firms to move to Uruguay. In addition, the biotech company Monsanto had conflicts with the Argentinean government and withdrew in 2004 from the soybean market because of lack of enforcement of intellectual property rights by the government (Baraibar 2014, 210-211). The change of government in December 2015 (Macri), however, has implied a positive policy development for the grain and soybean sector in Argentina. This is discouraging soybean production in Uruguay (together with the weakening of soybean prices). This has not affected the Litoral as much as the historical livestock areas (the departments of Salto, Paysandú, Florida, and Durazno) which are farther from ports and have less apt soils for crops (Sandova 2016).

\section{National}

- Early authorization of genetically modified soybeans (1996): The Division for Agricultural Protection Services (DGSA) of the Department of Livestock and Agriculture and fisheries (MGAP) authorized HT soybeans for production and commercialization through a resolution in 1996 (Bianco-Bozzo et al. 2010, Borsani et al. 2010). All of Uruguay's soybean varieties are derived from biotechnology (Bosso de Brum 2010). That would not happen again until 2009, when a Monsanto event was authorized for seed exports, while events for production, consumption and commercialization from both Monsanto and Bayer CropScience were authorized in 2012, as well as a new soybean event from BASF in 2014 (INASE 2016).

- Legislation on land use and management plans (2013): The Uruguayan state implemented legislation (Decreto 405/008 y Ley 18.564 - Suelos y Aguas) requiring producers to submit plans for land use and management for every landholding above 100ha Developed by an agronomy expert accredited with the MGAP, these management plans have important implications for croplands as they establish the appropriate rotation schemes to limit soil degradation (Paolino et al 2014, García 2015).

11) Please list all the references used to support the description of your case study in the sections above

Arbeletche, P., and Gutiérrez, G. 2010. "Crecimiento de la agricultura en Uruguay: exclusión social o integración económica en redes." PAMPA, Revista Interuniversitaria de Estudios Territoriales no. 6 .

Arbeletche, P., and Carballo, C. 2009. "La expansión agrícola en Uruguay: Algunas de sus principales consecuencias." Revista de Desarrollo Rural y Cooperativismo Agrario no. 12:7-20. 
Arbeletche, P., Coppola, M., and Paladino, C.. 2012. "Análisis del agro-negocio como forma de gestión empresarial en América del Sur: el caso uruguayo." Agrociencia Uruguay no.

16:110-119.

Baraibar, M. 2014. Green Deserts or New Opportunities?: Competing and complementary views on the soybean expansion in Uruguay, 2002-2013. Monograph, Economic History, Stockholm University, Stockholm.

Barbazán, M., Bautes, C., Beux, L., Bordoli, M., Cano, J., Ernst, O., García, A., García, F., and Quincke, A. 2011. "Fertilización potásica en cultivos de secano sin laboreo en Uruguay: rendimiento según análisis de suelos." Agrociencia Uruguay no. 15:93-99.

Barrios, J., Gandelman, N., and Michelin, G. 2010. Analysis of Several Productive Development Policies in Uruguay. In IDB working paper series, edited by IDB. Montevideo: Universidad ORT Uruguay.

Berterreche, A. 2009-02-19. Vice-Minister of MGAP 2008-2009, . Interview made in Montevideo, 2009-02-19.

Bianco-Bozzo, M., Chiappe, M., Hernández, C., and Carámbula M. 2010. "Agrobiotecnologías en Uruguay: Posicionamiento de actores en torno a un debate incierto." Agricultura, sociedad y desarrollo no. 7 (3):18.

Borsani, O., Castiglioni, E., Chiappe, M., Ferenczi, A., Carcía, F., Pritsch, C., and Speranza, P. 2010. "Biotecnología moderna, cultivares transgénicos y proceso de adopción en Uruguay." In Intensificación Agrícola: oportunidades y amenazas para un país productivo y natural, edited by García Préchac, Ernst, Arbeletche, Perez Bidegain,Pritsch, Ferenczi and Rivas, 29-67. Montevideo: Udelar - CSIC.

Bosso de Brum, A. 2010. Persistencia del glifosato y efecto de sucesivas aplicaciones de sucesivas aplicaciones en el cultivo de soja en agricultura continua en siembra directa sobre parámetros biológicos del suelo, Environmental Science, Universidad de la República (UdelaR), Montevido.

Bruno, A. 2007. Plaguicidas usados en el cultivo de soja. Evolución de su uso y estimación de su impacto ambiental,.

Carriquiry, F. 2015. "El papel del agro en el desarrollo económico nacional." In El desarrollo agropecuario y agroindustrial de Uruguay: Reflexiones en el 50 aniversario de la Oficina de Programación y Política Agropecuaria (OPYPA- MGAP), edited by Unidad de Comunicación Organizacional y Difusión MGAP and Diego OPYPA-MGAP Campoy, 26-35. Montevideo: OPYPA-MGAP.

DIEA. 2011. Anuario Estadístico Agropecuario 2011. Edited by DIEA - MGAP, Anuario Estadístico Agropecuario. Montevideo: División de Estadísticas Agropecuarias,.

DIEA. 2014. Anuario Estadístico Agropecuario 2013. edited by Agricultura y Pesca (MGAP) Ministerio de Ganadería, Dirección de Investigaciones Económicas Agropecuarias (DIEA). Montevideo: DIEA-MGAP.

DIEA. 2016. Anuario DIEA 2015. Edited by Mgap. Montevideo: MGAP.

Durán, Verónica , and Lucía Salgado. 2013. "Avances en el régimen de promoción de inversiones (COMAP)." In Anuario Opypa 2013, edited by MGAP-OPYPA. Montevideo: Agropecuaria Hemisferio Sur.

Errea, E., Peyrou, J., Secco, J., and Souto, G. 2011a. Transformaciones en el agro uruguayo Nuevas instituciones y modelos de organización empresarial. Edited by Dámaso Antonio Larrañaga Universidad Católica del Uruguay, Facutad de Ciencias Empresariales, Programa de Agronegocios. Universidad Católica. Montevideo: Facutad de Ciencias Empresariales, Programa de Agronegocios.

García, F. 2015. Agricultura en el Cono Sur ¿Qué se conoce, qué falta por conocer?. Quito: UCE. 13 p. - http://www.dspace.uce.edu.ec/handle/25000/5153

Garín, D. 2010-12-20. Vice-Minister of MGAP 2009-2012. Interview made in Montevideo, 2010-12-20. 
GEF \& FAO. 2015. Project: Strengthening capacities for the sound management of pesticides including POPs (MSP) in Uruguay. Food and Agriculture Organization, Global Environment Facility.

Gonsalves, G. 2010. La problemática de la tierra en Uruguay. Un recurso natural estratégico que merece de políticas de estado nacional y regional. Edited by sociales y cultureles, Centro artiguista de los derechos económicos. Montevideo: CADESYC.

Hairong, Yan, Chen Yiyuan, and Ku Hok Bun. 2016. "China's soybean crisis: the logic of modernization and its discontents." The Journal of Peasant Studies no. 43 (2):373-395. doi: 10.1080/03066150.2015.1132205.

INASE. 2016. Descripción de Cultivares de Soja. In Serie de divulgación Técnica, edited by INASE. Montevideo: Instituto Nacional de Semillas.

MGAP. 2014. Censo General Agropecuario 2011 - Resultados definitivos. edited by MGAP. Montevideo: Estadísticas Agropecuarias (DIEA).

OECD/FAO. 2016a. OECD-FAO Agricultural Outlook 2016-2025,. Paris: Economic and Social Development Department, .

OECD/FAO. 2016b. "Oilseeds and oilseed products." In OECD-FAO Agricultural Outlook 2016-2025, edited by OECD / FAO, 13. Paris: OECD Publishing.

Oyhantçabal, G., and Narbondo, I. 2011. Radiografía del agronegocio sojero - Descripción de los principales actores y los impactos socio-económicos en Uruguay. Datos actualizados a 2010. Second edition (first 2008) ed. Montevideo: Redes-AT.

Paolino, C. Pittaluga, L. Mondelli, M (2014) Cambios en la dinámica agropecuaria y agroindustrial del Uruguay y las políticas públicas. Serie: Estudios y Perspectivas - (Montevideo), No. 15. 98 p. LC/MVD/L.45 http://repositorio.cepal.org/handle/11362/36780

Paulino, C. 2015. "La política pública y el apoyo al sector agropecuario." In El desarrollo agropecuario y agroindustrial de Uruguay: Reflexiones en el 50 aniversario de la Oficina de Programación y Política Agropecuaria (OPYPA- MGAP), edited by MGAP Unidad de Comunicación Organizacional y Difusión and Diego OPYPA-MGAP Campoy, 37-45. Montevideo: OPYPA-MGAP.

Piñeiro, D. 2011a. "Dinámicas en el mercado de la tierra en América Latina: el caso de Uruguay." In Procesos de concentración y extranjerización de tierras en América Latina y el Caribe, edited by FAO. Santiago de Chile: Oficina Regional de la FAO.

Piñeiro, D. 2011b. "El caso de Uruguay." In Procesos de concentración y extranjerización de tierras en América Latina y el Caribe, edited by FAO. Santiago de Chile: Oficina Regional de la FAO.

Piñeiro, D. 2015. "Los Cambios en la Sociedad Rural del Uruguay a comienzos del Siglo XXI." Novos Rumos Sociológicos no. 3 (4):292-307.

Ríos, Belgeri, Cabrera, Della Valle, Ferrari, Aristegui, Frondoy, and Gómez. 2013. "Prevención de la resistencia de Raigrass anual (Lolium multiflorum LAM) y Yerba Carnicera (Conyza bonariensis L.) en Uruguay." In Viabilidad del glifosato en sistemas productivos sustentables., edited by Amalia Ríos, 83-97. Montevideo: INIA - Instituto Nacional de Investigación Agropecuaria,.

Sandova, L. 2016. Oilseeds and Products Annual: Uruguay. In GAIN Report, edited by USDA. Souto, G. 2013. "Oleaginosos y derivados: situación y perspectivas." In Anuario 2013, Opypa: Cadenas productivas; temas de política; Proyectos, estudios y documentos, edited by OPYPAMGAP, 17. Montevideo: Editorial Agropecuaria Hemisferio Sur.

Souto, G., and Ferenczi, A. 2010. "Organismos genéticamente modificados: avances en la instrumentación del nuevo marco regulatorio." In Anuario Opypa 2010, edited by MGAP-OPYPA. Montevideo Agropecuaria Hemisferio Sur.

Tommasino, H. 2010. "15 años de cambios en el agro: impacto en la ganadería vacuna." In Anuario Opypa 2010, edited by Agropecuaria del Hemisferio Sur. Montevideo: MGAP-OPYPA. 
Traders of Dreyfus. 2008-02-19. Louis Dreyfus Commodities, LDC. Interview made in Young, Río Negro, Uruguay.

Turban, I. 2013. El Tejar: Interview with Ismael Turban. SoundCloud: Blasina y Asociados: Agronegocios y comunicación.

USDA, Foreign Agricultural Service -. 2011. Oilseeds: World market and Trade, May 2011. In Circular Series: United States Department of Agriculture.

Uruguay XXI. 2013a. Oleaginosos - Junio-2013. In Oleaginosos, edited by Departamento de Inteligencia Competitiva. Montevideo: Uruguay XXI: Promoción de inversiones y exportación.

Uruguay XXI. 2013b. Uruguay: a place to invest, work and live. Instituto de Promoción de Inversiones y Exportaciones. Montevideo.

Uruguay XXI. 2015. Informe de comercio exterior - exportaciones e importaciones de Uruguay. In Informe de comercio exterior. Montevideo: URUGUAY XXI Instituto de Promoción de Inversiones y Exportaciones.

Zhang, Q., and Lifeng L. 2014. "Perspective on the Trend of Soybean Production and Trade in China." In Proceedings of Selected Articles of 2013 World Agricultural Outlook Conference, edited by Shiwei Xu, 19-28. Springer Berlin Heidelberg. 


\title{
Expansion of small-scale agriculture and ranching, Pará, Brazil
}

\author{
LAND SYSTEM ARCHETYPES ELICITATION \\ CASE STUDY TEMPLATE \\ (Version 4: 2016.11.10)
}

The following color coding indicates the style of answer expected for each of the points in the template:

GREEN = Free text, paragraph style

BLUE = Free text, brief keywords or phrases

RED $=$ Choose from predefined keyword options

\section{Basic information}

1) Name of the case study

Expansion of small-scale agriculture and ranching in area of influence of the BR-163/BR-230

(Tapajós River region, Brazilian Amazon) following gold boom-bust cycle

2) Contributors

J.S. Oestreicher, PhD.

Case study expert(s) (this could be either the same contributors mentioned above, or 1-3 key authors of the key literature used by the contributors to fill out this template) ${ }^{15}$

Rozon et al., 2014; Oestreicher et al., 2014; Oestreicher et al., in press

\section{Case study description}

3) Country (or countries, and any further jurisdictional specification, including coordinates if possible)

Area of influence: Santarém-Cuiabá and Transamazon highways (BR-163 \& BR-230).

Municipalities: Aveiro, Itaituba, and Ruropolis.

Tapajós River Region, State of Pará, Brazil.

Coordinates for the city of Itaituba: $04^{\circ} 28^{\prime} \mathrm{S}, 55^{\circ} 99^{\prime} \mathrm{W}$

*See Figure 1, Annex

4) Geographical extent (select an option to indicate the order of magnitude in $\mathrm{km}^{2}$ )

- $\quad \sim 100 \mathrm{~km}^{2}$ (landscape, local watershed, or lower administrative level)

5) Period covered

$1990-2008$

6a) Thematic focus of study (i.e. all of these themes are connected, but what was the main explicit

${ }^{15}$ Mention idea of founding one case study around one main author (for consistency), and the need to get experts to check this cases' descriptions 
focus of this research):

- Other:

Ecohealth (linkages between land use/cover change and ecosystem service provision)

6b) Briefly, and in relation with the thematic focus/foci indicated in 6a, please state what is the main phenomenon your case study addressed (e.g. agricultural intensification; habitat loss; changing livelihood)

This case study draws on work conducted during PLUPH project (Poor Land Use, Poor Health), an interdisciplinary, international, participatory research and intervention project that focused on the linkages between land use/cover change and ecosystem service provision. More specifically, we examined deforestation, land use practices (i.e., slash and burn agriculture), and two emerging public health risks (Chagas disease exposure and methylmercury intoxication) in the Tapajós River region. The research component included studies on: livelihoods and natural resource management, land use and dispersal of Chagas vectors, land use and movement of mercury, and epidemiological surveys. The intervention component focused exclusively on the development of agroforestry systems using participatory methods. See: http://www.pluph.uqam.ca

7) Dominant land use (area-wise), select multiple options if necessary:

- Small-scale crops (for subsistence and local markets)

- Other:

small-scale ranching (farm size range: $20 \mathrm{ha}$ - 200ha)

\section{Land system dynamics}

8) Briefly explain why this case study is interesting/relevant ${ }^{16}$, in relation to the theme(s) and land use(s) listed (points 6 and 7), and the spatio-temporal scale of analysis indicated (points 4 and 5).

Relevance to themes: Deforestation and land use management practices in the Amazon have implications at both for ecosystems and people at the local and the global levels:

1) Land use systems as indicators of local human health: Chagas disease is an emerging risk in the Amazon, and increasing transmission rates are demanding attention from public health officials (Valente et al., 1999; Moncayo et al., 2009). At the same time, some of the highest levels of mercury intoxication have been documented among populations in the Tapajos River region (Mergler et al., 2007). Both health concerns are linked to deforestation, slash and burn agricultural practices, and land degradation that shift ecosystem processes, including the cycling of geochemicals and disease vectors/pathogens (Patz et al., 2004; Myers and Patz, 2009; PLUPH, 2013; Davidson et al., 2012, Confalonieri et al., 2014). Public health planning could thus benefit from monitoring land use systems dynamics.

2) Land use/cover change is a social equity and environmental justice issue: Development of the Amazon has generated extreme social and economic inequalities

\footnotetext{
${ }^{16}$ This brief justification can be social (i.e. what happens in the place or situation is of social, economic, and/or political relevance), and/or the case is well-suited for measuring particular effects or exploring possible causal relationships with a more general academic interest.
} 


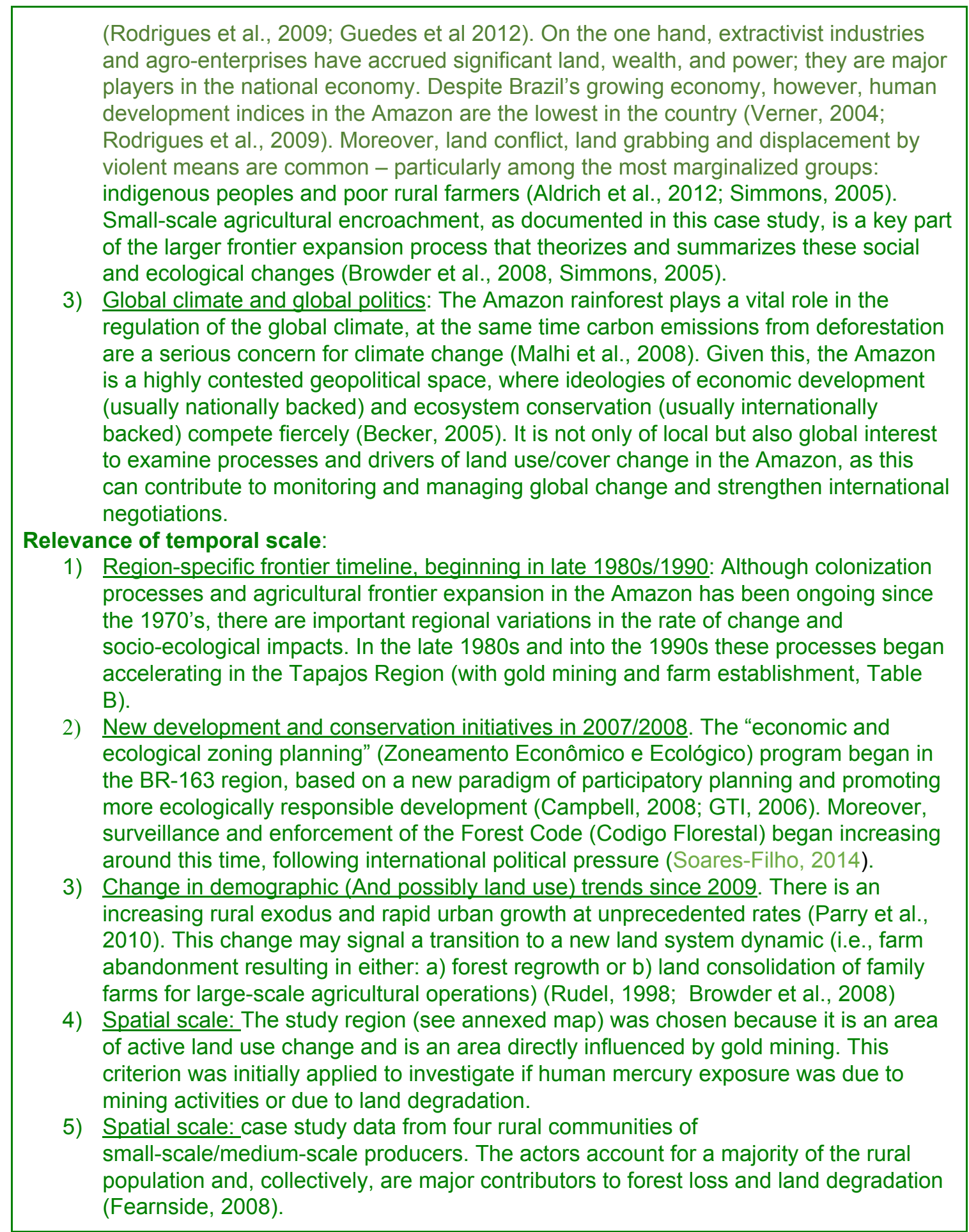

9) In relation with points 7, what do you think are the most important observed trends (in the period indicated on 5) that describe this case study? Use TABLE A to list and classify important changes (or lack of change).

10) How do you explain the above listed trends observed in your case study? For this question we distinguish between 10a) drivers and 11b) events.

10a) Drivers (considering the following distinction between exogenous and endogenous drivers, and use the TABLE B to organize the relevant information): 
A. Drivers exogenous to the land dynamics of your case study, i.e. independent from land use/cover and management. Further, consider the distinction between global and national drivers:

- Global drivers (or globally relevant) (e.g. Chinese demand for soy)

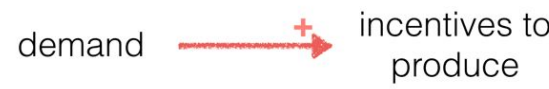

- National and Local drivers (e.g. national subsidies for fuel production)

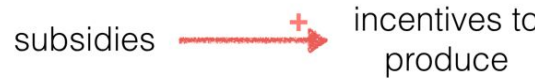

B. Drivers endogenous to the land dynamics of your case study, i.e. affected by the biophysical or socioeconomic processes that stem from land use/cover and land management. These can also be understood as:

- Feedback processes (e.g. reforestation in response to local scarcity of forest goods and services)

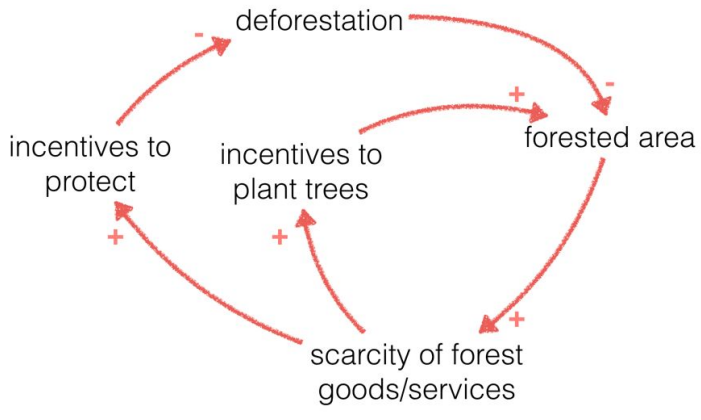

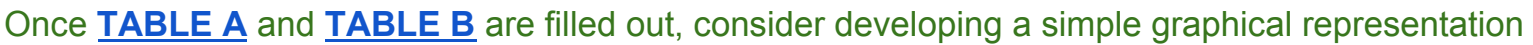
that synthesizes the way in which these drivers and observed trends are related in your case study. To build a simple causal-loop diagrams (as the ones sketched above), just keep in mind that arrows indicate a suggested causal influence in one direction, where a +arrow indicates that (all else being equal) change in the two linked variables goes in the same direction (positive relation), while a -arrow indicates that (all else being equal) the two linked variables change in opposite direction (negative relations). See example above.

\section{CAUSAL LOOP DIAGRAM}




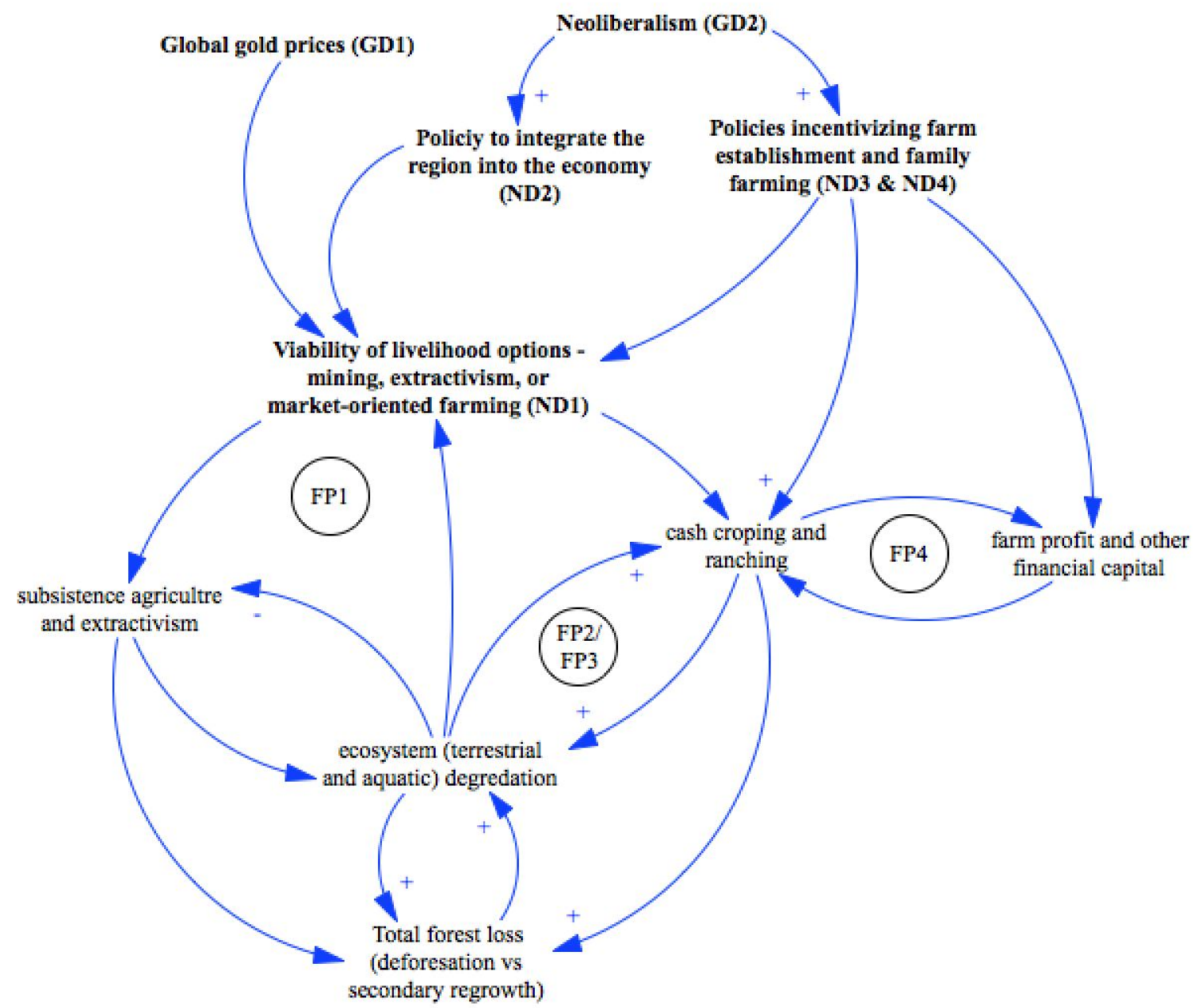

10b) Events: (This point is optional) Is there any discrete event which crucially affected the land system of your case study in the period described? (i.e. events such as a radical change in political regime, financial collapse, or environmental catastrophe). Briefly describe how it relates to the trends (9) and drivers (10a) described above.

Global

-

-

National

- In 1990 the Plano Collar (a series of economic reform plans) brought about a drop in the internal price of gold and an increase in the cost of production (independent of global market prices and demand). Mine operations closing and slowing is linked to population trends, as noted in attached Annex (Source: ZEE, 2005)

-

-

\section{Local}


11) Please list all the references used to support the description of your case study in the sections above

Aldrich, S., Walker, R., Simmons, C., Caldas, M., \& Perz, S. (2012). Contentious Land Change in the Amazon's Arc of Deforestation. Annals of the Association of American Geographers, 102(1), 103-128. doi: 10.1080/00045608.2011.620501

Becker, B. K. (2005). Geopolítica da amazônia. Estudos avançados, 19(53), 71-86.

Bezerra, O., Veríssimo, A., \& Uhl, C. (1996). The regional impacts of small-scale gold mining in Amazonia. Natural Resources Forum, 20(4), 305-317.

Browder, J. O., Pedlowski, M. A., Walker, R., Wynne, R. H., Summers, P. M., Abad, A., . . . Mil-Homens, J. (2008). Revisiting Theories of Frontier Expansion in the Brazilian Amazon: A Survey of the Colonist Farming Population in Rondonia's Post-Frontier, 1992-2002. World Development, 36(8), 1469-1492.

Campbell, J. M. (2008). Fixing Sustainability along the Unpaved Santarém-Cuiabá Highway. Paper presented at the American Anthropological Association Meeting, November 22.

Confalonieri, U. E., Margonari, C., \& Quintão, A. F. (2014). Environmental change and the dynamics of parasitic diseases in the Amazon. Acta Tropica, 129, 33-41.

Davidson, E. A., de Araújo, A. C., Artaxo, P., Balch, J. K., Brown, I. F., Bustamante, M. M., . . Longo, M. (2012). The Amazon basin in transition. Nature, 481(7381), 321-328.

Fatorelli, L. (2013). Percepçoes sobre mudanças ambientais na Amazônia Brasiliera: Caminhos para a construção de um conhecimento integrador. (PhD), Universidade de Brasilia, Brasilia, Brazil.

Fearnside, P. M. (2002). Avanca Brasil: environmental and social consequences of Brazil's planned infrastructure in Amazonia. Environmental Management, 30(6), 0735-0747.

Fearnside, P. M. (2008). The roles and movements of actors in the deforestation of Brazilian Amazonia. Ecology and Society, 13(1), 23.

GTI. (2006). Plano de Desenvolvimento Regional Sustentável para a Área de Influência da Rodovia BR-163: Grupo de Trabalho Interministerial (GTI), governo do Brasil.

Guedes, G. R., Brondízio, E. S., Barbieri, A. F., Anne, R., Penna-Firme, R., \& D’Antona, Á. O. (2012). Poverty and inequality in the rural Brazilian Amazon: a multidimensional approach. Human Ecology, 40(1), 41-57.

Kleinman, P., Pimentel, D., \& Bryant, R. B. (1995). The ecological sustainability of slash-and-burn agriculture. Agriculture, Ecosystems \& Environment, 52(2), 235-249.

Malhi, Y., Roberts, J. T., Betts, R. A., Killeen, T. J., Li, W., \& Nobre, C. A. (2008). Climate Change, Deforestation, and the Fate of the Amazon. Science, 319(5860), 169-172. doi: 10.1126/science.1146961

Mergler, D., Anderson, H. A., Chan, L. H. M., Mahaffey, K. R., Murray, M., Sakamoto, M., \& Stern, A. H. (2007). Methylmercury Exposure and Health Effects in Humans: A Worldwide Concern. AMBIO: A Journal of the Human Environment, 36(1), 3-11.

Moncayo, Á., \& Silveira, A. C. (2009). Current epidemiological trends for Chagas disease in Latin America and future challenges in epidemiology, surveillance and health policy. Memórias do Instituto Oswaldo Cruz, 104, 17-30.

Myers, S. S., \& Patz, J. A. (2009). Emerging Threats to Human Health from Global Environmental Change. Annual Review of Environment and Resources, 34(1), 223-252. doi: doi:10.1146/annurev.environ.033108.102650

Oestreicher, J.S., Fatorelli, L., Mertens, F., Lucotte, M., Béliveau, A., Tremblay, S., Saint-Charles, J., and C. Romaña. Rural livelihood trajectories in the central Brazilian Amazon: Growing inequalities, changing practices, and emerging rural-urban relationships over nearly a decade (in press) World Development Perspectives.

Oestreicher, J. S., Farella, N., Paquet, S., Davidson, R., Lucotte, M., Mertens, F., \& Saint-Charles, J. (2014). Livelihood activities and land-use at a riparian frontier of the Brazilian Amazon: quantitative characterization and qualitative insights into the influence of knowledge, values, and beliefs. Human Ecology, 42(4), 521-540. 
Pacheco, P. (2009). Agrarian reform in the Brazilian Amazon: its implications for land distribution and deforestation. World Development, 37(8), 1337-1347.

Patry, C., Davidson, R., Lucotte, M., \& Béliveau, A. (2013). Impact of forested fallows on fertility and mercury content in soils of the Tapajós River region, Brazilian Amazon. Science of the Total Environment, 458, 228-237.

Parry, L., Day, B., Amaral, S., \& Peres, C. (2010). Drivers of rural exodus from Amazonian headwaters. Population \& Environment, 32(2), 137-176. doi: 10.1007/s11111-010-0127-8

Patz, J. A., Daszak, P., Tabor, G. M., Aguirre, A. A., Pearl, M., Jon, E., . . Disease, E. (2004). Unhealthy Landscapes: Policy Recommendations on Land Use Change and Infectious Disease Emergence. Environmental Health Perspectives, 112(10), 1092-1098.

PLUPH. (2013). Poor Land Use, Poor Health: primary prevention of human health through sound land-use for small-scale farmers of the humid tropics - The PLUPH Project. Final Report. International Development Research Center: Centro de desenvolvimento sustentável, Universidade de Brasília, Brazil \& Université du Québec à Montréal, Canada. Available at: http://www.pluph.uqam.ca

Rodrigues, A. S. L., Ewers, R. M., Parry, L., Jr., C. S., Veríssimo, A., \& Balmford, A. (2009). Boom-and-Bust Development Patterns Across the Amazon Deforestation Frontier. Science, 324(1435).

Rozon, C., Lucotte, M., Davidson, R., Paquet, S., Oestreicher, J. S., Mertens, F., . . Romana, C. A. (2015). Spatial and temporal evolution of family-farming land use in the Tapajós region of the Brazilian Amazon. Acta Amazonica.

Rudel, T. K. (1998). Is There a Forest Transition? Deforestation, Reforestation, and Development1. Rural Sociology, 63(4), 533-552. doi: 10.1111/j.1549-0831.1998.tb00691.x

Soares-Filho, B., Rajão, R., Macedo, M., Carneiro, A., Costa, W., Coe, M., . . Alencar, A. (2014). Cracking Brazil's forest code. Science, 344(6182), 363-364.

Simmons, C. (2005). Territorializing land conflict: Space, place, and contentious politics in the Brazilian Amazon. GeoJournal, 64(4), 307-317. doi: 10.1007/s10708-005-5809-x

Valente, S. A. d. S., Valente, V. d. C., \& Fraiha Neto, H. (1999). Considerations on the epidemiology and transmission of Chagas disease in the Brazilian amazon. Memórias do Instituto Oswaldo Cruz, 94, 395-398.

Van Vliet, N., Mertz, O., Heinimann, A., Langanke, T., Pascual, U., Schmook, B., . . Leisz, S. (2012). Trends, drivers and impacts of changes in swidden cultivation in tropical forest-agriculture frontiers: A global assessment. Global Environmental Change, 22(2), 418-429.

Verner, D. (2004). Poverty in the Brazilian Amazon: An Assessment of Poverty Focused on the State of Pará: World Bank Policy Research Working Paper 3357.

ZEE. (2005). Extração Mineral Zoneamento Ecológico-Econômico da Rodovia BR-163 (Vol. Sócio Economia: Diagnóstico do Meio Socioeconômico e Jurídico). Brasilia. 